Florida International University FIU Digital Commons

$7-2-2015$

\title{
Investigation of the Lead Isotope Signatures of Marine Sediments in Relation to the Lead Isotope Signatures of Northern Andean Ores
}

Kimberly D. Beck

Florida International University, kbeck001@fiu.edu

DOI: $10.25148 /$ etd.FIDC000098

Follow this and additional works at: https://digitalcommons.fiu.edu/etd

Part of the Geochemistry Commons, and the Geology Commons

\section{Recommended Citation}

Beck, Kimberly D., "Investigation of the Lead Isotope Signatures of Marine Sediments in Relation to the Lead Isotope Signatures of Northern Andean Ores" (2015). FIU Electronic Theses and Dissertations. 2201.

https://digitalcommons.fiu.edu/etd/2201 


\section{FLORIDA INTERNATIONAL UNIVERSITY \\ Miami, Florida}

\section{INVESTIGATION OF THE LEAD ISOTOPE SIGNATURES OF MARINE SEDIMENTS}

IN RELATION TO THE

\section{LEAD ISOTOPE SIGNATURES OF NORTHERN ANDEAN ORES}

A thesis submitted in partial fulfillment of

the requirements for the degree of

MASTER OF SCIENCE

in

GEOSCIENCES

by

Kimberly D. Beck 
To: Dean Michael R. Heithaus

College of Arts and Sciences

This thesis, written by Kimberly D. Beck, and entitled Investigation of the Lead Isotope Signatures of Marine Sediments in Relation to the Lead Isotope Signatures of Northern Andean Ores, having been approved in respect to style and intellectual content, is referred to you for judgment.

We have read this thesis and recommend that it be approved.

Grenville Draper

Rosemary Hickey-Vargas

Andrew Macfarlane, Major Professor

Date of Defense: July 2, 2015

The thesis of Kimberly D. Beck is approved.

\begin{tabular}{r} 
Dean Michael R. Heithaus \\
College of Arts and Sciences \\
\\
\hline Dean Lakshmi N. Reddi \\
University Graduate School
\end{tabular}

Florida International University, 2015 


\author{
ABSTRACT OF THE THESIS \\ INVESTIGATION OF THE LEAD ISOTOPE SIGNATURES OF MARINE \\ SEDIMENTS IN \\ RELATION TO THE LEAD ISOTOPE SIGNATURES OF NORTHERN ANDEAN \\ ORES \\ by \\ Kimberly D. Beck
}

Florida International University, 2015

Miami, Florida

Professor Andrew Macfarlane, Major Professor

Lead isotope ratios of ores and igneous rocks in the Central and Southern Andes show a large-scale geographic pattern related to magmatic source processes. This pattern changes in the Northern Andes for reasons that are not well understood; this study is an investigation of potential causes of this change. Deep ocean sediment samples from the Nazca Plate were analyzed for ${ }^{206} \mathrm{~Pb} /{ }^{204} \mathrm{~Pb},{ }^{207} \mathrm{~Pb} /{ }^{204} \mathrm{~Pb}$ and ${ }^{208} \mathrm{~Pb} /{ }^{204} \mathrm{~Pb}$, and the data were compared with published data on central Andean ores and ores and igneous rocks from Ecuador. Lead isotopic compositions of the Nazca Plate sediments are quite homogenous and are a close match with Andean ore lead in the coastal arc from central Perú through south-central Chile. However, the lead isotope ratios of the sediment samples are much lower than northern Perú and Ecuador ores. Variations in sediment composition are probably not the source of the northern Andean ore lead isotope pattern. 


\section{TABLE OF CONTENTS}

CHAPTER

PAGE

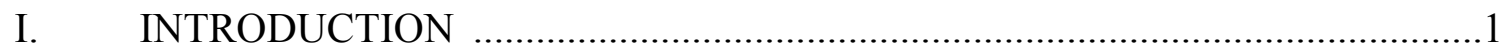

II. PREVIOUS RESEARCH ......................................................................

Geologic History of the Area .................................................................

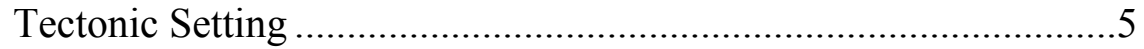

Stratigraphy .................................................................

Seafloor Age ................................................................ 10

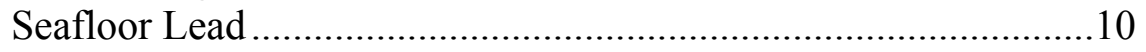

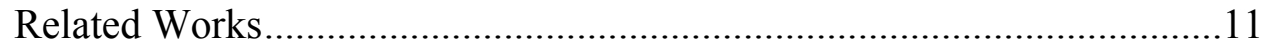

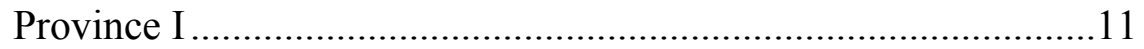

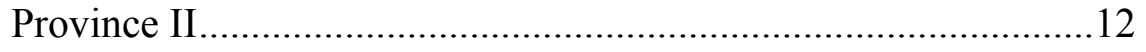

Province IIIa..................................................................... 12

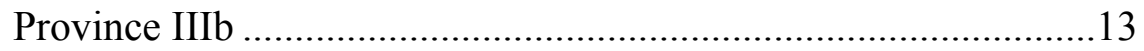

Province IV .................................................................. 13

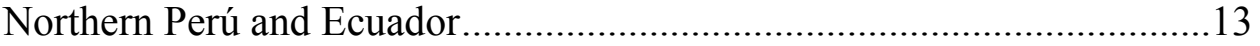

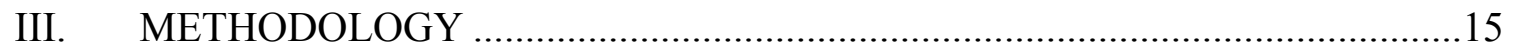

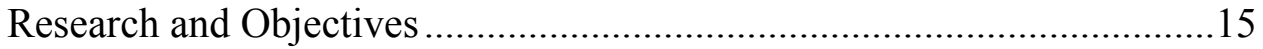

Sample Collection........................................................................ 15

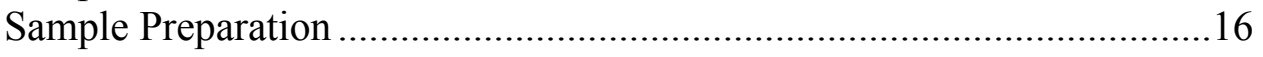

Sample Analysis...................................................................... 17

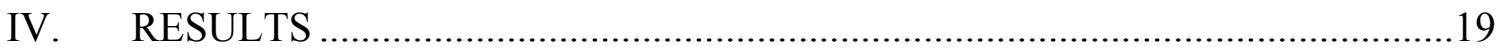

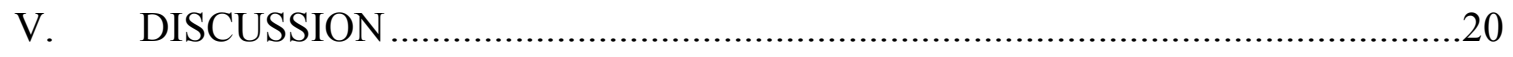

Lead Isotopic Composition of Nazca Plate Sediments ...........................20

Geographic Variability of Lead Isotope Ratios ...........................22

Variability of Lead Isotopes with Depth.....................................23

Comparison of Nazca Plate Sediments with Andean Lead Isotope

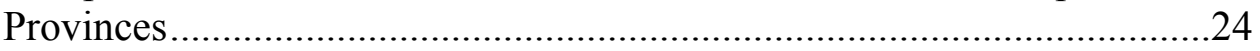

Comparison of Nazca Plate Sediments with Ecuador Ore Lead Isotope

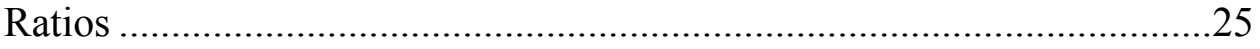

Implications for the Ecuadorian Ore Lead Isotope Trend .......................26

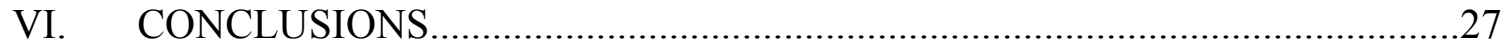

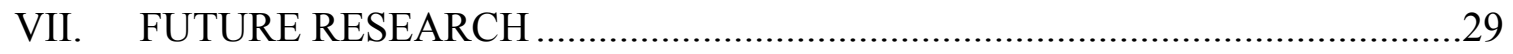


LIST OF REFERENCES...

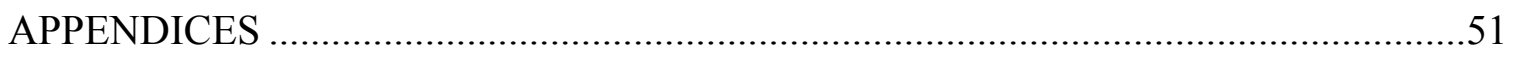




\section{LIST OF FIGURES}

FIGURE

PAGE

1. KNOWN DATA PLOTS FROM ECUADOR AND PERÚ ON MAP .30

2. PREVIOUS PERUVIAN DATA 31

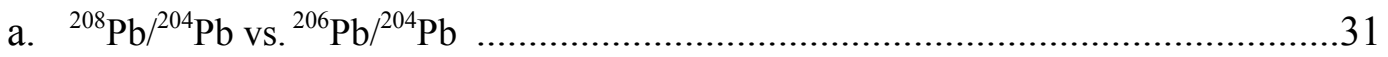

b. ${ }^{207} \mathrm{~Pb} /{ }^{204} \mathrm{~Pb}$ vs. ${ }^{206} \mathrm{~Pb} /{ }^{204} \mathrm{~Pb}$ 31

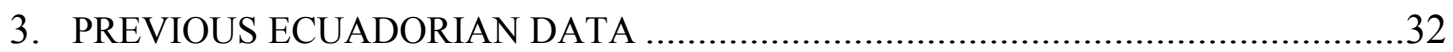

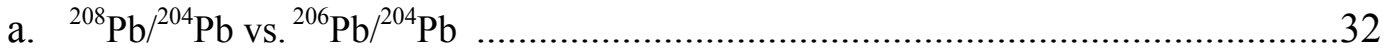

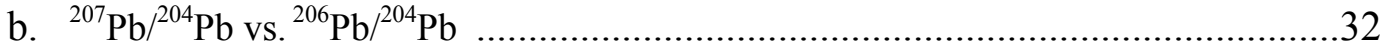

4. PREVIOUS ECUADORIAN DATA PLOTTED AGAINST MACFARLANE'S 2014

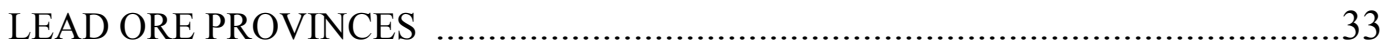

5. SAMPLE SITES FROM RISEPAC AND DOWNWIND EXPEDITIONS ANALYZED IN THIS STUDY

6. STRATIGRAPHIC SECTION OF THE AREA OF INTEREST

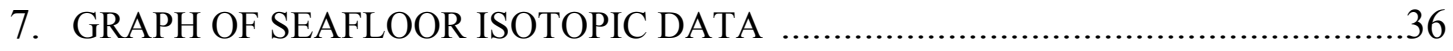

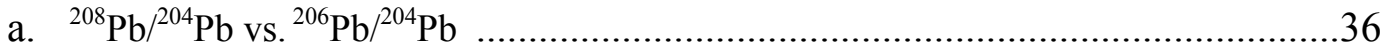

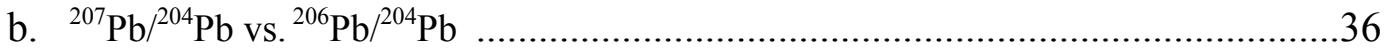

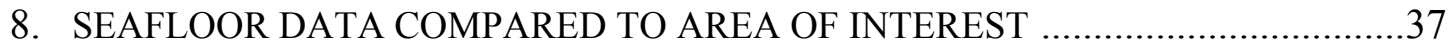

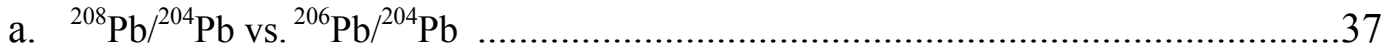

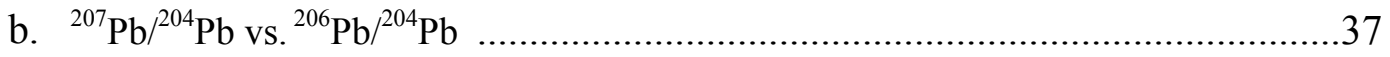

c. Seafloor data compared to Macfarlane's 2014 Lead Provinces ................................38

9. NEW SEAFLOOR DATA COMPARED TO KNOWN PACIFIC SEAFLOOR DATA

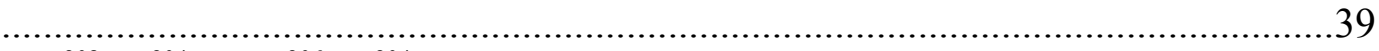

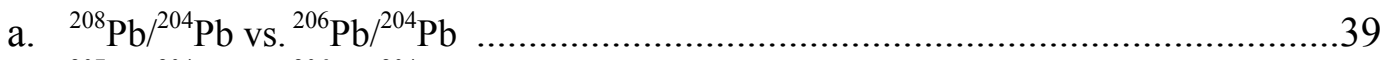

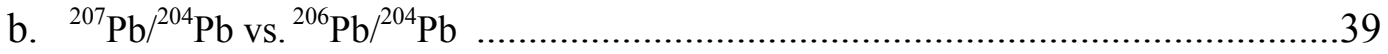

10. SEAFLOOR ISOTOPIC DATA PLOTTED BY DISTANCE FROM THE RIDGE .....40

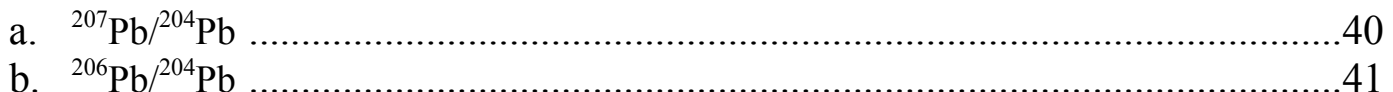


c. ${ }^{208} \mathrm{~Pb} / 204 \mathrm{~Pb}$

11. COMPARISON OF SEAFLOOR ISOTOPIC DATA BY DEPTH IN CORE .43

12. COMPARISON OF SEAFLOOR DATA BY SEDIMENT TYPE .44

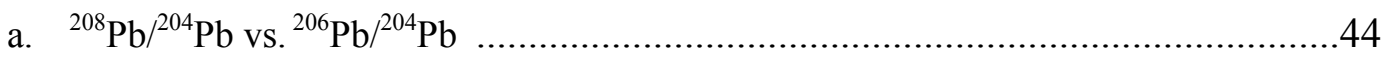

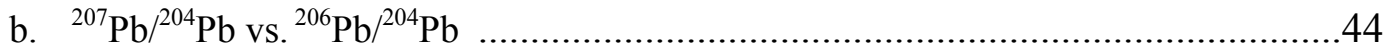

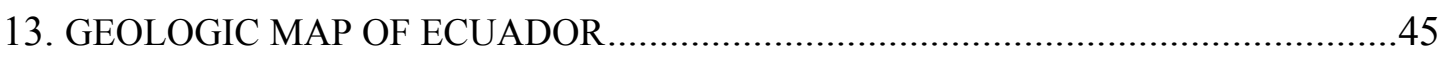

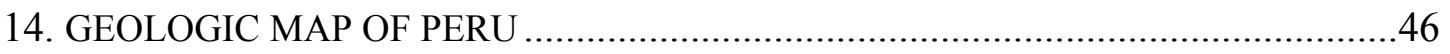




\section{INTRODUCTION}

Lead isotope ratios of ores and igneous rocks in the Central and Southern Andes show a large-scale geographic pattern related to magmatic source processes. Tertiary ores from Ecuador might be expected to show the same isotopic signatures seen in either the coastal or high Andes regions of Perú; instead, Ecuadoran ores have markedly higher ${ }^{206} \mathrm{~Pb} /{ }^{204} \mathrm{~Pb}$ relative to ${ }^{208} \mathrm{~Pb} /{ }^{204} \mathrm{~Pb}$ than either, and occupy an area of lead isotopic compositions that is very rare elsewhere in the Andes. This change could be the result of differences in the lead isotope ratios of sediments being subducted beneath Ecuador compared to those further south, which would change the initial composition of subduction-generated magmas (Harmon and Rapela, 1991). It could also result from differences in the lead isotopic composition of continental crust in Ecuador compared with Perú, or the amount of crustal assimilation and by subduction-generated magmas, or both, which would modify the lead isotopic signatures of the original magmas (Harmon et al, 1984). This study is an investigation of the possible effect of variations in the lead isotopic composition of subducted sediments on the compositions of Ecuadoran ores. Examination of the other potential sources of lead isotopic variability with be the subject of future research.

It is known that subducted sediments on the downgoing ocean floor can play a significant role in the lead budget of convergent boundary magmatic systems (Meijer, 1976; Dasch, 1981; White and Dupre, 1986; Peucker-Ehrenbrink et al., 1993 and Plank and Langmuir 1993). The available lead isotope database for Nazca Plate seafloor sediments has not been very large — a small number of analyses have been published from the Nazca Plate, and some of those are from the early 1960's and are of 
questionable reliability due to advances in technology. The present study focused on obtaining high-precision lead isotope ratio measurements on Nazca Plate sediments to see whether an explanation could be found in them for the changes in the lead isotope pattern in the Northern Andes. Deep ocean sediment samples collected from the Nazca Plate on sampling expeditions from 1957 to 1962 were processed and analyzed for ${ }^{206} \mathrm{~Pb} /{ }^{204} \mathrm{~Pb}$, ${ }^{207} \mathrm{~Pb} /{ }^{204} \mathrm{~Pb}$ and ${ }^{208} \mathrm{~Pb} /{ }^{204} \mathrm{~Pb}$, and their isotope ratios compared with possible sources including seafloor basalt, continental crust, and other data on marine sediments. New data on seafloor sediment were then compared with the existing database on central Andean ores and ores and igneous rocks from Ecuador.

The lead isotopic compositions of ores within the central and southern Andes Mountain range are fairly well-understood. Lead isotope ratios of ores and igneous rocks in Perú have been divided into four different zones or provinces (Figure1) on the basis of the lead isotopic compositions of these rocks (Gunnesch and Baumann, 1990; Macfarlane et al, 1990; Mukasa and Injoque-Espinoza, 1990 and Chiaradia et al, 2004, 2009). Figures 2 and 3 present the published lead isotope data on ores from Perú and Ecuador, respectively. Figure 4 shows the data for Ecuadoran ores plotted against the published ranges of lead isotope provinces in the Central Andes. Ores in Province I, hosted by rocks that are Jurassic to Tertiary in age, contain lead $(\mathrm{Pb})$ principally from mantle derived melt modified by the addition of subducted sediment to the mantle wedge (Macfarlane and Petersen 1990). Ores from Province II, hosted by rocks that are predominantly Jurassic and Cretaceous in age, are derived by mixing of lead from Province I type magmas and lead from and lead from the upper crustal host rock (Macfarlane and Petersen 1990). The ores of Province IIIa, hosted by rocks that are 
largely Paleozoic in age, are derived from crustal fusion and Permian rift-related volcanism (Gunnesch and Baumann, 1990 and Macfarlane et al, 1990). Province IIIb ores have high ${ }^{206} \mathrm{~Pb} /{ }^{204} \mathrm{~Pb}$ probably reflecting inputs of lead from low-grade metamorphic rocks ore sedimentary rocks derived from such basement. Province IV type ores are described as having their $\mathrm{Pb}$ isotopic composition strongly affected by the local, ancient high-grade metamorphic basement rock (Kamenov et al, 2002). The definition of these distinct provinces in Central and Southern Perú has uncovered an isotopic anomaly within the area of northernmost Perú and Ecuador.

It is expected that the lead isotopic ratios of the ores in the Ecuadorian Andes would follow the same trends as seen in Perú, with Province I type signatures near the coast and province II or IIIa type signatures inland; however, they have more radiogenic compositions than expected and have consistently higher values of ${ }^{208} \mathrm{~Pb} /{ }^{204} \mathrm{~Pb}$ plotted against ${ }^{206} \mathrm{~Pb} /{ }^{204} \mathrm{~Pb}$. The Ecuadoran ores plot consistently within the range of ore lead province IIIb, which is an isotopic signature seen in less than $5 \%$ of the ore deposits in the central and southern Andes. This suggests that ore lead sources in Ecuador differ fundametally from those further south. Hypotheses to explain divergence include, 1) the relatively young age of the subducting Nazca Plate, led to subduction of younger sediment and enrichment of subcontinental mantle through mixing of pelagic sediment and sedimentary basement rock (Mukasa and Injoque-Espinoza, 1990); 2) different lead isotopic composition of the arc basement in Ecuador compared to Perú; 3) interaction of Ecuadorian arc magmas with upper crustal rocks like those thought to cause Province IIIb in the central Andes; 4) the Ecuadorian subduction of the Carnegie Ridge has been shown 
(Bourdon et al., 2003) to be a controlling factor in the distribution and composition of volcanic activity in the area and could affect the isotopic systematics of coastal Ecuador.

The this study examines the lead isotope ratios of seafloor sediments to see whether variations in sediment composition could explain why the ore lead isotope patterns observed in Ecuador are so different from those further south. 


\section{PREVIOUS RESEARCH \\ Geologic History of the Area}

\section{Tectonic setting}

The Andes Mountains are the longest continental mountain range in the world. They extend the length of the western coast of South America and extend from north to south through seven South American countries: Venezuela, Colombia, Ecuador, Perú, Bolivia, Chile and Argentina (Atherton et al., 1985). Tectonically, the area around the Andes is composed of the South American Plate, Nazca Plate, Pacific Plate, Cocos Plate and Antarctic Plate (Maksymowicz et al., 2012). The eastern-most edge of the Nazca Plate is subducting below the South American Plate, causing the formation of the PerúChile Trench. The Nazca Plate has divergent boundaries with the Antarctic Plate, which produces the Chile Rise and with the Cocos Plate, forming the Galapagos Rise. The contact with the Pacific Plate is also divergent, forming the East Pacific Rise.

The Peruvian Andes are divided into two belts, the Eastern and Western cordilleras. The Eastern Cordillera was formed in the Mesozoic but its composition is primarily Proterozoic schists and Paleozoic sediment (Atherton et al., 1985). The Western Cordillera is Tertiary in age and composed of crystalline basement, shelf sediment, Mesozoic volcanics and Mesozoic sediments (Atherton et al., 1985). The Perú -Chile Trench (also known as the Atacama Trench) is located 160 kilometers off the coast of Perú and Chile; it is the longest oceanic trench, at 5,900 kilometers long and has a maximum depth of 8,065 meters. The trench represents where the Nazca Plate meets (and is subducted under) the South American Plate. 
The Nazca Plate (also referred to as a slab) is oceanic crust, which is denser than continental crust and so is being subducted beneath the more buoyant South American continental plate (Capitanio et al., 2011 and Daly, 1989). The relatively young age of the plate causes it to have a comparatively low density while still being slightly buoyant. When a slab is younger in age it undergoes deformation under a larger range of temperature and pressure compared to an older slab. Therefore a younger slab shows less resistance to bending resulting in a shallow angle of subduction (Van Hunen and N.J. Vlaar, 2002). Thickened crust on an aseismic ridge, a high overriding plate and high mantle viscoscity can cause extra compositional buoyancy, this buoyancy inhibits the suction and sinking of the slab into the mantle (Van Hunen and N.J. Vlaar, 2002). Instead of being subducted at a steep angle, moving towards the subduction zone and generating magma, the shallow angle of subduction causes the slab to wedge under and flatten beneath the overlying plate without melting, this shallow angle subduction phenomenon is referred to as flat slab subduction (Wollard and Klum, 1981).

Flat-slab subduction generally occurs at an angle of less than $30^{\circ}$ (Atherton et al., 1985). A flat slab can sometimes extend for hundreds to over a thousand kilometers (Atherton et al., 1985). Considering that the subduction of slabs is necessary to drive subduction zone volcanism, flat-slab subduction can sometimes be used to help explain gaps of volcanic activity in arc systems (Daly, 1989). Flat slab subduction is currently occurring beneath parts of the Andes causing segmentation of the Andean Mountain chain (Doe, 1970). There are two major areas within the Andes where this shallow subduction occurs: the largest area is located between $3^{\circ} \mathrm{S}$ and $15^{\circ} \mathrm{S}$, spanning central and 
northern Perú, and the other region is beneath central Chile and Argentina between $28^{\circ} \mathrm{S}$ and $33^{\circ} \mathrm{S}$ (Martinod et al., 2010).

Although there has been subduction along this plate boundary since the Jurassic, the actual uplift of the Andes Mountains is relatively young in age, taking place in the Late Cretaceous (Martinod et al., 2010). The South American crust has been deformed and thickened by the convergence, creating the Andes Mountains. Melting of the rocks surrounding the subducting slab has led to volcanism; many of the Andes' tallest peaks are volcanoes (Capitanio et al., 2011). The Andes Mountain range extends for an expansive 5,000 km or more, and contains one of the world's largest active plate boundary zones (Lamb et al., 1997).

\section{Stratigraphy}

Coastal Perú is underlain by rocks identified to be metamorphic, volcanic or plutonic in origin. These rocks are a substantial difference from the rocks that are underlying Ecuador. The rocks within the foundation of coastal Ecuador are composed of a belt of rocks that are interpreted to be pieces of oceanic crust (Wollard and Klum, 1981). The late Paleocene/Eocene Andean orogeny can be seen offshore in a distinct relationship of seismic velocity within the Salaverry Basin where, after the event, there has been an accumulation of Cenozoic marine sedimentation (Wollard and Klum, 1981). The upper slope of the Trujillo Basin, however, shows a more constant sedimentation rate with representations from the early Tertiary. The Trujillo Basin is overlain with a $4 \mathrm{~km}$ thick layer of sediment that is Paleogene in age, while the upper-slope Lima Basin is blanketed with $2 \mathrm{~km}$ of material that is late Miocene or younger in age (Wollard and Klum, 1981). Post-Oligocene tectonics caused a series of uplift and deformation events 
within the Trujillo Basin which resulted in a drastic reduction of sedimentation in the immediate area (Wollard and Klum, 1981).

Composed mostly of Mesozoic to Tertiary age igneous rocks, some portions of the Ecuadorian Andes rest on older rock (Lebras et al., 1987). In coastal areas and the Western Cordillera there are widespread outcrops of Cretaceous to Eocene volcanic and plutonic rocks with a basic to intermediate composition (Lebras et al., 1987). The coastal rocks of Ecuador consist of three collections of rock types (Feininger and Bristow, 1980). These three groupings are the Piñon and San Lorenzo Formations, the Celica Formation, and the Macuchi Formation. The Piñon Formation is heavily composed of pillow lavas that range from aphyric to porphyritic in texture. The pillow lavas tend to contain phenocrysts of plagioclase and augite which are found within a plagioclase, clinopyroxine and Fe-Ti oxide matrix (Lamb et al., 1997). The other major component of the Piñon Formation is massive dolerite deposits formed into complex dike and sill structures (Lamb et al., 1997). The dolerites are compositionally the same as the pillow lavas, but have a fine-grained ophitic texture (Lamb et al., 1997). The Piñon Formation (Figure 3), in particular, is considered by Feininger and Bristow (1980) to be a segment of the ocean floor. The

San Lorenzo Formation is chemically very similar to the Piñon Formation; both are composed of the same rock types, but because of a difference in age, they are determined to be separate formations (Feininger and Bristow 1980). Like the Piñon Formation, the San Lorenzo Formation is composed of pillow basalts and dikes and sills of dolerite (Feininger and Bristow 1980). There are also basaltic dikes and sills in the San Lorenzo Formation, and the rocks within this formation are less metamorphosed and 
hydrothermally altered than those found within the Piñon Formation (Feininger and Bristow 1980).

The Macuchi Formation includes lavas that range from fine-grained basalt to porphyritic dacite, volcaniclastic rocks, tuffs, and some fine-grained sedimentary rocks (Lebras et al., 1987). The basalts and dacites are composed of plagioclase and augite, with a variety of accessory minerals (Lebras et al., 1987). The Macuchi Formation (Figure 3) also contains pieces of mid-oceanic ridge basalt ophiolites that were trapped within the suture zone between the Macuchi Island Arc and the continent (Lebras et al., 1987). The Celica Formation is composed of rocks that are part of the intracontinental arc within northwest Perú and southwest Ecuador and is comprised of lava and pyroclastic flows (Feininger and Bristow 1980). The rocks in the Celica formation are of andesitic composition and have been affected by zeolite and greenschist facies metamorphism (Feininger and Bristow 1980).

There were two major events that took place in Ecuador: the accretion of the Macuchi Formation and the accretion of the Piñon Formation (Wollard and Klum,, 1981). During these events, large pieces of oceanic crust were obducted onto continental crust which extended the continental edge seaward. The accretionary process is able to occur because the buoyancy of the oceanic basalt plateaus allows it to avoid being subducted. These accretion events are believed to have been caused by activities such as subduction spanning early Cretaceous through Eocene Late Cretaceous, Alpine-style thrusting and Oligocene collision (Wollard and Klum, 1981). 


\section{Seafloor age}

The seafloor off the western coast of South America, north of $40^{\circ}$, is spreading at a rate of $7-9 \mathrm{~cm}$ per year. The ages of the seafloor in the area, however, have a large range of variation. From $10^{\circ} \mathrm{S}$ northward, the age of the seafloor ranges from $30 \mathrm{Ma}$ to $12 \mathrm{Ma}$, whereas south of this point the age ranges $56-60 \mathrm{Ma}$; this puts the difference in age of the seafloor that is being subducted beneath the South American plate to be as much as $48 \mathrm{Ma}$ in certain areas. This difference in age could potentially emplace different formations within localities at different periods of time, altering the compositional makeup of magmas and ores.

\section{Seafloor lead}

Genesis of magma is a topic that has been widely studied by various scientists for many years. In these studies there has been interest in the role that marine sediment plays in the geochemical isotopic signatures of magmas found in areas of subduction. Multiple studies have been conducted; Meijer (1976), Dasch (1981), White and Dupre (1986), Peucker-Ehrenbrink et al., (1993), and Plank and Langmuir (1993) that have looked directly at the possibility of subducted pelagic sediment contribution in the processes of magma generation. White and Dupre (1985) determined that the subduction of pelagic sediment was likely responsible for the change in isotopic composition on their study site in the Lesser Antilles. They point out that the subduction of the pelagic sediment is aiding in the destruction of the continental crust in the area (White and Dupre, 1985). The current lack of accretionary presence in northern Perú and Ecuador suggests that this view on sediment subduction could also help to explain the radiogenic $\mathrm{Pb}$ in the area of interest. 
Chow and Patterson (1962) published the mean isotopic ratio of lead contained in sea-floor sediment. Chow and Patterson (1962) determined that the majority of lead that is found within seafloor sediments has been deposited through the precipitation of dissolved lead found in seawater. It has been shown that the major sources for this lead are as follows: 1) erosion of terrestrial sediment; 2) introduction through hydrothermal venting; 3) manganese nodules; 4) exhalation of volcanic ash (Chow and Patterson, 1962; Reynolds and Dasch, 1971; Miller et al., 1994).

\section{Related Works}

Previous studies have focused on the Central Peruvian Andes and are in the same regional locality. Gunnesch and Baumann (1990) and Macfarlane et al, (1990) narrowed the isotopic signatures of surrounding areas into four main groups. Both groups saw a general trend that the systematic radiogenic isotope signatures increased as they moved from the westward coastline inland toward the Andes. These isotopic signatures plot in such a way that Gunnesch and Baumann (1990) and Macfarlane and Petersen (1990) were able to divide the areas into specific provinces.

\section{Province I}

Macfarlane et al, (1990) described Province I running along the coast of Chile and Perú and extend into the Western Cordillera. The area is composed of coastal and volcanic arc sediment deposited on to a basement of Mesozoic and Paleozoic sedimentary and metamorphic rock (Macfarlane and Petersen 1990). Province I lead has been found (Macfarlane and Petersen, 1990) to range in age from Jurassic to early Tertiary. The isotopic signatures of lead in this area plot within the range of ${ }^{206} \mathrm{~Pb} /{ }^{204} \mathrm{~Pb} 18.21$ to 18.82 , ${ }^{207} \mathrm{~Pb} /{ }^{204} \mathrm{~Pb} 15.55$ to 15.69 and ${ }^{208} \mathrm{~Pb} /{ }^{204} \mathrm{~Pb} 38.11$ to 38.95 (Macfarlane and Petersen, 
1990) which corresponds to the known isotopic composition of orogenic lead (Zartman and Doe 1981 and Macfarlane and Lechtman 2014). Macfarlane and Petersen (1990) and Gunnesch et al. (1990) teams determined that the isotopic signatures found in the rocks of Province I derived from mixing of crustal rock melt and the magmatic source.

\section{Province II}

Province II lies along the high Andean arc and is composed of limestones, siltstones, and shales that have been affected by folding and faulting (Macfarlane and Petersen, 1990). The isotopic signatures of the lead in this area contained ${ }^{206} \mathrm{~Pb} /{ }^{204} \mathrm{~Pb}$, ${ }^{208} \mathrm{~Pb} /{ }^{204} \mathrm{~Pb}$ and ${ }^{207} \mathrm{~Pb} /{ }^{204} \mathrm{~Pb}$ ranges that were higher than those found within Province I. It was determined that this area was also derived from mixing of magma and host rock melt (Macfarlane and Petersen, 1990).

\section{Province IIIa}

The area described by Macfarlane et al, (1990) as Province IIIa includes the Eastern Cordillera extending into the Altiplano region. Province IIIa is underlain by shales, sandstones and siltstones that are Paleozoic in age and have been affected by two distinct episodes of magmatism (Macfarlane and Petersen 1990). The isotopic signatures of the lead in this area contained ${ }^{206} \mathrm{~Pb} /{ }^{204} \mathrm{~Pb} 17.97$ to $25.18,{ }^{208} \mathrm{~Pb} /{ }^{204} \mathrm{~Pb} 15.51$ to 16.00 and ${ }^{207} \mathrm{~Pb} /{ }^{204} \mathrm{~Pb} 37.71$ to 40.07 . The values from Macfarlane et al, (1990) study are consistent with those of Gunnesch and Baumann (1990) that the isotopic signature grows more radiogenic moving inland. Macfarlane et al, (1990) and Gunnesch and Baumann (1990) believed that continental crust fusion and Permian rift-related volcanism could be related to the readings in Province IIIa. 


\section{Province IIIb}

Province IIIb type ores differ greatly from those found in Province IIIa and are characterized by high ${ }^{206} \mathrm{~Pb} /{ }^{204} \mathrm{~Pb}$ relative to ${ }^{208} \mathrm{~Pb} /{ }^{204} \mathrm{~Pb}$ and ${ }^{207} \mathrm{~Pb} /{ }^{204} \mathrm{~Pb}$ values. Province IIIb is the only one thus far that is not defined by geographic location. The significantly more radiogenic leads found in Province IIIb suggest a source of lead that has not been seen yet in the other provinces. The isotopic signature that is found in the Province IIIb ores is suggested (Macfarlane and Lechtman 2014) to have had interference from metamorphic basement rocks that have high ${ }^{206} \mathrm{~Pb} /{ }^{204} \mathrm{~Pb}$. Macfarlane and Lechtman (2014) suggests that there is a presence of small regions that contain Paleozoic sedimentary and metamorphic basement rock within the continental crust material, resulting in the placement of these Province IIIb type ores.

\section{Province IV}

Province IV is described by Kamenov et al, (2002) as extending through Perú and into Bolivia. Macfarlane found the Province IV samples to be isotopically influenced by the regional metamorphic basement rock. Province IV samples can be divided into two sub-categories, Provinces IVa and IVb. The division between Province IVa and IVb is determined by the ages and isotopic differences within the samples; Province IVa samples are found to be Paleocene in age, where Province IVb samples are Miocene in age. (Kamenov et al., 2002).

\section{Northern Perú and Ecuador}

The study area extends from northernmost Perú into Ecuador. The lead isotopic characteristics of Province IIIb, with high ${ }^{206} \mathrm{~Pb} /{ }^{204} \mathrm{~Pb}$ at moderate ${ }^{208} \mathrm{~Pb} /{ }^{204} \mathrm{~Pb}$, occur in a relative handful of ore deposits in the central and southern Andes, but they are the 
dominant signature in ore deposits from Ecuador and are also seen in a few deposits in northernmost Perú. My study is an examination of one possible explanation for this difference. In addition to continental crust, the Ecuadorian Andes contain Jurassic to Eocene accreted oceanic crust and oceanic arc rocks which are not seen further south and present another possible explanation (Chiaradia et al., 2004). 


\section{METHODOLOGY}

\section{Research and Objectives}

Sediment samples were analyzed to determine if seafloor that is subducting under northern Perú and Ecuador is having a direct effect on the lead isotopic ratios observed in rocks and ores in this area. The samples used in this analysis are from the oceanic plates adjacent to northern Perú and Ecuador to meaningfully compare with their isotopic signatures. The new seafloor data have been compiled and compared to existing continental data from the northern Andes and that of surrounding areas. Trends in the regional lead isotope data were analyzed and compared with new data in order to evaluate the origin of the isotopic "anomaly" in $\mathrm{Pb}$ from ores and rocks. My goal is to provide an innovative insight into the sources of rocks and ores in northern Perú and Ecuador, and in doing so, also constrain the origin of anomalous isotopic trends here.

\section{Sample Collection}

Oceanic sediment samples were originally collected during the Risepac and Downwind Expeditions that took place in 1961-1962 and 1957-1958, respectively. The expeditions aimed to study the isotopic content of the deep ocean sediment and they focused their study in the northeast portion of the South Pacific Ocean. The Risepac Expedition was a three month expedition out of the Scripps Institute of Oceanography. The Expedition was put forth by geophysicist Richard Von Herzen to study the flow of heat from the Earth's interior through ocean floor sediments. Accessory studies were also conducted on the magnetic anomalies on the rise (California, U., 1961). The Downwind Expedition was a two month cruise also conducted through Scripps Institute of Oceanography and focused on investigating the topography, crustal structure and heat 
flow of the East Pacific Rise. Smaller studies were conducted to study the geochemistry and biology of the area (Fisher 1958). The samples used for the present study were taken through gravity and piston core sampling during these two expeditions and stored at the Scripps Oceanographic Institution at the University of California (Figure 5). Andrew Macfarlane retrieved and catalogued the samples for this study in July of 1992. The samples have been stored at Florida International University under the care of Andrew Macfarlane in preparation for analysis.

\section{Sample Preparation}

Thirty-five samples from the Nazca, Pacific and Antarctic plates were processed for the current research. Samples were double bagged and crushed using a rock hammer and weighed. About $500 \mathrm{mg}$ of each sample was used for analysis. Samples were dissolved in 3:2 $\mathrm{HF}: \mathrm{HBr}$ (some samples exhibited a strong, violent reaction suggesting an abundance of organic materials) and dried on a hot plate. Next, $0.5 \mathrm{~mol} 2$ bottle (2B) $\mathrm{HBr}$ was added to the samples while thoroughly rinsing down the sides of the vial and samples were redried on a hot plate. This process was repeated a total of three times. The $0.5 \mathrm{~mol}$ 2B HBr solution was again added to the sample, filling $1 / 3$ of the vial. Samples were ultrasonicated for a total of 15 minutes in 5 minute increments. The ultrasonicated liquid was titrated into test tubes; this process was repeated for a total of three times. Test tubes containing the samples were placed into a centrifuge and run for 6-10 minutes, rotated $180^{\circ}$ and run for an additional 6-10 minutes. Next, samples were passed through cleaned and conditioned lead columns and allowed to drip through resin that stored the lead until the collection process. During collection, $\mathrm{HNO}_{3}$ was added to the drip to release this stored lead. The samples were dried to a small droplet and reconstituted. The drip 
process was repeated with the newly reconstituted sample. The samples were dried on a hot plate one final time to $\sim 1 \mathrm{~mm}$ in diameter and stored in Teflon beakers that have been thoroughly cleaned through acid washing and rinsed with deionized water, corning water, quartz water and 2B water and stored in a clean laboratory for later analysis in the mass spectrometer. Samples were be stored in this way to prevent isotopic contamination. Six samples of $208 \mathrm{~Pb}$-enriched spike were processed through the entire chemistry to monitor blank levels.

\section{Sample Analysis}

Processed samples were transported to Gainesville, Fl. for further analysis in a multi-collector inductively-coupled-plasma mass spectrometer that is operated at the University of Florida by George Kamenov in the Department of Geology. Lead isotopic ratios were measured at the Department of Geological Sciences, University of Florida using a "Nu-Plasma" multiple-collector inductively-coupled-plasma mass spectrometer (MC-ICP-MS). Samples were wetted with a $2 \% \mathrm{HNO}_{3}$ solution and allowed to sit. Then 1000 microliters of the sample solution was placed into a plastic beaker with 20-30 milliliters of $2 \% \mathrm{HNO}_{3}$. The beaker was taken to the mass spectrometer where a thin plastic tube transferred the sample into the ICP-MS. Voltage was measured by a computer, once the reading showed 3-6 volts the run was started for the sample. After completion of each sample the tube was placed into a prewash solution for 30 seconds and a washing solution for 60 seconds to assure no cross contamination of samples. The remnant of the dilute sample was discarded and the beaker was rinsed three times in 4times distilled water to clean it before the next use. After the completion of all 36 
samples, $6{ }^{208} \mathrm{~Pb}$ spikes and 3 NBS 981 standards, all remaining sample material was repacked and data were retrieved and recorded for all samples.

In an ICP-MS, argon gas is used to form the inductively-coupled plasma ion source that consists of electrons, neutrons and neutral ions. The argon gas is used to super-heat the elements that are contained in a given sample to $7000^{\circ} \mathrm{K}$ and atomize them. Once the ions are atomized, they are moved through cones of varying sizes by a magnetic force produced from a radio frequency. The magnetic force is produced when the frequency is passed through a tightly wound coil. The atomized ions pass into a highly vacuumed chamber through the magnetic field and are dispersed on the basis of their mass-to-charge ratio. These mass-resolved ions are then directed into collectors and converted to voltage. Comparison of voltages corresponding to individual ion beams will yield peaks. The peak is then measured and relates to the amount of elemental isotope that is contained in the sample. Lead isotopic analyses were conducted using Tl normalization technique on fresh mixtures to prevent oxidation of thallium to $\mathrm{Tl} 3+$, details provided in Kamenov et al. (2004). Analyses of NBS 981 were conducted along with the sample analyses and the ocean plate sediment samples gave the following results: ${ }^{206} \mathrm{~Pb} /{ }^{204} \mathrm{~Pb} 18.574$ to $18.772,{ }^{207} \mathrm{~Pb} /{ }^{204} \mathrm{~Pb} 15.559$ to 15.644 , and ${ }^{208} \mathrm{~Pb} /{ }^{204} \mathrm{~Pb}$ 38.246 to 38.759 . 


\section{RESULTS}

A brief description of samples are given in Appendix I, sample data are given in Appendix II and pictures of smear slides taken of each sample using a Nikon microscope at 50 times magnification in both plain polarized light and crossed polarized light are located in Appendix III. In this study 36 seafloor samples from the Nazca, Antarctic and Pacific plates samples were analyzed; 8 samples of red clay, 14 samples of green to dark brown clay, 3 samples of green to brown mud, 9 samples of biogenic clay/ooze, one sample of sandy silt and one sample that was undescribed. The sediments deposited over the Nazca, Antarctic and Pacific plates have lead isotopic compositional ranges as follows: ${ }^{206} \mathrm{~Pb} /{ }^{204} \mathrm{~Pb} 18.574$ to $18.772,{ }^{207} \mathrm{~Pb} /{ }^{204} \mathrm{~Pb} 15.559$ to 15.644 , and ${ }^{208} \mathrm{~Pb} /{ }^{204} \mathrm{~Pb}$

38.246 to 38.759. Data for these sediments are plotted for their ${ }^{206} \mathrm{~Pb} /{ }^{204} \mathrm{~Pb}$ and ${ }^{208} \mathrm{~Pb} /{ }^{204} \mathrm{~Pb}$ values in Figure $7 \mathrm{a}$ and their ${ }^{206} \mathrm{~Pb} /{ }^{204} \mathrm{~Pb}$ and ${ }^{207} \mathrm{~Pb} /{ }^{204} \mathrm{~Pb}$ values in Figure $7 \mathrm{~b}$. Analyses of the total chemistry blanks showed contamination ranging from 48 to $298 \mathrm{pg}$, and five of the six blanks were $\leq 102 \mathrm{pg}$. Therefore, correction for the blank contamination can be safely ignored for samples likely containing at least $500 \mathrm{mg}$ of lead. There is a comparison of the data from northern Perú and Ecuador to the new seafloor sediment data that were collected in the present study in Figure 8. Figure 9 shows a comparison of the known Ecuadorian and northern Peruvian rock and ores data plotted with the new sediment data taken from Nazca, Antarctic and Pacific plates. 


\section{DISCUSSION}

\section{Lead Isotopic Composition of Nazca Plate Sediments}

The compositions of Nazca Plate sediment samples analyzed for this study are compared in Figure 9 with published data on Nazca Plate Mid Ocean Ridge Basalt [MORB] (Unruh and Tasumoto, 1976), manganese nodules (Reynolds and Dasch, 1971), previous analyses of Pacific seafloor sediments (Chow and Patterson, 1962; Dasch, 1981; Peucker-Ehrenbrink et al., 1994. Also shown are lead evolution curves from the commonly-cited models of Stacey and Kramers (1975) and Doe and Zartman (1981). The seafloor sediment samples from the present study have values of ${ }^{206} \mathrm{~Pb} /{ }^{204} \mathrm{~Pb} 18.574$ to 18.772, ${ }^{207} \mathrm{~Pb} /{ }^{204} \mathrm{~Pb} 15.559$ to 15.644 , and ${ }^{208} \mathrm{~Pb} /{ }^{204} \mathrm{~Pb} 38.246$ to 38.759 . The MORB data from Unruh and Tasumoto (1976) are ${ }^{206} \mathrm{~Pb} /{ }^{204} \mathrm{~Pb} 18.558$ to $18.774,{ }^{207} \mathrm{~Pb} /{ }^{204} \mathrm{~Pb} 15.502$ to 15.536, and ${ }^{208} \mathrm{~Pb} /{ }^{204} \mathrm{~Pb} 38.077$ to 38.216 . Comparison of the new sea floor sediment samples to previously published MORB data shows that the MORB produces lower values of ${ }^{208} \mathrm{~Pb} /{ }^{204} \mathrm{~Pb}$ than what is found in the sediment samples, not entirely surprising considering that MORB's are generally depleted.

When the new sediment samples are compared to the manganese nodules (Reynolds and Dasch, 1971), there is a very strong correlation of the isotopic content. The manganese nodules have isotopic values from: ${ }^{206} \mathrm{~Pb} /{ }^{204} \mathrm{~Pb} 18.676$ to 19.089 , ${ }^{207} \mathrm{~Pb} /{ }^{204} \mathrm{~Pb} 15.601$ to 15.648 , and ${ }^{208} \mathrm{~Pb} /{ }^{204} \mathrm{~Pb} 38.576$ to 39.127 and the data from the present study shows values from: ${ }^{206} \mathrm{~Pb} /{ }^{204} \mathrm{~Pb} 18.574$ to $18.772,{ }^{207} \mathrm{~Pb} /{ }^{204} \mathrm{~Pb} 15.559$ to 15.644, and ${ }^{208} \mathrm{~Pb} /{ }^{204} \mathrm{~Pb} 38.246$ to 38.759 . The data fields plot very closely together in Figure 9, suggesting that the sediment is acquiring some of the isotopic signature from this source. Dash (1981) Nazca Plate sediment samples have isotopic compositions that 
are similar to the seafloor sediment samples from the present study. The Nazca Plate samples range in isotopic composition from: ${ }^{206} \mathrm{~Pb} /{ }^{204} \mathrm{~Pb} 18.123$ to $18.716,{ }^{207} \mathrm{~Pb} /{ }^{204} \mathrm{~Pb}$ 15.472 to 16.640 , and ${ }^{208} \mathrm{~Pb} /{ }^{204} \mathrm{~Pb} 38.796$ to 38.863 and the seafloor sediment samples range in isotopic composition from: ${ }^{206} \mathrm{~Pb} /{ }^{204} \mathrm{~Pb} 18.574$ to $18.772,{ }^{207} \mathrm{~Pb} /{ }^{204} \mathrm{~Pb} 15.559$ to 15.644, and ${ }^{208} \mathrm{~Pb} /{ }^{204} \mathrm{~Pb} 38.246$ to 38.759. A small portion of Dasch (1981) Nazca sediment data from correlate very strongly with the data analyzed in this study, however a large portion falls into a range that is significantly less radiogenic than the new seafloor sediment samples.

The data range for the Peucker-Ehrenbrink et al., (1994) Pacific pelagic sediment is very large and it extends into fields that are both more radiogenic and less radiogenic than the samples analyzed in the present study. Data from these Pacific Ocean pelagic sediments are as follows: ${ }^{206} \mathrm{~Pb} /{ }^{204} \mathrm{~Pb} 18.279$ to $19.284,{ }^{207} \mathrm{~Pb} /{ }^{204} \mathrm{~Pb} 15.506$ to 15.687 , and ${ }^{208} \mathrm{~Pb} /{ }^{204} \mathrm{~Pb} 37.904$ to 38.955 and the samples in this study are: ${ }^{206} \mathrm{~Pb} /{ }^{204} \mathrm{~Pb} 18.574$ to $18.772,{ }^{207} \mathrm{~Pb} /{ }^{204} \mathrm{~Pb} 15.559$ to 15.644 , and ${ }^{208} \mathrm{~Pb} /{ }^{204} \mathrm{~Pb} 38.246$ to 38.759 . The Pacific data from Chow and Patterson (1962) have the strongest discrepancy in isotopic content from that found in the new seafloor sediment that was analyzed in the present study. The data reported by Chow and Patterson (1962) are strongly radiogenic, having isotopic ratios of ${ }^{206} \mathrm{~Pb} /{ }^{204} \mathrm{~Pb} 19.980$ to 17.320 and ${ }^{208} \mathrm{~Pb} /{ }^{204} \mathrm{~Pb} 41.260$ to 37.571 compared to the ${ }^{206} \mathrm{~Pb} /{ }^{204} \mathrm{~Pb} 18.574$ to 18.772 and ${ }^{208} \mathrm{~Pb} /{ }^{204} \mathrm{~Pb} 38.246$ to 38.759 ratios that are seen in the present study.

The known seafloor data did show a trend that was slightly less radiogenic when compared to the seafloor sediments that were analyzed herein. The oceanic plate samples that were analyzed in this study fall right along the endmember of Stacey-Kramers curve 
(Figure 7a). When plotted against the Doe-Zartman curve, the samples corresponded most closely with the Orogene portion of the curve (Figure 7a), this particular curve is known to represent lead ratios that are representative of orogenic background.

\section{Geographic variability of lead isotope ratios}

A trend was noticed within the samples, 8 samples; DWHG 79 \#1, DWHG 79 \#2, DWHG $56 \# 1$, DWHG 56 \#2, DWHG 56 \#3, DWHT G54, DWHT G54R and RIS 52G grouped together with ${ }^{206} \mathrm{~Pb} /{ }^{204} \mathrm{~Pb} 18.574$ to 18.622 and ${ }^{208} \mathrm{~Pb} /{ }^{204} \mathrm{~Pb} 38.246$ to 38.448 , less radiogenic reading on a plot of ${ }^{206} \mathrm{~Pb} /{ }^{204} \mathrm{~Pb}$ and ${ }^{208} \mathrm{~Pb} /{ }^{204} \mathrm{~Pb}$ values, as seen in Figure 5, all 8 of these samples can be found on the Western edge of the Nazca plate, with one crossing over the East Pacific Rise onto the Pacific plate. Isotope ratios of the samples were graphed (Figure $10 \mathrm{a}-\mathrm{c}$ ) versus the spreading ridge (samples were measured from the ridge in the direction of spreading). Figure 10a is a graph that compares ${ }^{207} \mathrm{~Pb} /{ }^{204} \mathrm{~Pb}$ ratio with distance to the spreading ridge, this graph shows a trend of isotopic content decreasing in radiogenic content as you approach the spreading ridge, there is one point of discontinuity with this overall trend and it lies around 500,000 meters from the spreading ridge. This discontinuity represents samples that are located on the Antarctic plate.

Figure $10 \mathrm{~b}$ is a graph that compares ${ }^{206} \mathrm{~Pb} /{ }^{204} \mathrm{~Pb}$ ratio with distance to the spreading ridge, this graph shows less consistency of isotopic content than Figures 10a and $10 \mathrm{c}$, Figure $10 \mathrm{~b}$ shows strong variation in isotopic content from 4 million meters to 3.3 million meters to the rise, as you approach the spreading ridge from 3.4 million meters to 1 million meters there is relative consistency in the readings appearing similarly to a bell curve with readings going from less radiogenic to more radiogenic and down to a 
less radiogenic signature once again readings, then from 1 million meters to 600,000 meters from the ridge where the samples from the Antarctic plate once again show a strong variation.

Figure 10c is a graph that compares ${ }^{208} \mathrm{~Pb} /{ }^{204} \mathrm{~Pb}$ ratio with distance to the spreading ridge, this graph shows a trend of isotopic content decreasing in radiogenic content as you approach the spreading ridge, there is one point of discontinuity with this overall trend and it lies around 500,000 meters from the spreading ridge. This comparison showed that in the ${ }^{208} \mathrm{~Pb} /{ }^{204} \mathrm{~Pb}$ and ${ }^{207} \mathrm{~Pb} /{ }^{204} \mathrm{~Pb}$ ratios there is a correlation of the radiogenic content of the sample with the distance of said sample to the ridge, displaying that the closer you move to the ridge the less radiogenic the samples seem to be. There was a small deviation from this in the Antarctic plate samples around 500,000 meters from the spreading ridge, but overall the trend is evident. The comparison of the data in this manner implies that the younger the sediment is, the less radiogenic it is likely to be.

\section{Variability of lead isotope ratios with depth}

Samples were also related to the depth within the core. Although there are similarities within the cores themselves the plots showed that there was not a strong correlation between the depth within the core and the overall isotopic content (Figure 11). The absence of parallel is most evident in the samples that range in core depth from 35 to 75 centimeters, there are very strong almost oscillating isotopic inconsistencies within this particular interval. In the part of Figure 11 that looks at ${ }^{207} \mathrm{~Pb} /{ }^{204} \mathrm{~Pb}$ vs. depth within the core the readings are relatively consistent from $15 \mathrm{~cm}$ to $35 \mathrm{~cm}$, from $35 \mathrm{~cm}$ to $75 \mathrm{~cm}$ there is a great deal of inconsistency in the isotopic content, from $75 \mathrm{~cm}$ to $110 \mathrm{~cm}$ the readings are once again consistent, a small inconsistency occurs at $115 \mathrm{~cm}$ and the final 
interval from $115 \mathrm{~cm}$ to $140 \mathrm{~cm}$ shows consistent values. The section of Figure 11 that looks at ${ }^{206} \mathrm{~Pb} /{ }^{204} \mathrm{~Pb}$ vs. depth within the core is very similar to the preceding ${ }^{207} \mathrm{~Pb} /{ }^{204} \mathrm{~Pb}$ portion. There is a difference in the $15 \mathrm{~cm}$ interval followed by readings are relatively consistent from $15 \mathrm{~cm}$ to $35 \mathrm{~cm}$, from $35 \mathrm{~cm}$ to $75 \mathrm{~cm}$ there is a great deal of inconsistency in the isotopic content, from $75 \mathrm{~cm}$ to $85 \mathrm{~cm}$ there is consistency, from $85 \mathrm{~cm}$ to $140 \mathrm{~cm}$ the readings are less consistent than in the other isotopic ratios with inconsistencies occurring

and in the final interval. In the part of Figure 11 that looks at ${ }^{208} \mathrm{~Pb} /{ }^{204} \mathrm{~Pb}$ vs. depth within the core the readings similar to the other two portions of the graph and are relatively consistent from $15 \mathrm{~cm}$ to $35 \mathrm{~cm}$, from $35 \mathrm{~cm}$ to $75 \mathrm{~cm}$ there is a great deal of inconsistency in the isotopic content, from $75 \mathrm{~cm}$ to $110 \mathrm{~cm}$ the readings are once again consistent, a large inconsistency occurs at $115 \mathrm{~cm}$ and the final interval from $115 \mathrm{~cm}$ to $140 \mathrm{~cm}$ shows consistent values.

\section{Comparison of Nazca Plate Sediments with Andean Lead Isotope Provinces}

When compared, the composition of the Nazca, Antarctic and Pacific Plate sediments analyzed in the present study relate to the ore lead isotope provinces in South America. The samples analyzed in this study show a strong correlation specifically with Province I lead isotopic signatures (Figure 8c) of Macfarlane et al, (1990). The Province I type lead signatures are indicative of coastal Chile and Perú, extending into the Western Cordillera and has been shown (Macfarlane et al, 1990) to originate from mixing of the magmatic source with crustal rock. There is a distinct lack of the more radiogenic isotopic readings similar to those in Province IIIb, which is comparable with the anomalous trend found in the northern Andes area of interest. Province IIIb gains its 
radiogenic signature from interaction with metamorphic basement rock (Macfarlane and Petersen, 1990).

\section{Comparison of Nazca Plate Sediments with Ecuador Ore Lead Isotope Ratios}

The compositions of my samples when compared with the Ecuador ores show a strong lack of agreement between their isotopic compositions. The new seafloor samples show a trend that is less radiogenic than those that are seen in the samples from northern Perú and Ecuador. The known data ranges for the Ecuador and northern Perú area of interest range from: ${ }^{206} \mathrm{~Pb} /{ }^{204} \mathrm{~Pb} 17.850$ to $19.979,{ }^{207} \mathrm{~Pb} /{ }^{204} \mathrm{~Pb} 15.547$ to 15.742 , and ${ }^{208} \mathrm{~Pb} /{ }^{204} \mathrm{~Pb} 38.019$ to 39.669 . It is worth mentioning that there are some samples in this set that are less radiogenic, but the overall trend is more radiogenic, as seen in Figure 2 and Figure 3. The data range for the seafloor samples in this study range from: ${ }^{206} \mathrm{~Pb} /{ }^{204} \mathrm{~Pb}$ 18.574 to $18.772,{ }^{207} \mathrm{~Pb} /{ }^{204} \mathrm{~Pb} 15.559$ to 15.644 , and ${ }^{208} \mathrm{~Pb} /{ }^{204} \mathrm{~Pb} 38.246$ to 38.759 . The new seafloor data shows top endmember results that are significantly less radiogenic than that of the continental area of interest. My results show that by comparison there is a very significant difference in the ratios of the new seafloor data with that of the more radiogenic continental data. The northern Perú, Ecuador, and new seafloor sediment data are plotted together on Figure $8 \mathrm{a}$ and $8 \mathrm{~b}$. The strong differences of $\mathrm{Pb}$ isotope ranges in the samples from Ecuador and northern Perú to those in the adjacent Pacific seafloor should be strongly emphasized. The lack of radiogenic content in the Nazca, Pacific and Antarctic plate data imply that the lead isotope composition of the northern Andes is coming from a source other than that of sediment subduction. 


\section{Implications for the Ecuadorian Ore Lead Isotope Trend}

One possible implication of the Ecuador ore lead isotope trend, now that the sediments can be written off is a difference in lead isotopic composition of the arc basement in Ecuador compared to Perú. Another possible source is the contamination of the magma within the crust by continental material, possibly including the sedimentary and metamorphic basement rock that causes a similar radiogenic signature in Macfarlane et al, (1990) Province IIIb. Most of the Ecuadorian sample sites are located within Cretaceous-Tertiary volcanics, Mesozoic volcanics and Mesozoic-Cenozoic intrusives (Figure 13) and a good deal of the sample sites are also located within the Macuchi formation (Figure 6). The rocks and ores that produce Province IIIb type isotopic signatures are known to have been the product of source magma interaction with Carboniferous-Permian sedimentary belts that are scattered throughout Perú (Figure 14) (Macfarlane, 2015). These sedimentary belts are not seen on a significant level in Ecuador at this time and further investigation would be needed in order to determine if they are indeed present, possibly underneath the volcanic rocks. The Macuchi Formation should also be looked at in great detail to determine if any of components are playing a role in the anomalous Ecuadorian lead isotope trend. There is also the possibility that the Ecuadorian subduction of the Carnegie Ridge has played a role in the isotopic structure of coastal Ecuador. However, these are all just hypotheses and need further research to test the legitimacy. 


\section{CONCLUSIONS}

The central Peruvian Andes have been well studied with respect to lead isotopic composition. Studies conducted by multiple groups, such as Macfarlane et al, (1990) and Gunnesch and Baumann (1990) have been successful in showing that there are distinct differences within the area based upon isotopic data. They have also shown that the isotopic signatures tend to show a higher radiogenic composition as you move further inland. Since lead isotopes can be attributed to their source rocks, they can be used to determine the processes that caused formation of a particular body of ore (Faure, 1986 and Bowen, 1988). This has been shown on the samples taken from the Central Peruvian Andes. However, the Ecuadorian Andes have not been as well studied and the isotopic data that exists for the area does not show a clear picture for the formation of the source rocks. This study has given insight into the source of ore genesis in the Ecuadorian Andes and helped to solve the isotopic differences found therein. A wide variety of studies that have successfully argued either for or against the possibility of the involvement of sediment subduction at convergent plate boundaries. Analysis of the lead isotopic composition of 36 new seafloor samples from the Nazca, South American and Antarctic plates have indicated it is unlikely that Pacific Ocean sediments can account for the radiogenic character of rocks and ores from northern Perú and Ecuador. This implies that there is another source for this feature, such as contamination of the magma within the crust by continental material, possibly including the metamorphic basement rock that causes a similar radiogenic signature in Macfarlane et al, (1990) Province IIIb, but further study would be needed to prove the validity of that notion. 
In general, the lead isotopic compositions of the Nazca Plate are quite homogenous and are a close match with Andean ore lead isotope Province I, typical or ores from the coastal arc from central Perú through south-central Chile. This supports the concept that the lead isotope ratios of these deposits are dominated by subducted sediments. However, no sign of the more radiogenic isotopic signature seen in Ecuadoran ores was found in these samples. Therefore, no evidence was found that changes in the isotopic composition of subducted sediment can explain the change in ore lead isotope ratios in ores in northern Perú and Ecuador. This northern trend probably originates from differences in the continental crust. 


\section{FUTURE RESEARCH}

Future research into the differences in of lead isotopic composition of Tertiary Ecuadorian ores is needed in order to reach a definitive conclusion about the ore forming processes of the area. This research should include an investigation of continental crust in Ecuador compared with that found in Perú (Figures 13 and 14). There should be an examination of the amount of crustal assimilation and interaction with subductiongenerated magma, both of which could alter the lead isotopic signatures of the original source magmas. Attention should be paid to the interaction of Ecuadorian arc source magmas with upper crustal rocks containing high ${ }^{206} \mathrm{~Pb} /{ }^{204} \mathrm{~Pb}$ values like those known to have caused the Province IIIb type deposits in the central Andes. Also consideration should be taken as to whether there was contamination of the source magma by country rock accompanied by fractional crystallization of compatible elements, resulting in a magma enriched in incompatible elements. 


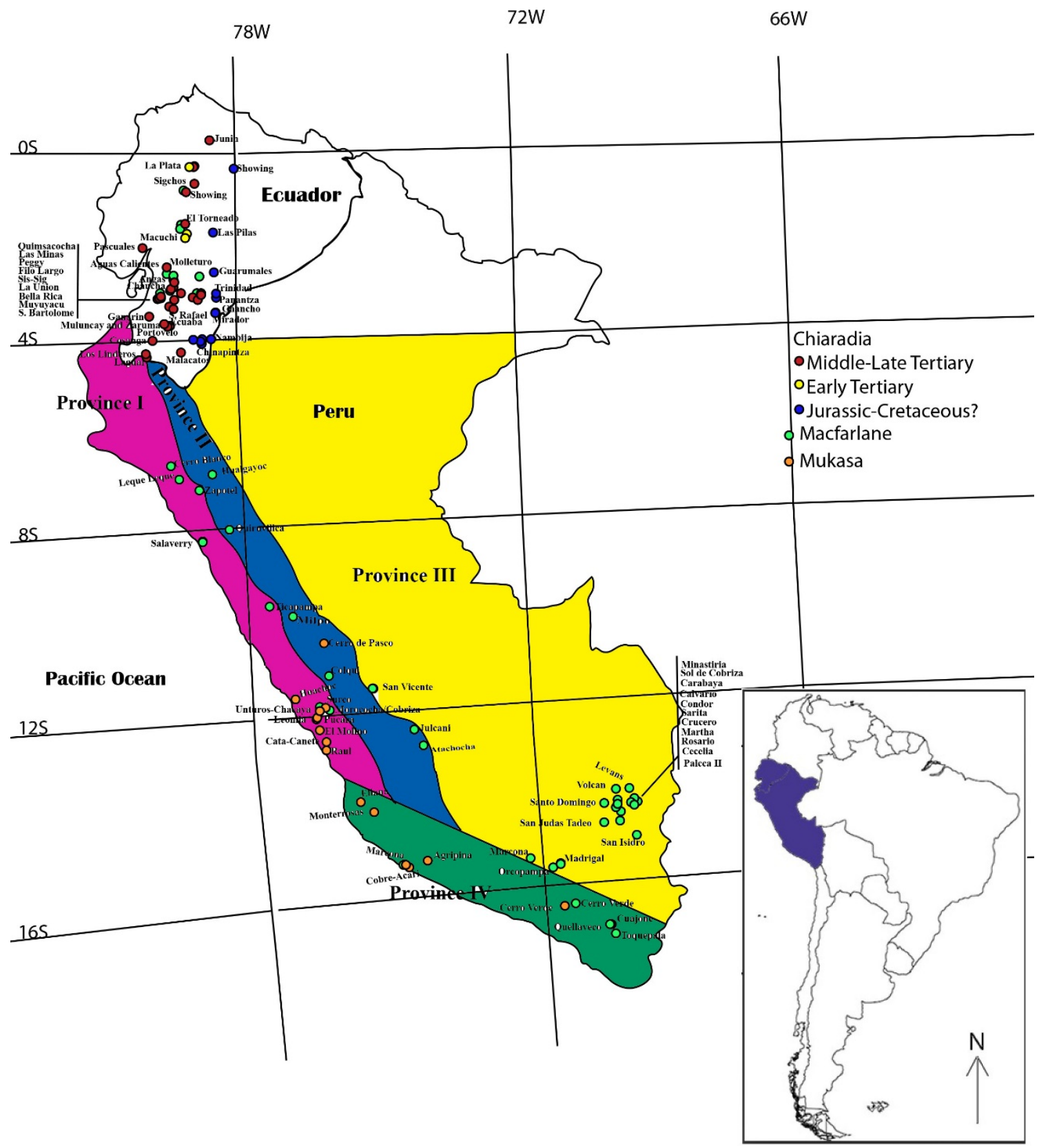

Figure 1. KNOWN DATA PLOTS FROM ECUADOR AND PERÚ ON MAP. Area of interest showing Ecuador and Perú in northwestern South America including previous sample localities of data collection from: Chiaradia and Fontboté, 2001, Chiaradia et al, 2004, Kamenov and Macfarlane 2002, Mukasa and Injoque-Espinoza 1990, Kontak et al 1990, Mafarlane and Lechtman 2014, Tosdal 1996 and White unpublished Thesis 1994. 


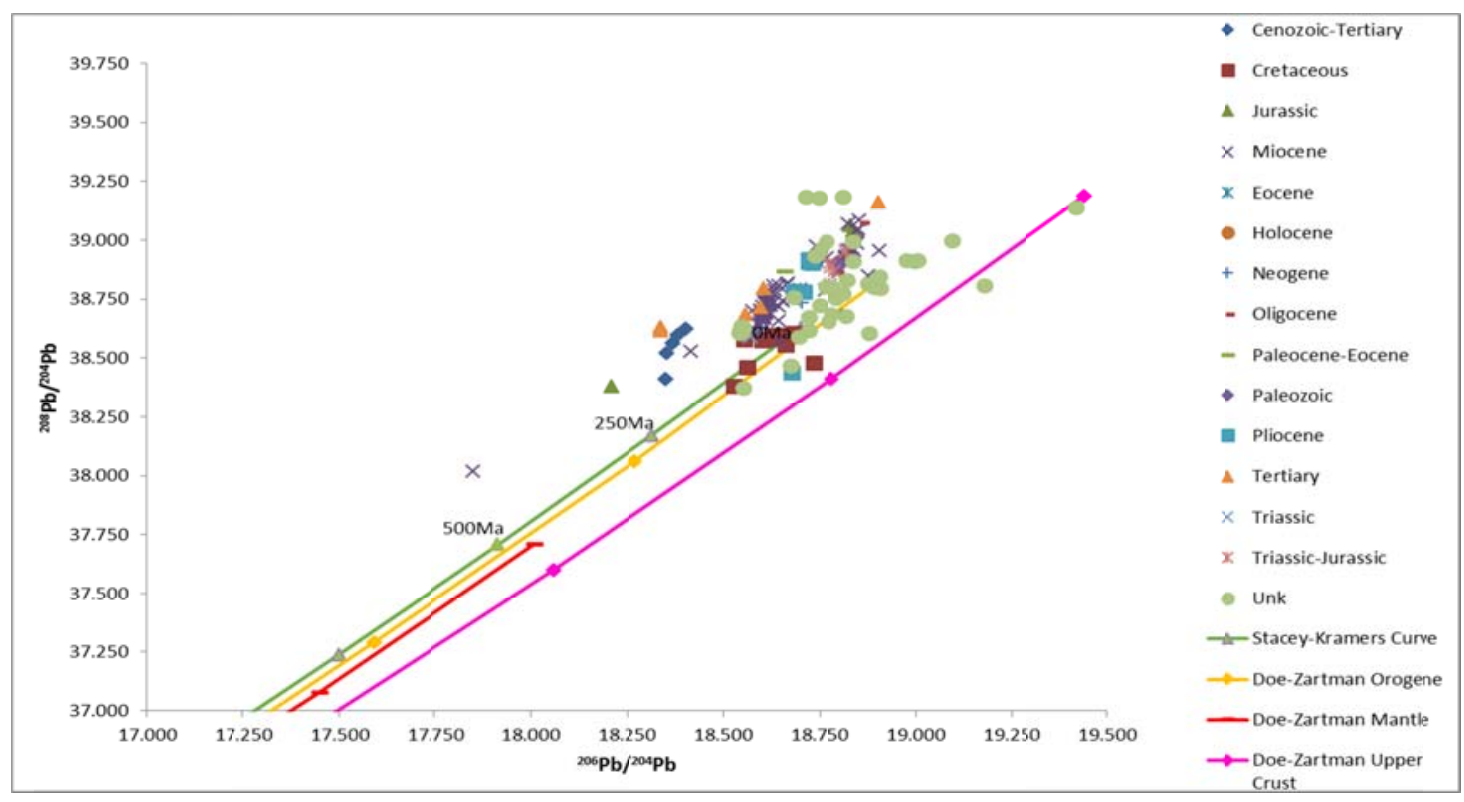

Figure 2a PREVIOUS PERUVIAN DATA: Lead isotope ${ }^{208} \mathrm{~Pb} /{ }^{204} \mathrm{~Pb}$ vs. ${ }^{206} \mathrm{~Pb} /{ }^{204} \mathrm{~Pb}$ data plots from ore found in Perú processed and published by Chiaradia and Fontboté 2001, Chiaradia et al. 2004, Mukasa and Injoque-Espinoza 1990, Kontak et al 1990 and Tosdal 1996. Doe and Zartman's curves which represent the isotopic content of the composition types: orogene, upper crust and mantle, through time along with Stacey-Kramers curves which represent the isotopic content of the estimated bulk composition of Earth through time are plotted here also for reference.

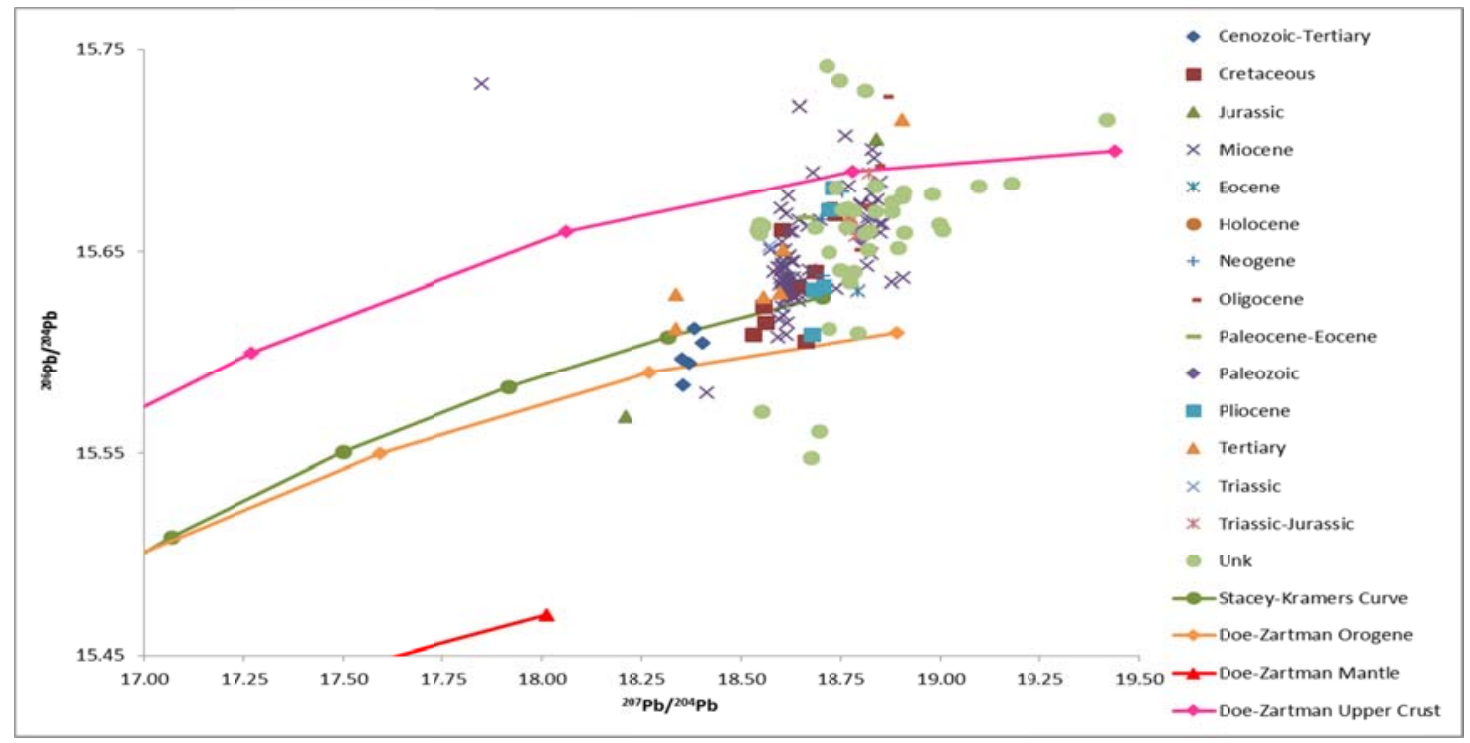

Figure 2b PREVIOUS PERUVIAN DATA: Lead isotope ${ }^{207} \mathrm{~Pb} /{ }^{204} \mathrm{~Pb}$ vs. ${ }^{206} \mathrm{~Pb} /{ }^{204} \mathrm{~Pb}$ data plots from ore found in Perú processed and published by Chiaradia and Fontboté 2001, Chiaradia et al. 2004, Mukasa and Injoque-Espinoza 1990, Kontak et al 1990 and Tosdal 1996. Doe and Zartman and Stacey-Kramers curves are plotted for reference (explanation in Figure 2a). 


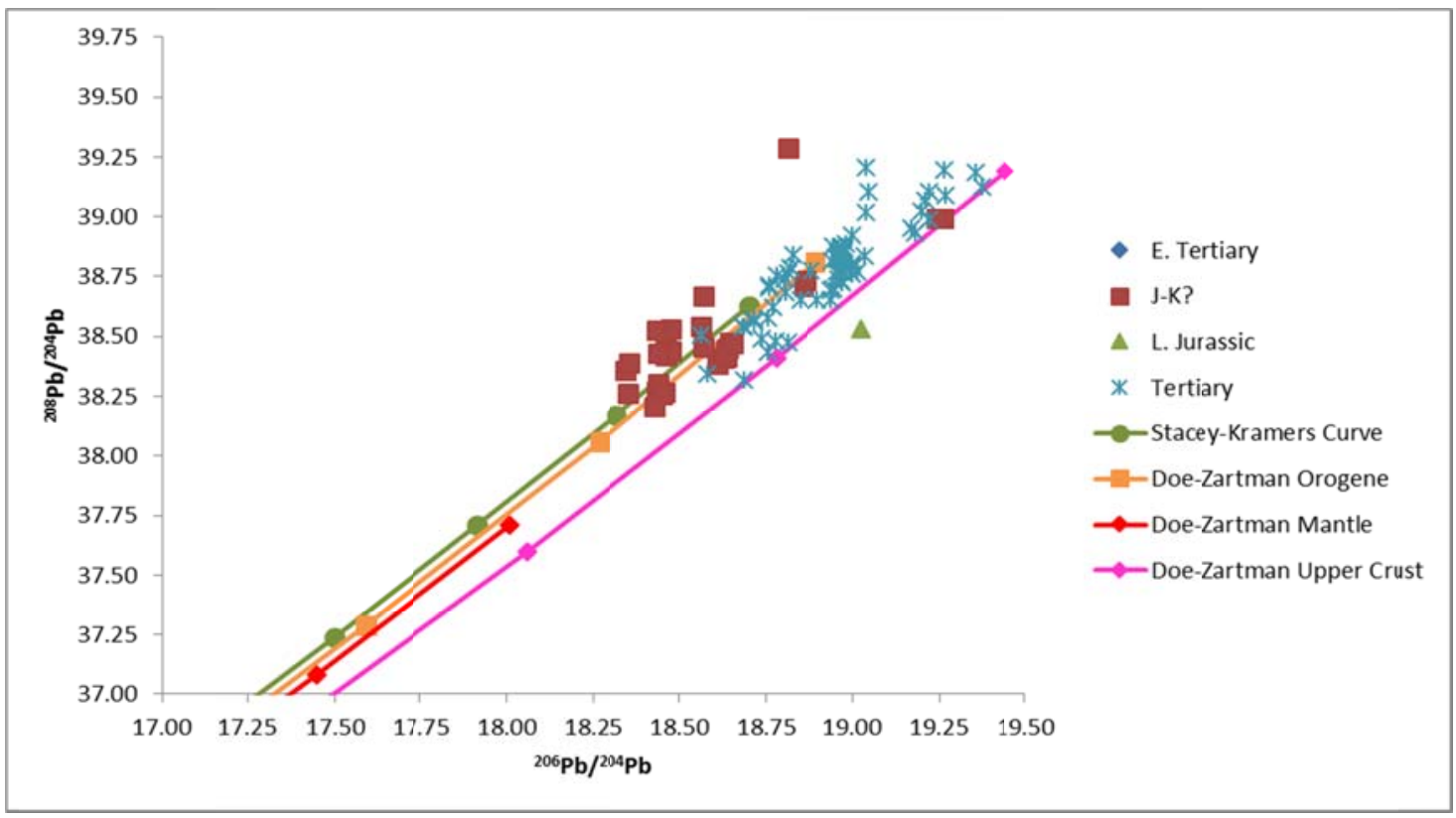

Figure 3. PREVIOUS ECUADORIAN DATA: Lead isotope ${ }^{208} \mathrm{~Pb} /{ }^{204} \mathrm{~Pb}$ vs. ${ }^{206} \mathrm{~Pb} /{ }^{204} \mathrm{~Pb}$ data plots from ore found in Ecuador processed and published by Chiaradia and Fontboté 2001, Chiaradia et al., 2004, White unpublished Thesis 1994. Doe and Zartman and Stacey-Kramers curves are plotted for reference (explanation in Figure 2a).

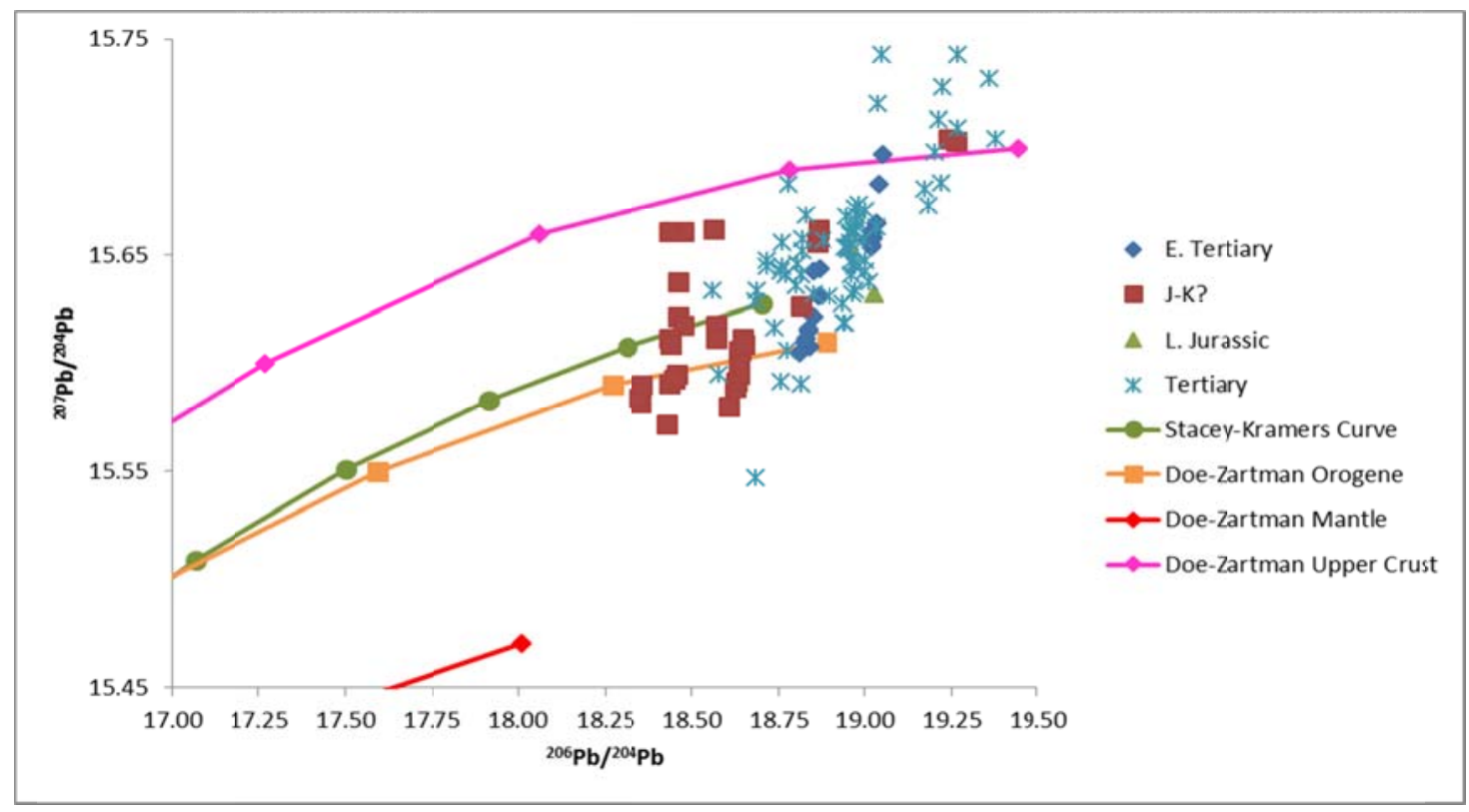

Figure 3. PREVIOUS ECUADORIAN DATA: Lead isotope ${ }^{207} \mathrm{~Pb} /{ }^{204} \mathrm{~Pb}$ vs. ${ }^{206} \mathrm{~Pb} /{ }^{204} \mathrm{~Pb}$ data plots from ore found in Ecuador processed and published by Chiaradia and Fontboté 2001, Chiaradia et al., 2004, White unpublished Thesis 1994. Doe and Zartman and Stacey-Kramers curves are plotted for reference (explanation in Figure 2a). 


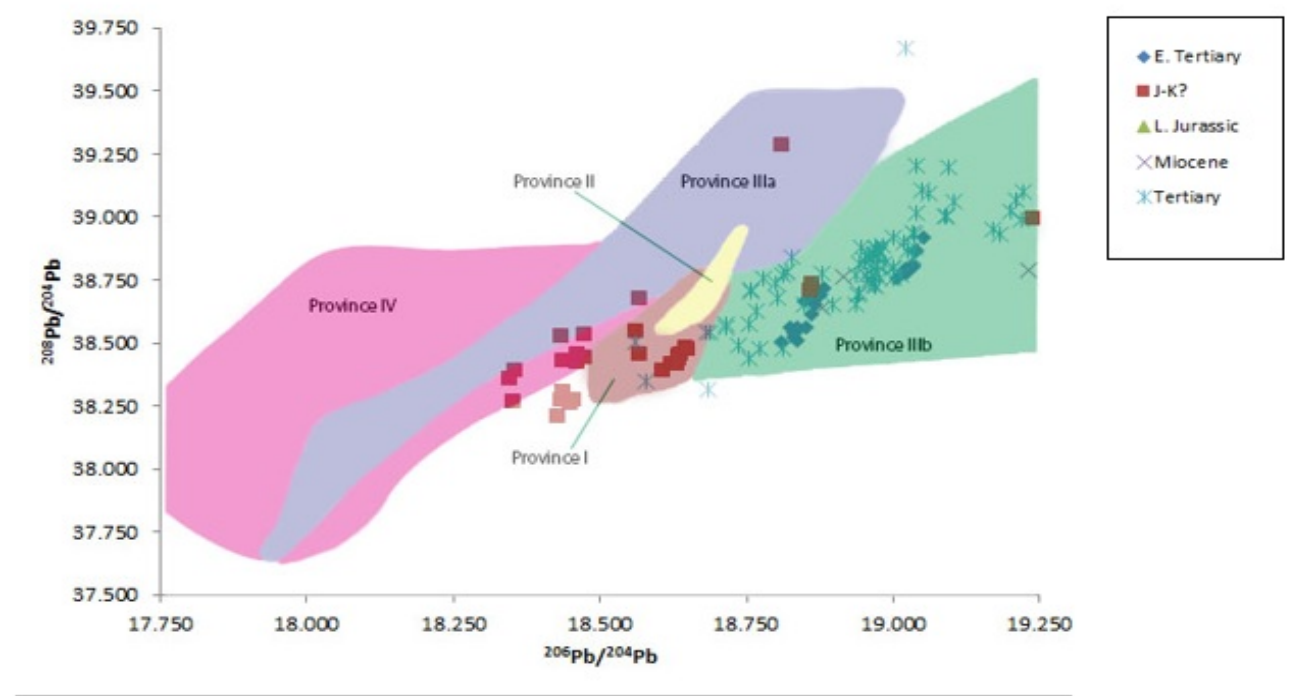

Figure 4 PREVIOUS ECUADORIAN DATA PLOTTED AGAINST MACFARLANE'S 2014 LEAD ORE PROVINCES: Lead isotope data plots from ore found in Ecuador processed and published by Chiaradia and Fontboté 2001, Chiaradia et al., 2004, Macfarlane and Lechtman, 2014, White unpublished Thesis 1994. 


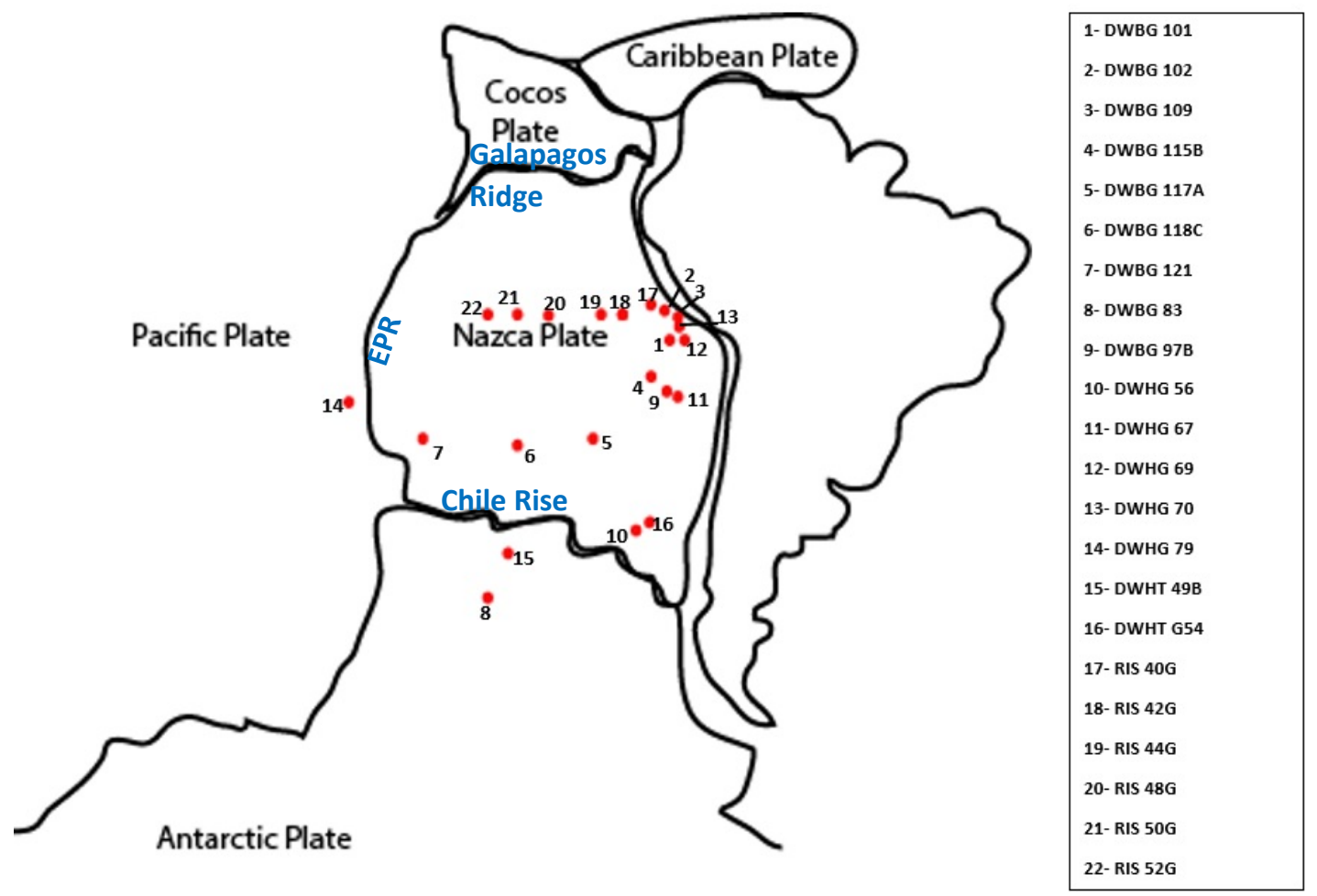

Figure 5 SAMPLE SITES FROM RISEPAC AND DOWNWIND EXPEDITIONS ANALYZED IN THIS STUDY 


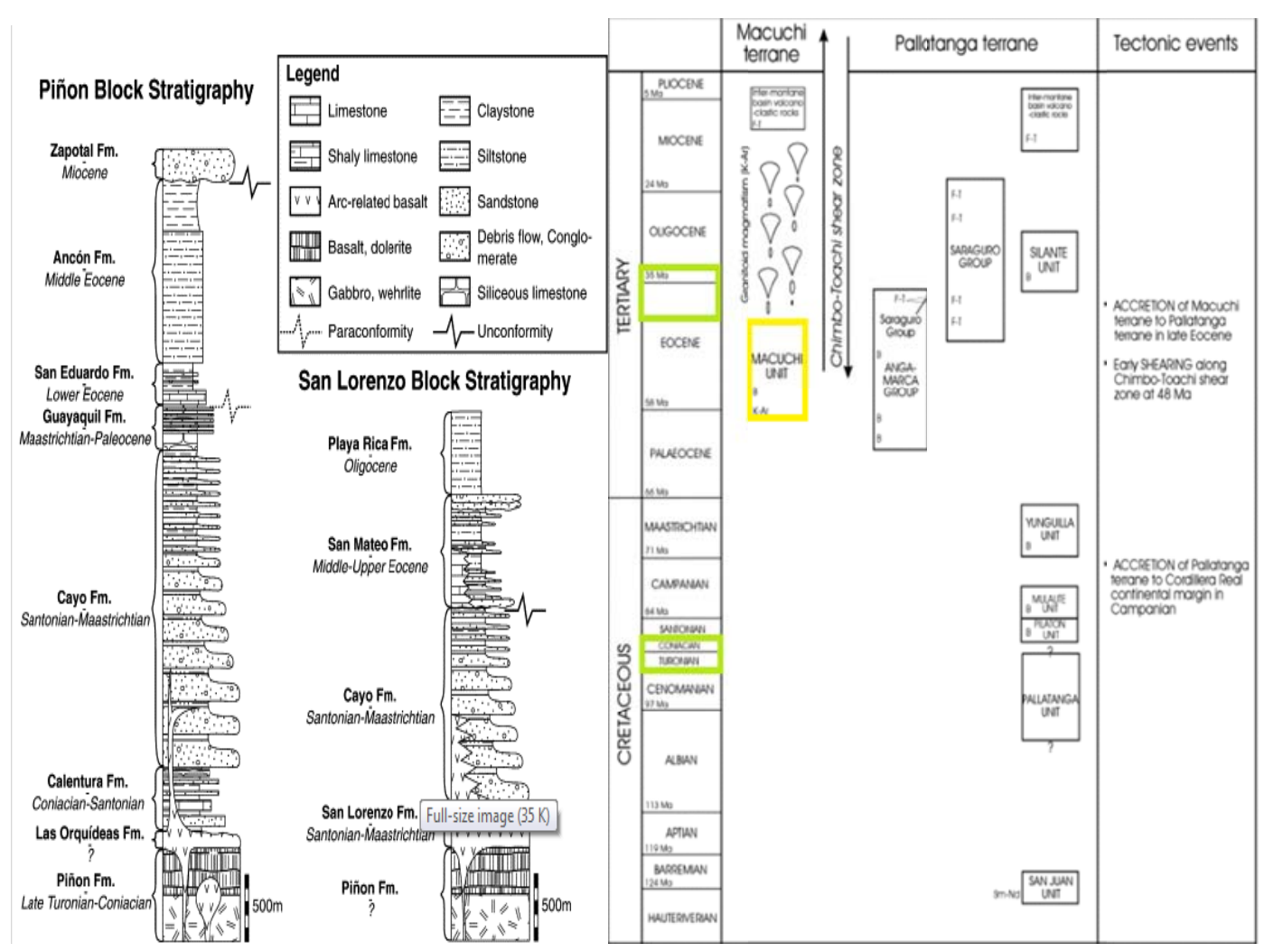

Figure 6 STRATIGRAPHIC SECTION OF THE AREA OF INTEREST published by Luzieux, L. D. A., Heller, F., Spikings, R., Vallejo, C. F., \& Winkler, W. (2006) 


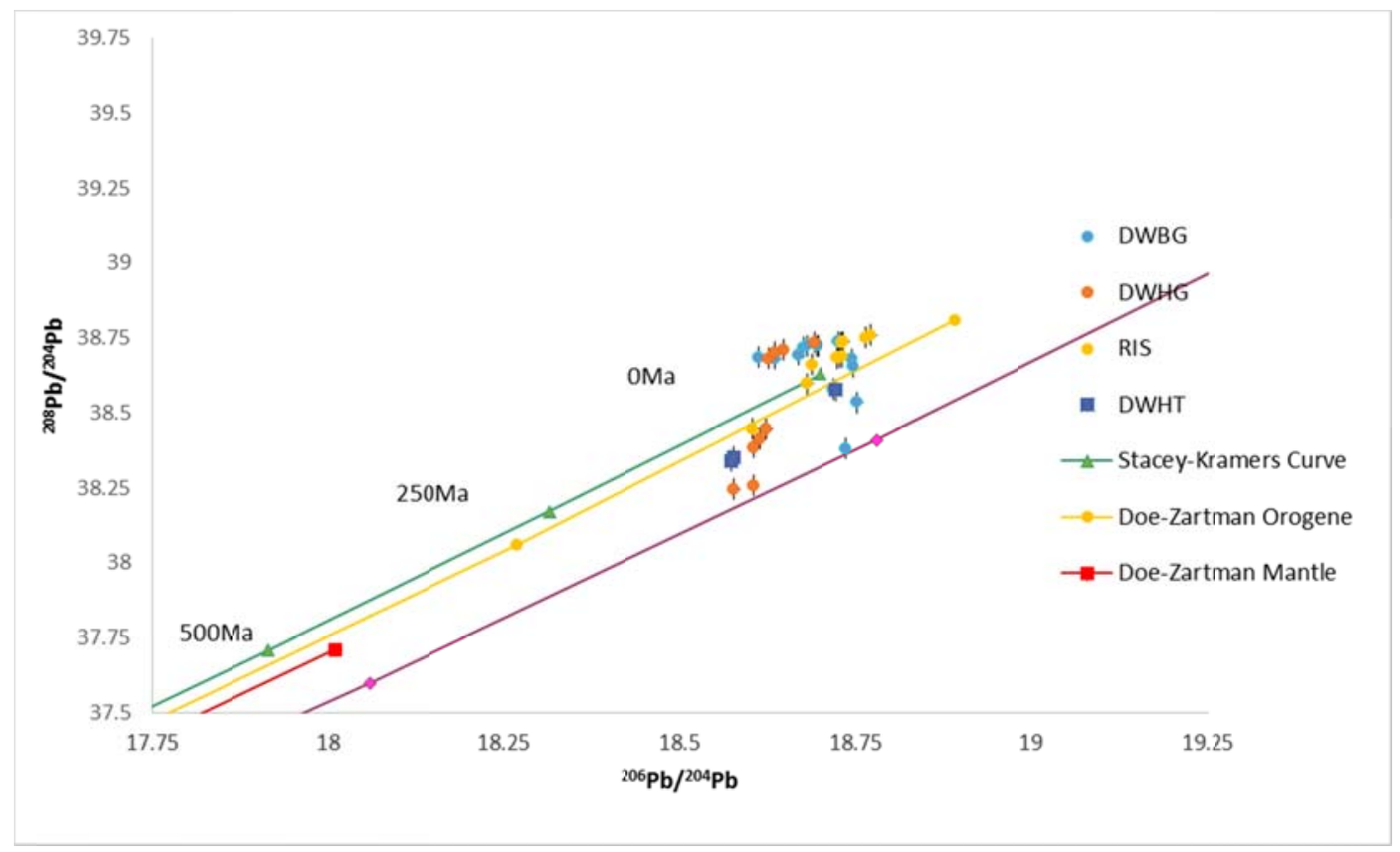

Figure 7a GRAPH OF SEAFLOOR ISOTOPIC DATA ${ }^{208} \mathrm{~Pb} /{ }^{204} \mathrm{~Pb}$ vs. ${ }^{206} \mathrm{~Pb} /{ }^{204} \mathrm{~Pb}$ Doe and Zartman and Stacey-Kramers curves are plotted for reference (explanation in Figure 2a).

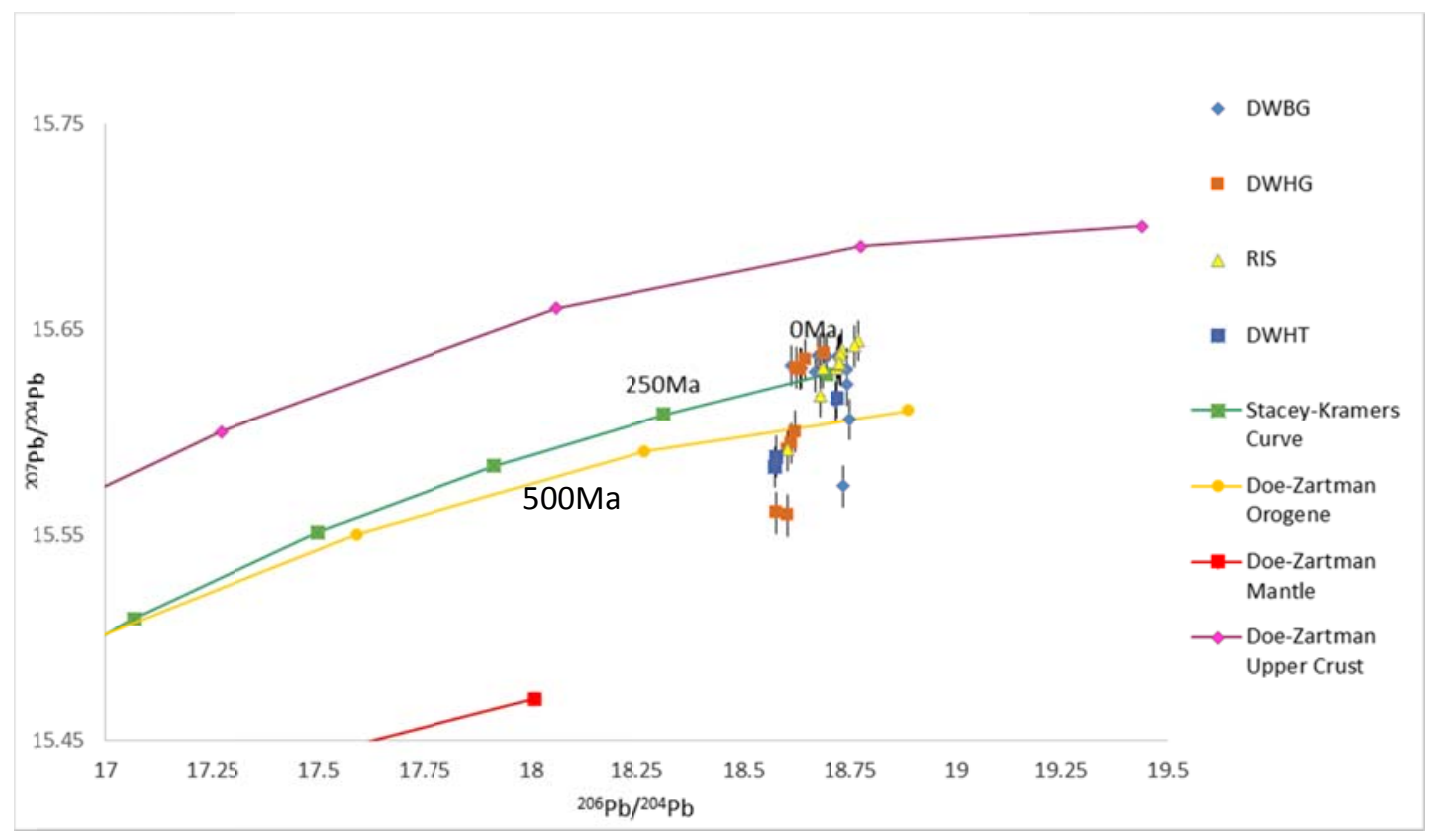

Figure 7b GRAPH OF SEAFLOOR ISOTOPIC DATA ${ }^{207} \mathrm{~Pb} /{ }^{204} \mathrm{~Pb}$ vs. ${ }^{206} \mathrm{~Pb} /{ }^{204} \mathrm{~Pb}$, Doe and Zartman and Stacey-Kramers curves are plotted for reference (explanation in Figure 2a). 


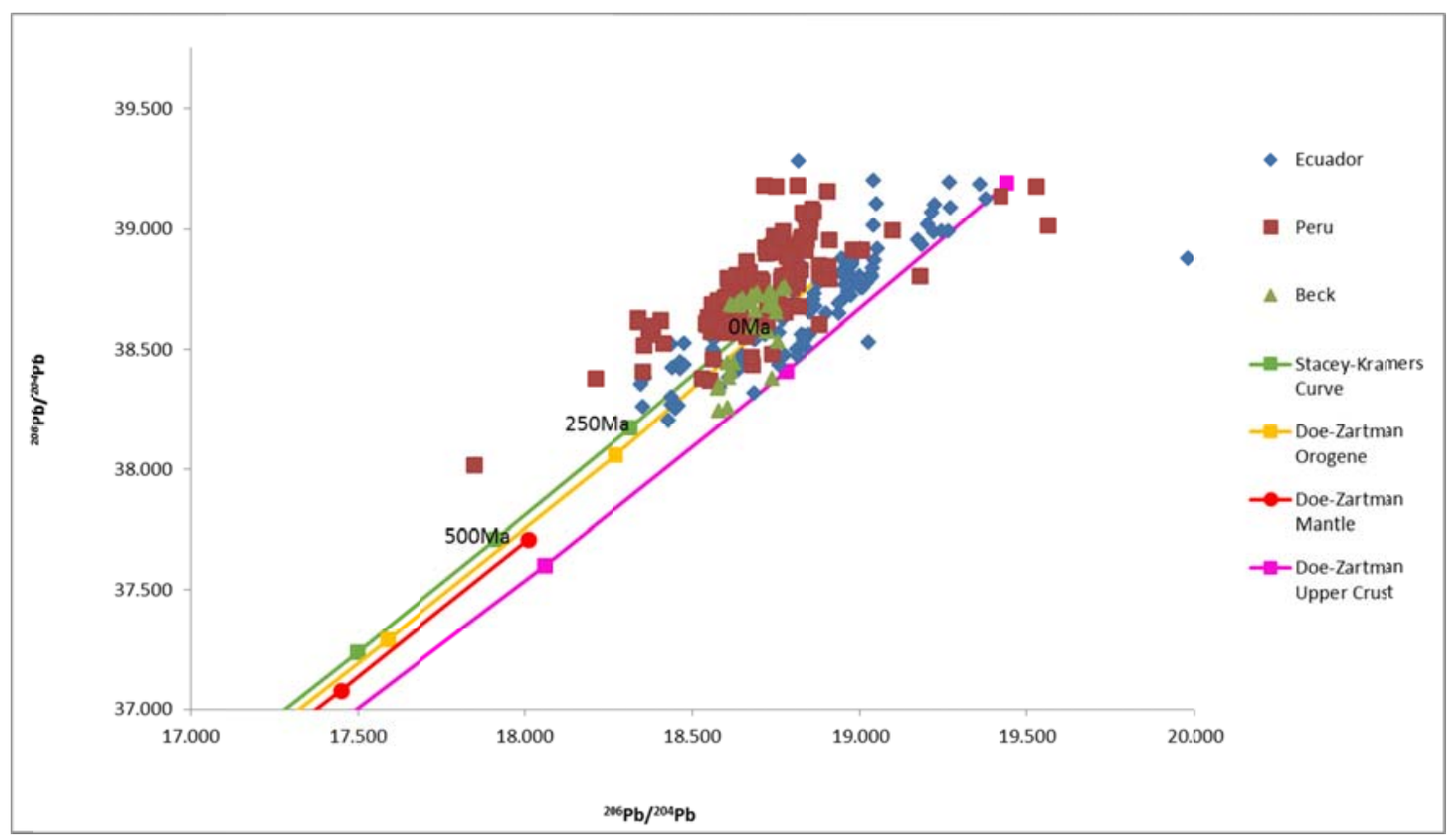

Figure 8a SEAFLOOR DATA COMPARED TO AREA OF INTEREST ${ }^{208} \mathrm{~Pb} /{ }^{204} \mathrm{~Pb}$ vs.

${ }^{206} \mathrm{~Pb} /{ }^{204} \mathrm{~Pb}$, Doe and Zartman and Stacey-Kramers curves are plotted for reference (explanation in Figure 2a).

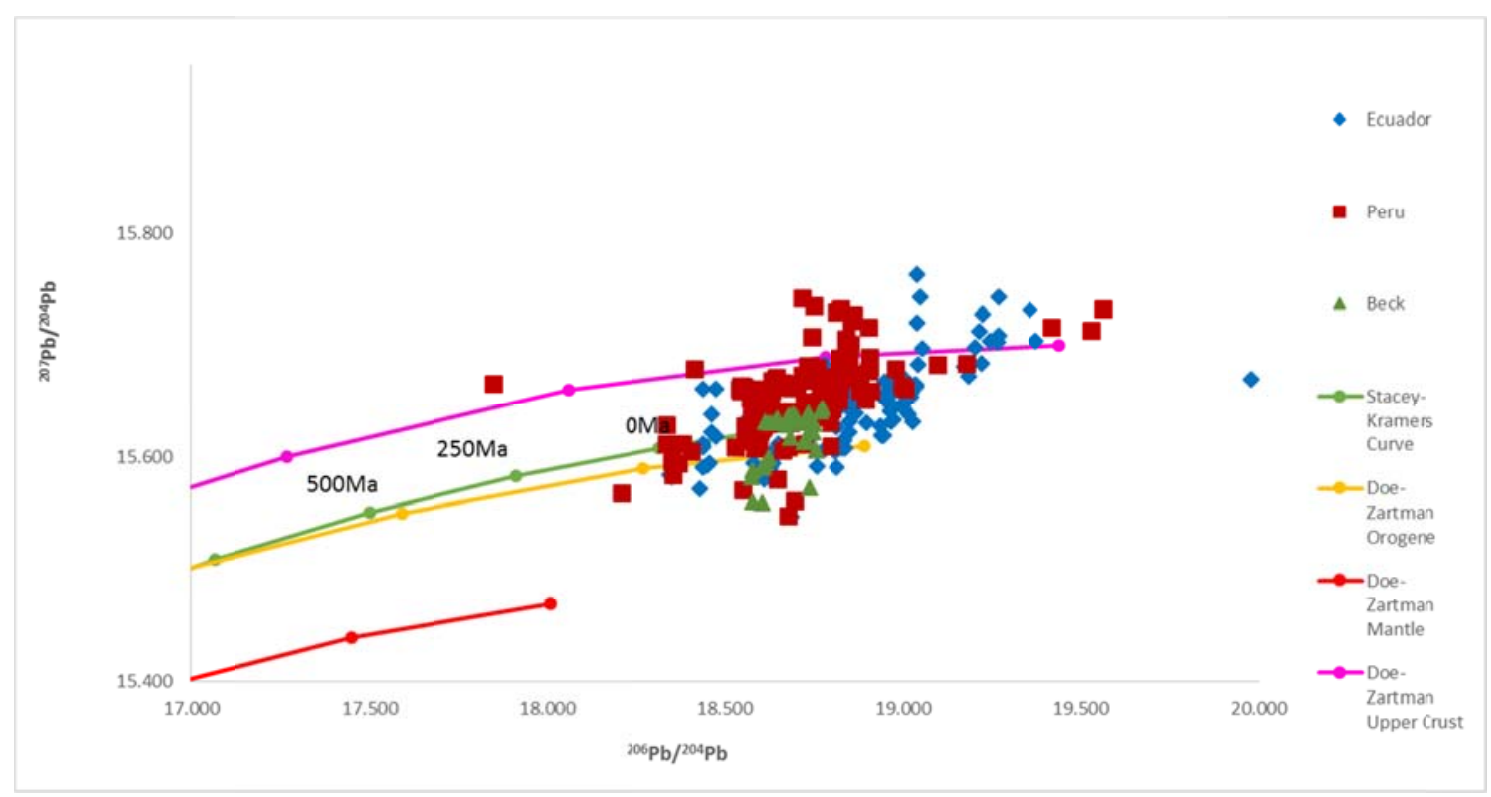

Figure 8b SEAFLOOR DATA COMPARED TO AREA OF INTEREST ${ }^{207} \mathrm{~Pb} /{ }^{204} \mathrm{~Pb}$ vs.

${ }^{206} \mathrm{~Pb} /{ }^{204} \mathrm{~Pb}$, Doe and Zartman and Stacey-Kramers curves are plotted for reference (explanation in Figure 2a). 


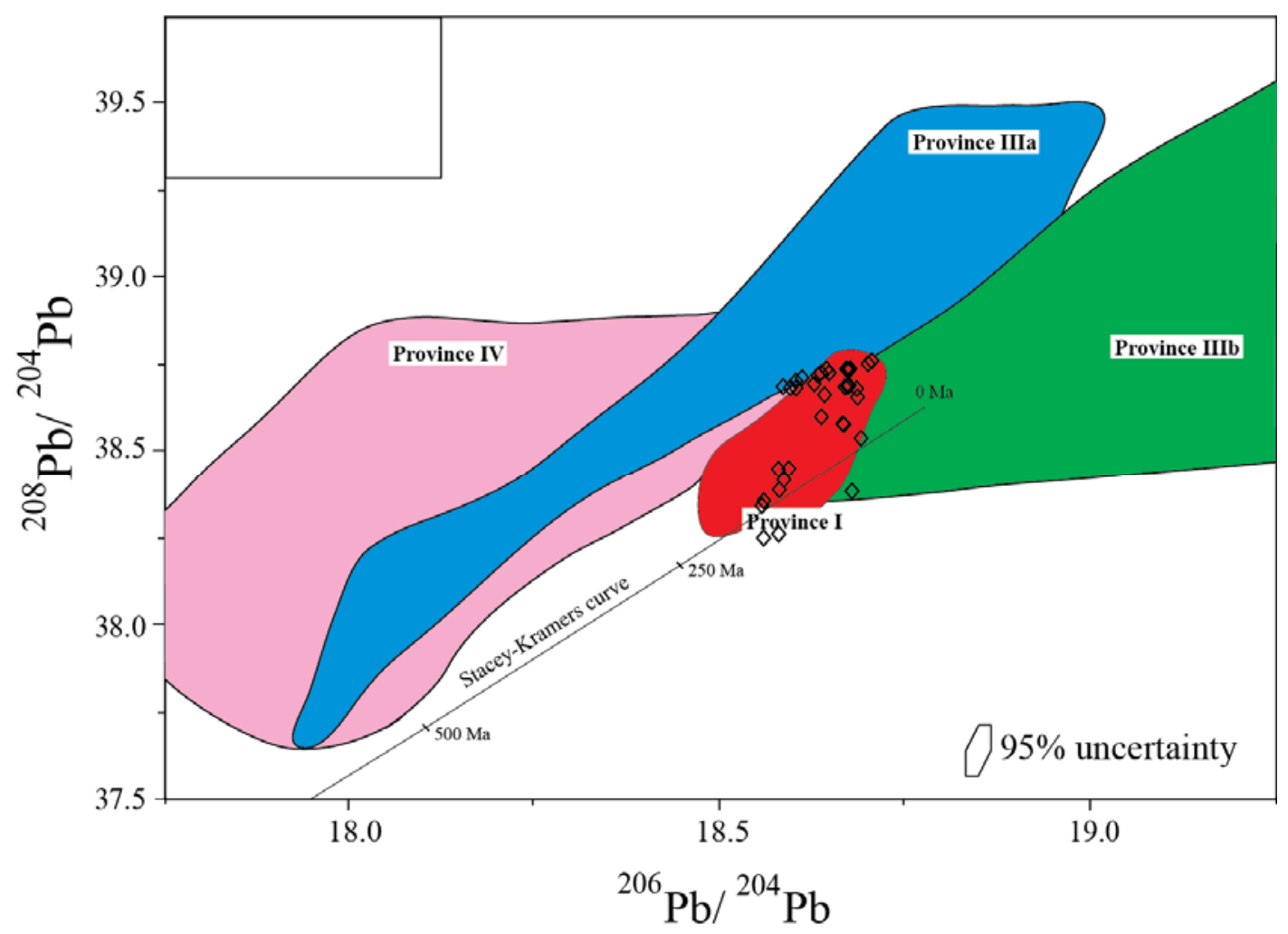

Figure 8c Seafloor data compared to Macfarlane's 2014 Lead Provinces, ${ }^{208} \mathrm{~Pb} /{ }^{204} \mathrm{~Pb}$ vs. ${ }^{206} \mathrm{~Pb} /{ }^{204} \mathrm{~Pb}$ 


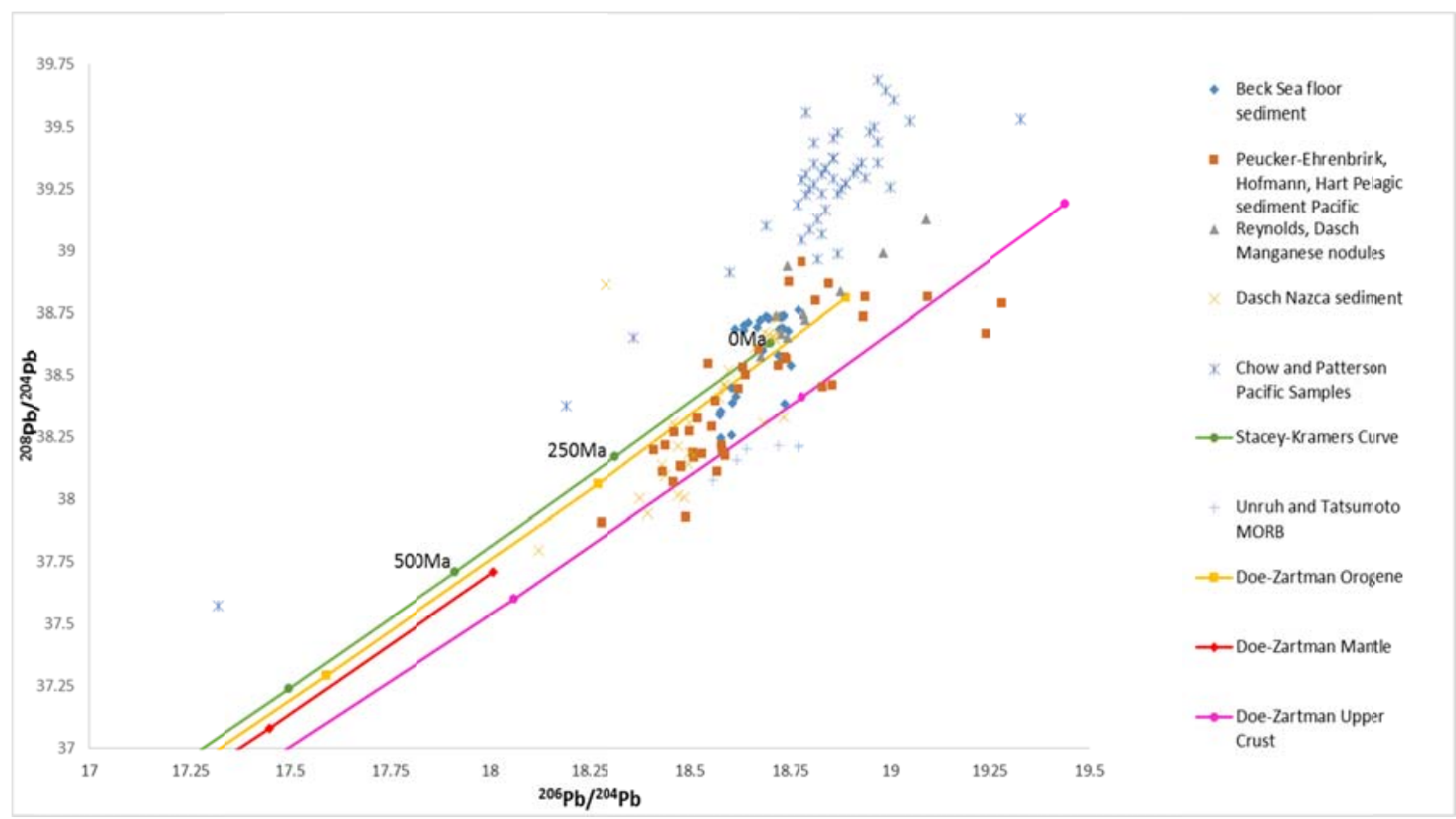

Figure 9a NEW SEAFLOOR DATA COMPARED TO KNOWN PACIFIC SEAFLOOR DATA, ${ }^{208} \mathrm{~Pb} /{ }^{204} \mathrm{~Pb}$ vs. ${ }^{206} \mathrm{~Pb} /{ }^{204} \mathrm{~Pb}$ Nazca sediment data and manganese nodule data, Doe and Zartman and Stacey-Kramers curves are plotted for reference (explanation in Figure 2a). (Dasch, Peucker-Ehrenbrink et al., Chow and Patterson, Unruh and Tatsumoto and Reynolds and Dasch)

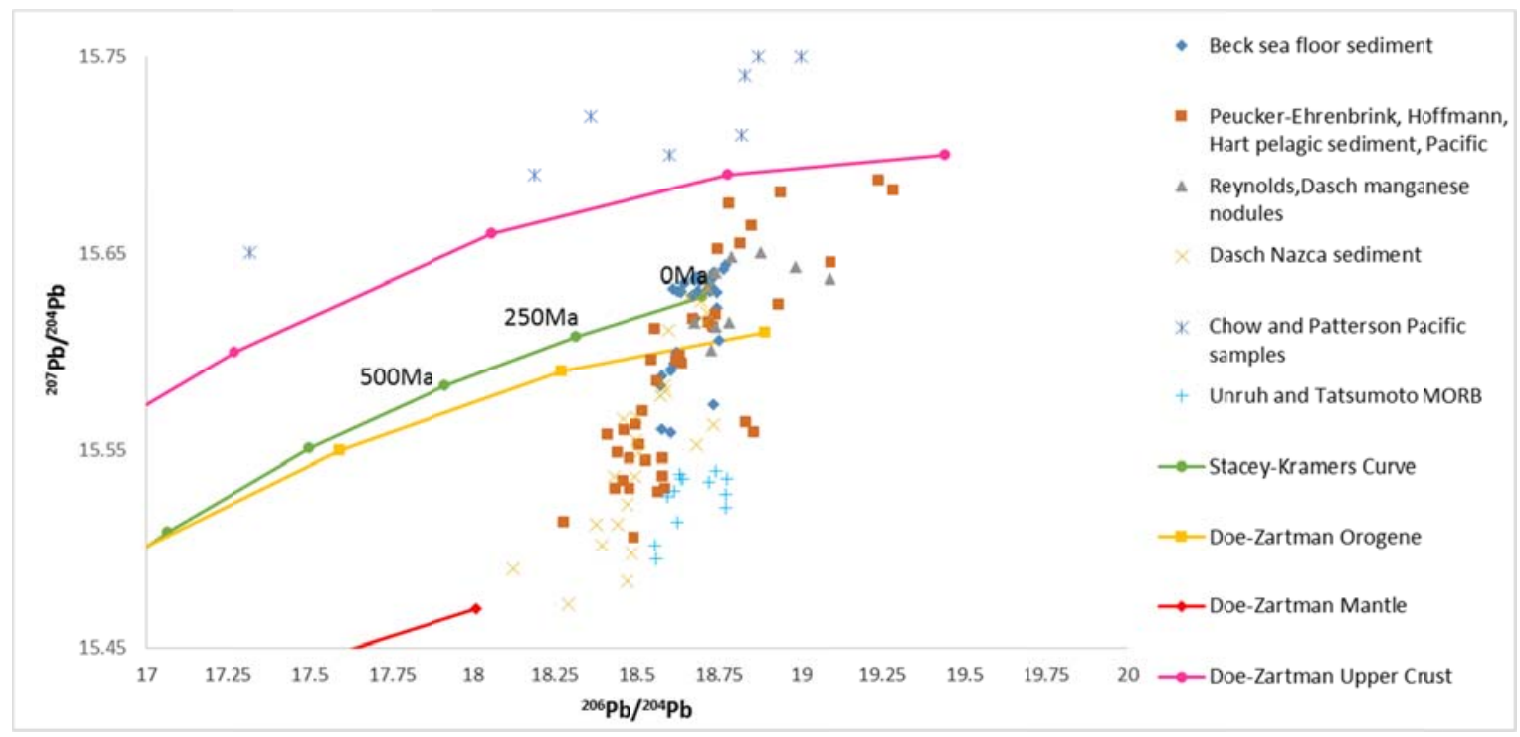

Figure 9b NEW SEAFLOOR DATA COMPARED TO KNOWN PACIFIC SEAFLOOR DATA, ${ }^{207} \mathrm{~Pb} /{ }^{204} \mathrm{~Pb}$ vs. ${ }^{206} \mathrm{~Pb} /{ }^{204} \mathrm{~Pb}$ Nazca sediment data and manganese nodule data, Doe and Zartman and Stacey-Kramers curves are plotted for reference (explanation in Figure 2a). (Dasch, Peucker-Ehrenbrink et al., Chow and Patterson, Unruh and Tatsumoto and Reynolds and Dasch) 


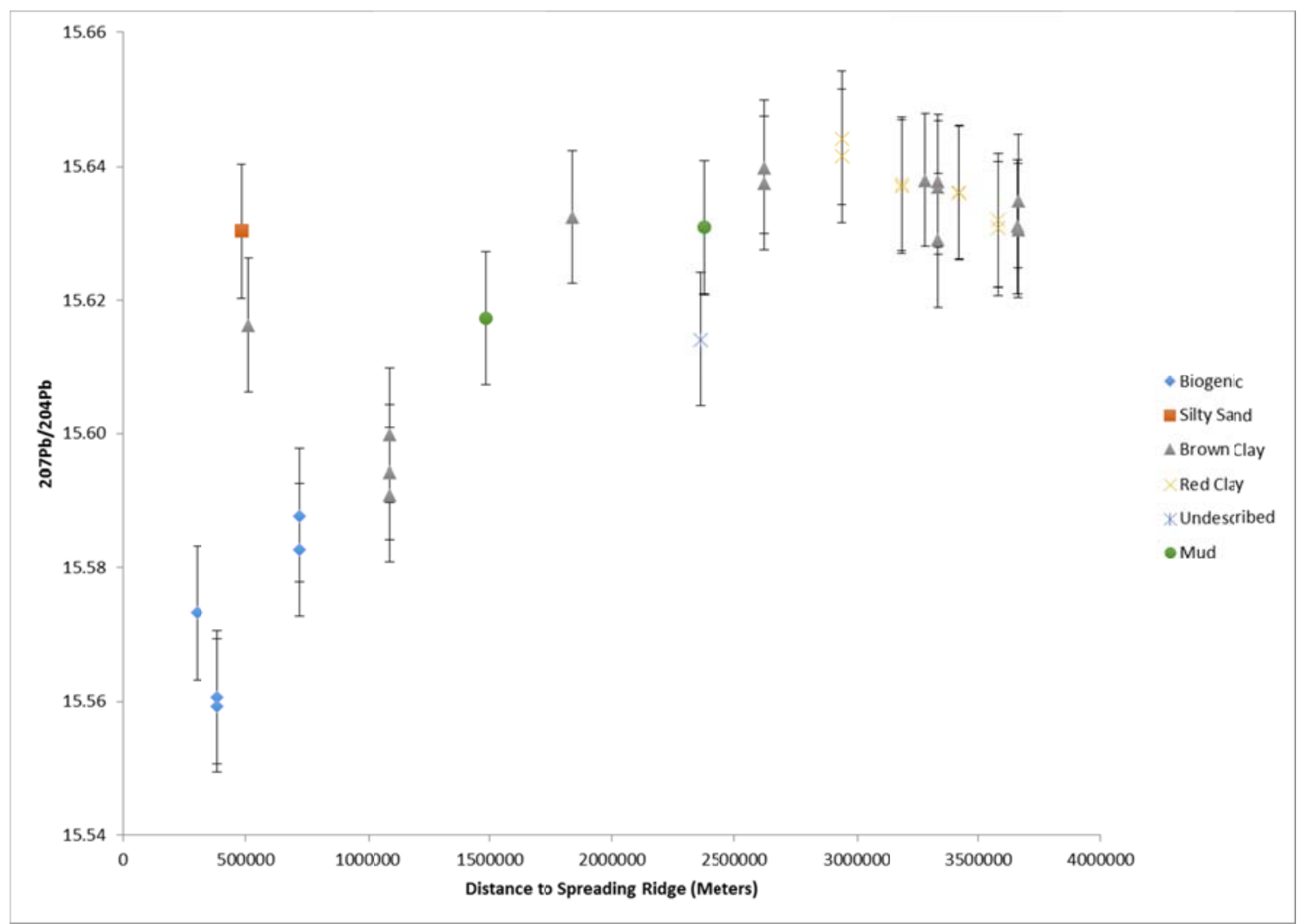

Figure 10a SEAFLOOR ISOTOPIC DATA PLOTTED BY DISTANCE FROM THE RIDGE, ${ }^{207} \mathrm{~Pb} /{ }^{204} \mathrm{~Pb}$, measured in meters in the direction of spreading. The plot is separated into sediment type, which is represented by the different markers. 


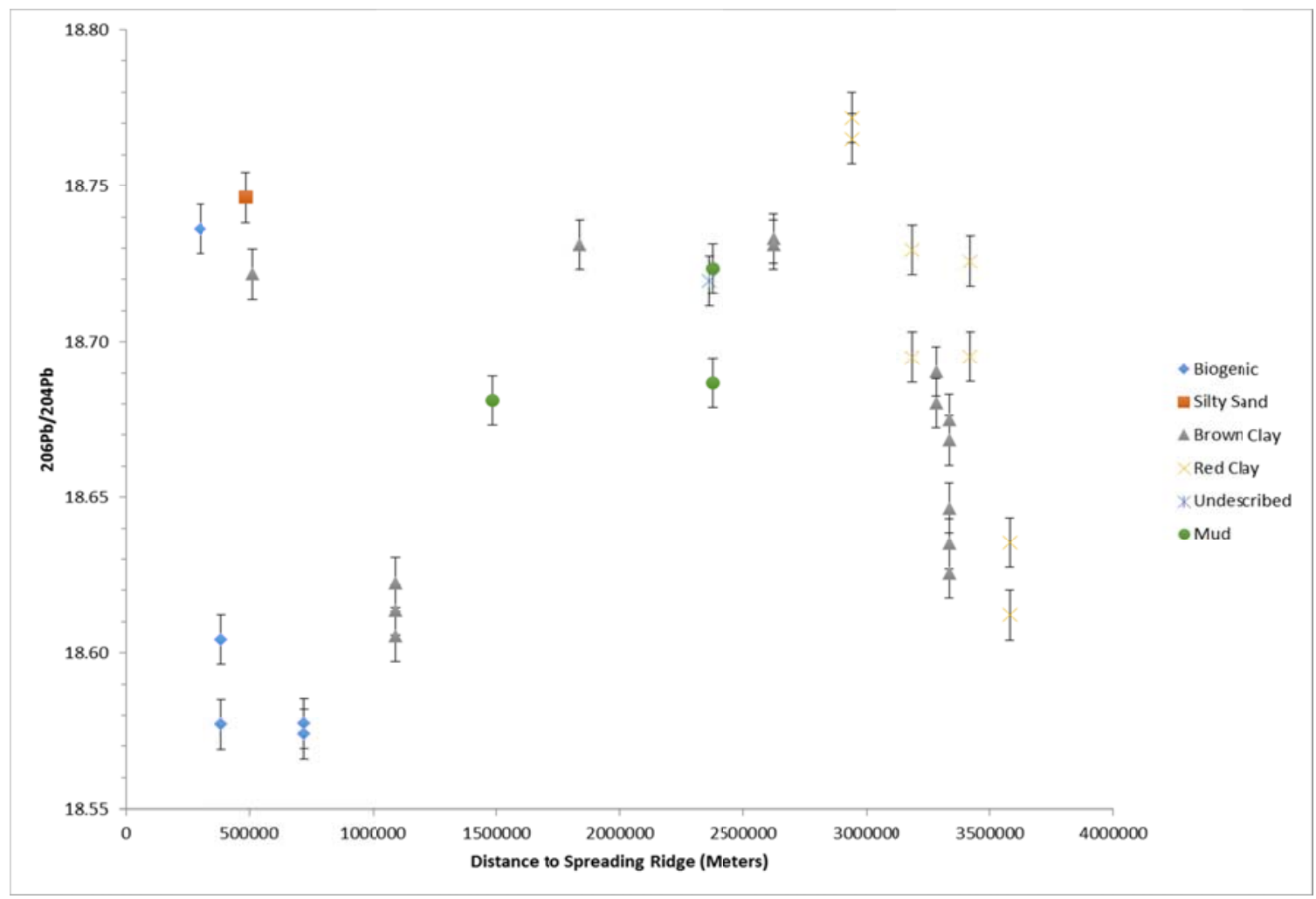

Figure 10b SEAFLOOR ISOTOPIC DATA PLOTTED BY DISTANCE FROM THE RIDGE, ${ }^{206} \mathrm{~Pb} /{ }^{204} \mathrm{~Pb}$, measured in meters in the direction of spreading. The plot is separated into sediment type, which is represented by the different markers. 


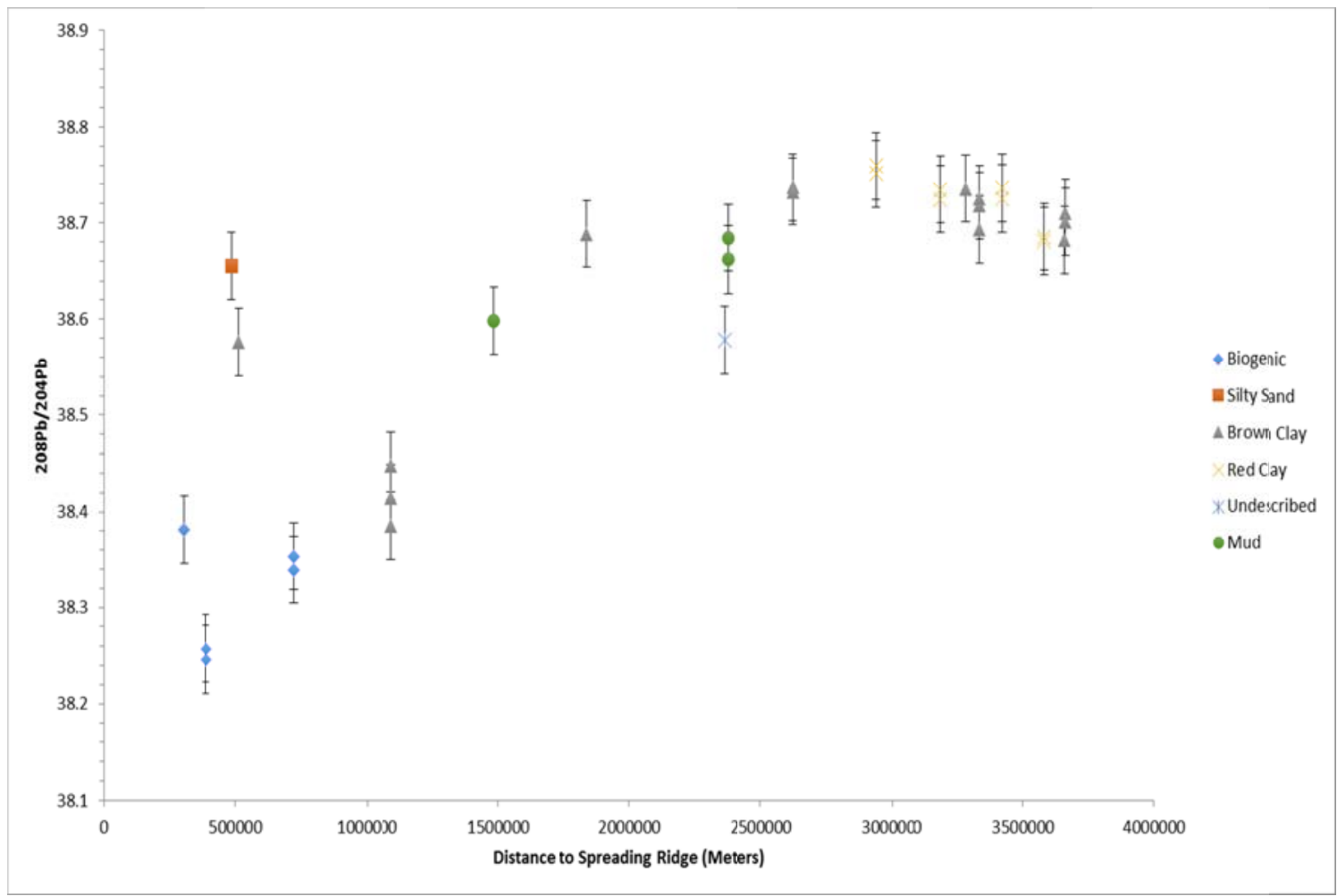

Figure 10c SEAFLOOR ISOTOPIC DATA PLOTTED BY DISTANCE FROM THE RIDGE, ${ }^{208} \mathrm{~Pb} /{ }^{204} \mathrm{~Pb}$, measured in meters in the direction of spreading. The plot is separated into sediment type, which is represented by the different markers. 


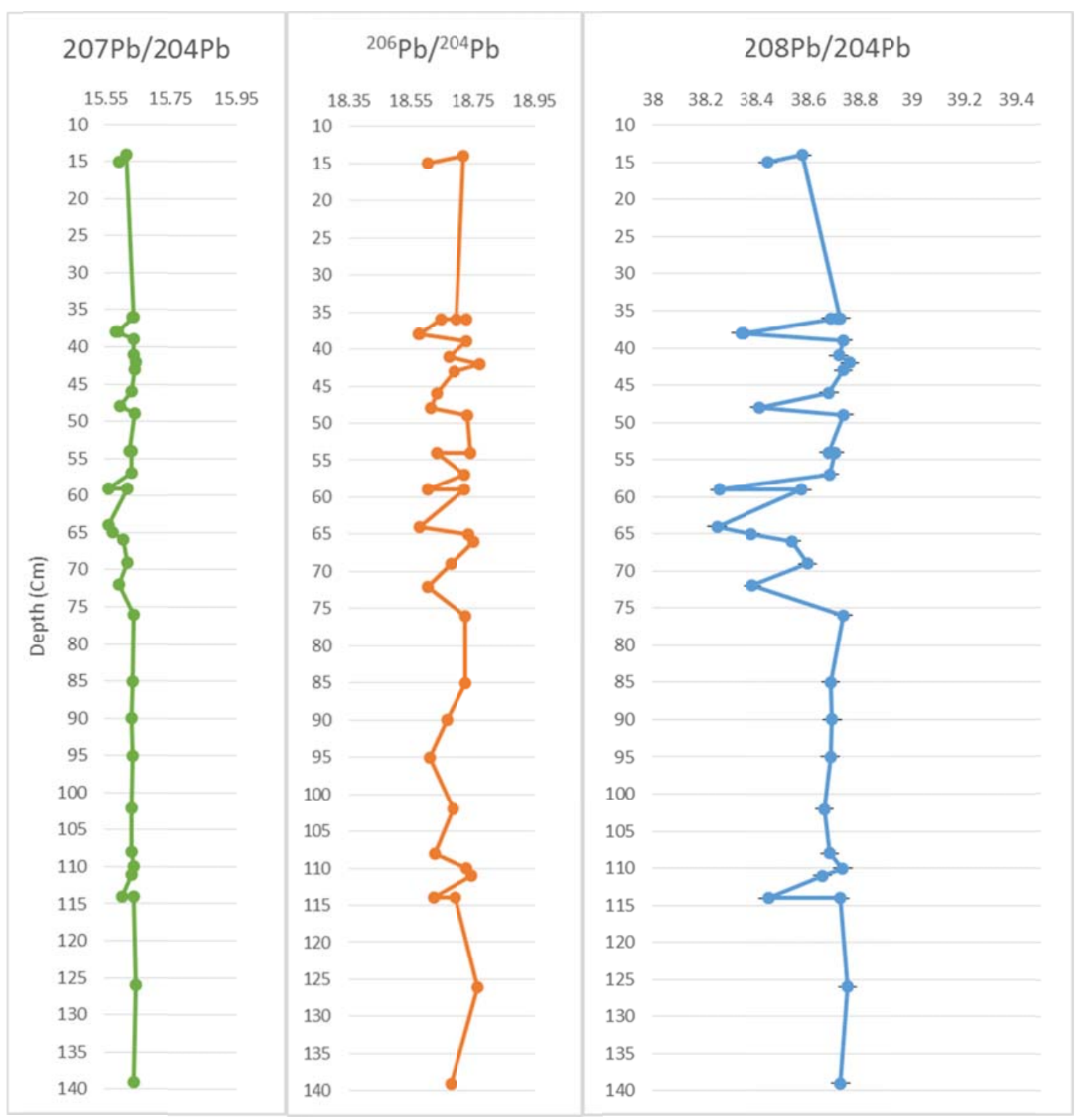

Figure 11 COMPARISON OF SEAFLOOR ISOTOPIC DATA BY DEPTH IN CORE $(\mathrm{cm})$, these graphs represent a compilation of all sample data, where error bars are not visible the estimated overall reproducibility of the analyses is smaller than the plot symbol. 


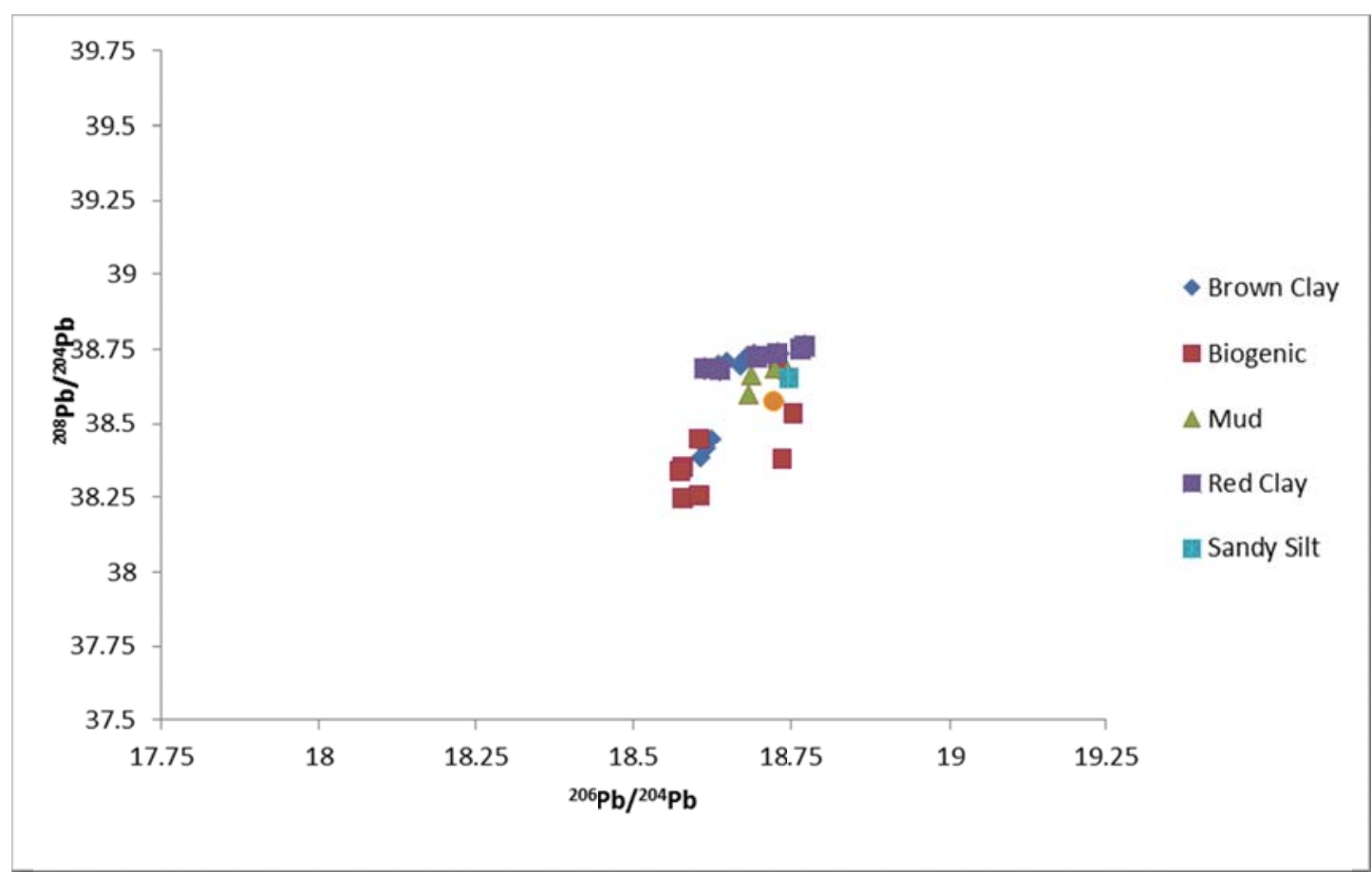

Figure 12a COMPARISON OF SEAFLOOR DATA BY SEDIMENT TYPE ${ }^{208} \mathrm{~Pb} /{ }^{204} \mathrm{~Pb}$ vs. ${ }^{206} \mathrm{~Pb} /{ }^{204} \mathrm{~Pb}$. Where error bars are not visible the estimated overall reproducibility of the analyses is smaller than the plot symbol.

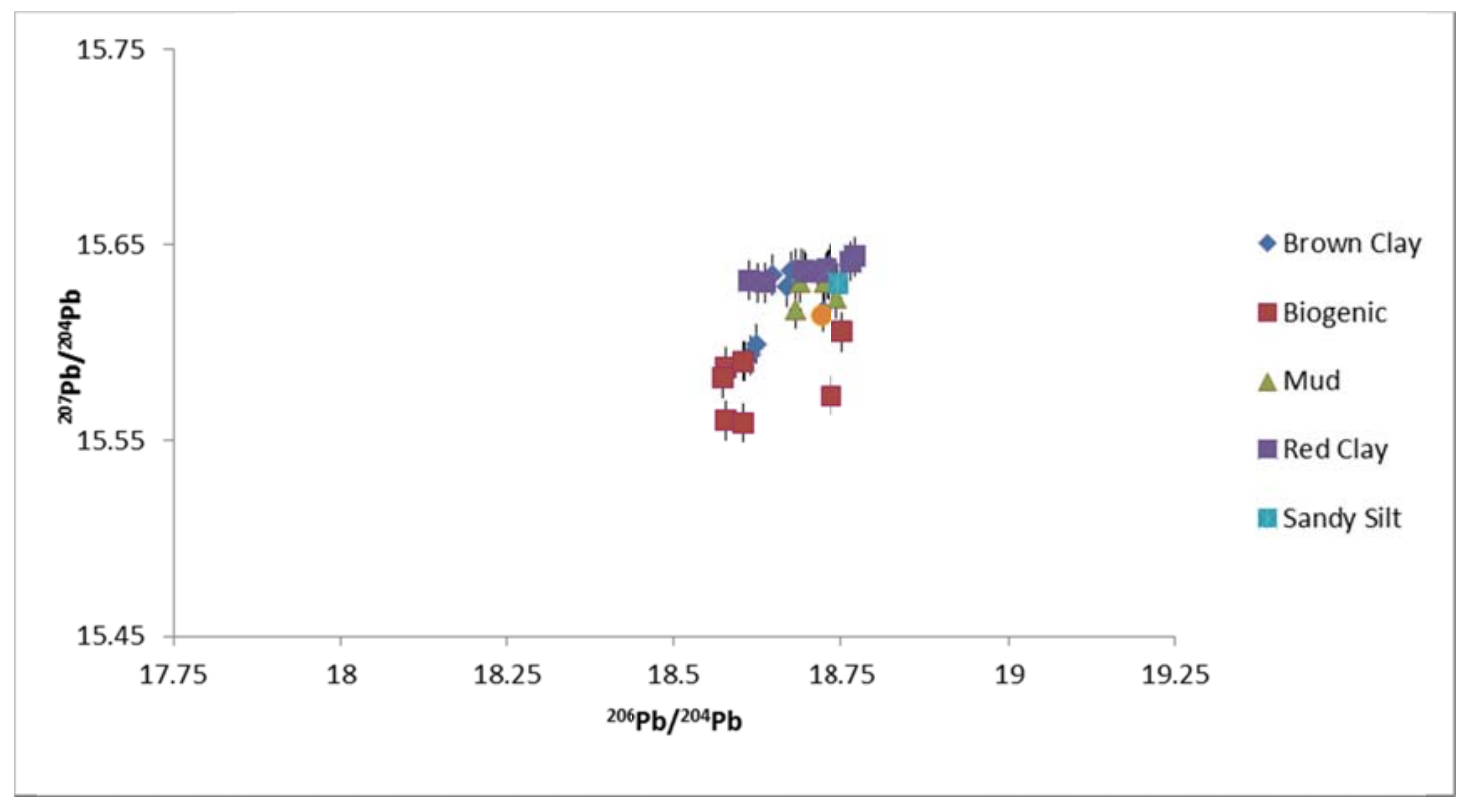

Figure 12b COMPARISON OF SEAFLOOR DATA BY SEDIMENT TYPE ${ }^{207} \mathrm{~Pb} /{ }^{204} \mathrm{~Pb}$ vs. ${ }^{206} \mathrm{~Pb} /{ }^{204} \mathrm{~Pb}$ 


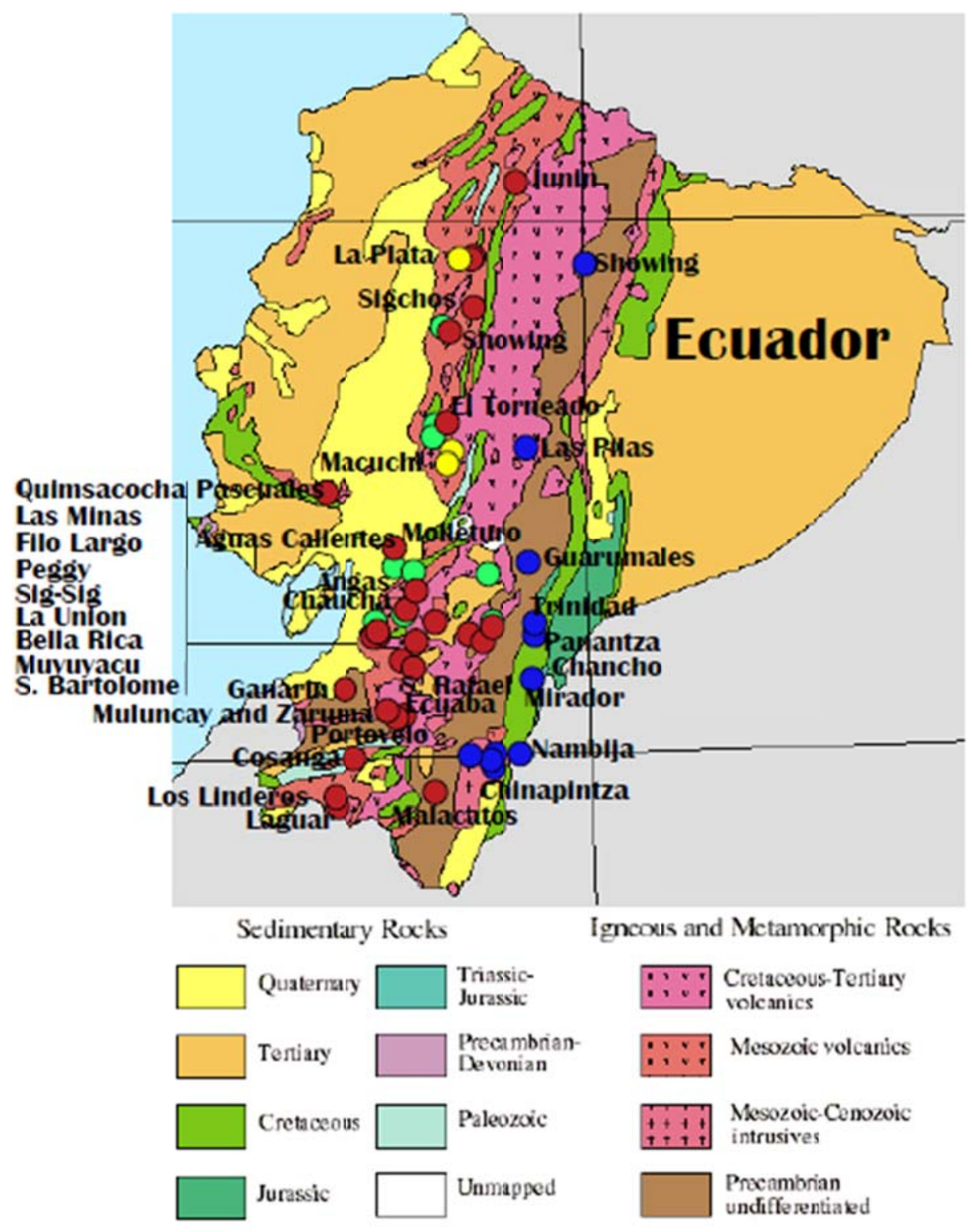

Figure 13 GEOLOGIC MAP OF ECUADOR, showing the age of geologic deposits with an overlay of mine locations for the area of interest, map courtesy of www.andesgoldmine.com. 


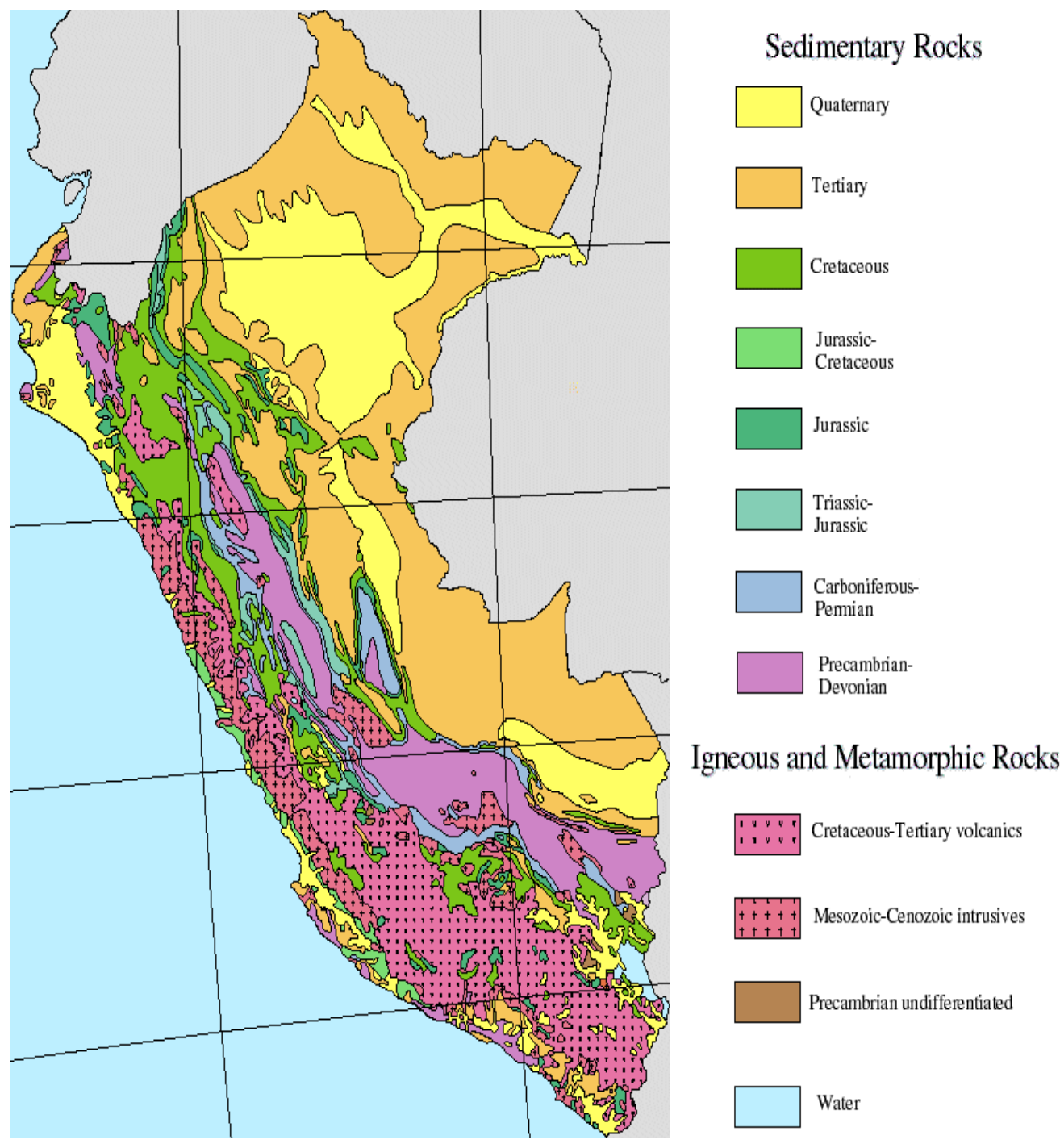

Figure 14 GEOLOGIC MAP OF PERU, showing the age of geologic deposits, map courtesy of www.antimonyworld.com 


\section{LIST OF REFERENCES}

Atherton, M. P., Cobbing, E. J., \& Beckinsale, R. D. (1985). Magmatism at a plate edge: the Peruvian Andes (p. 328). Blackie.

Bowen, R. (1988). Isotopes in the earth sciences. London; New York: Elsevier.

Bourdon, E., Eissen, J.P., Gutscher, M.A., Monzier, M., Hall, M. L., Cotton, J., (2003) Magmatic response to early aseismic ridge subduction: the Ecuadorian margin case (South America). Earth and Planetary Science Letters, 205, 123-138.

California, U. o. (1961). University Bulletin: A Weekly Bulletin for the Staff of the University of California, Office of Official Publications, University of California.

Capitanio, F. A., Faccenna, C., Stegman, D. R., \& Zlotnik, S. (2011). Subduction dynamics and the origin of Andean orogeny and the Bolivian orocline. Nature, 480, $83+$.

Chiaradia, M., \& Fontboté, L. (2001). Radiogenic lead signatures in Au-rich VHMS ores and associated volcanic rocks of the Early Tertiary Macuchi island arc (Western Cordillera of Ecuador). Econ Geol, 96, 1361-1378.

Chiaradia, M., Fontboté, L., \& Beate, B. (2004). Cenozoic continental arc magmatism and associated mineralization in Ecuador. Mineralium Deposita, 39(2), 204-222.

Chiaradia, M., Fontboté, L., \& Paladines, A. (2004). Metal sources in mineral deposits and crustal rocks of Ecuador (1 N-4 S): a lead isotope synthesis. Economic Geology, 99(6), 1085-1106.

Chiaradia, M. (2009). Adakite-like magmas from fractional crystallization and meltingassimilation of mafic lower crust (Eocene Mabuchi arc, western cordillera, Ecuador). Chemical Geology, 265(3-4), 468-487.

Chiaradia, M., Vallance, J., Fontboté, L., Stein, H., Schaltegger, U., Coder, J., \& Gendall, I. (2009). U-Pb, Re-Os, and 40Ar/39Ar geochronology of the Nambija Au-skarn and Pangui porphyry $\mathrm{Cu}$ deposits, Ecuador: Implications for the Jurassic metallogenic belt of the Northern Andes. Mineralium Deposita, 44(4), 371-387.

Chow, T. J., \& Patterson, C. (1962). The occurrence and significance of lead isotopes in pelagic sediments. Geochimica Et Cosmochimica Acta, 26(2), 263-308.

Daly, M. C. (1989). Correlations between Nazca/Farallon plate kinematics and forearc basin evolution in Ecuador. Tectonics, 8(4), 769-790. 
Dasch, E. J. (1981). Lead isotopic composition of metalliferous sediments from the Nazca plate. Geological Society of America Memoirs, 154, 199-210.

Doe, B. R. (1970). Lead isotopes. Berlin, New York: Springer-Verlag.

Faure, G. (1986). Principles of isotope geology (2nd ed.). New York: Wiley.

Feininger, T., \& Bristow, C. R. (1980). Cretaceous and Paleogene geologic history of coastal Ecuador. Geologische Rundschau, 69(3), 849-874.

Fisher, R. L., W. D. C. A., et al. (1958). Preliminary Report on Expedition Downwind, University of California, Scripps Institution of Oceanography, IGY Cruise to the Southeast Pacific, IGY World Data Center A, National Academy of Sciences.

Harmon, R., Barreiro, B., Moorbath, S., Hoefs, J., Francis, P., Thorpe, R., Viglino, J. (1984). Regional O-, Sr-, and $\mathrm{Pb}$-isotope relationships in late Cenozoic calc-alkaline lavas of the Andean cordillera. Journal of the Geological Society, 141(5), 803-822.

Harmon, R. S. Rapela, C. W. (1991). Andean magmatism and its tectonic setting. Boulder, Colo: Geological Society of America.

Hole, M., Saunders, A., Marriner, G., \& Tarney, J. (1984). Subduction of pelagic sediments: Implications for the origin of Ce-anomalous basalts from the Mariana Islands. Journal of the Geological Society, 141(3), 453-472.

Gunnesch, K. A., Baumann, A., \& Gunnesch, M. (1990). Lead isotope variations across the central Peruvian Andes. Economic Geology, 85(7), 1384-1401.

Kamenov, G., Macfarlane, A. W., \& Riciputi, L. (2002). Sources of lead in the San Cristobal, Pulacayo, and Potosi mining districts, Bolivia, and a reevaluation of regional ore lead isotope provinces. Economic Geology, 97(3), 573-592.

Kamenov, G.D., P. Mueller, and M. Perfit (2004), Optimization of mixed Pb-Tl solutions for high precision isotope analyses by MC-ICP-MS, J. Anal. At. Spectrom. 19, 12621267.

Kontak, D. J., Cumming, G. L., Krstic, D., Clark, A. H., \& Farrar, E. (1990). Isotopic composition of lead in ore deposits of the Cordillera Oriental, southeastern Peru. Economic Geology, 85(7), 1584-1603.

Lamb, S., Hoke, L., Kennan, L., \& Dewey, J. (1996). Cenozoic evolution of the central Andes in Bolivia and northern Chile. Special Publication-Geological Society of London, 121, 237-264. 
Lebras, M., Megard, F., Dupuy, C., \& Dostal, J. (1987). Geochemistry and tectonic setting of pre-collision Cretaceous and Paleogene volcanic rocks of Ecuador. Geological Society of America Bulletin, 99(4), 569-578.

Luzieux, L. D. A., Heller, F., Spikings, R., Vallejo, C. F., \& Winkler, W. (2006). Origin and Cretaceous tectonic history of the coastal Ecuadorian forearc between $1 \mathrm{~N}$ and 3 S: Paleomagnetic, radiometric and fossil evidence. Earth and Planetary Science Letters, 249(3), 400-414.

Macfarlane, A., W. (2015). Florida International University, personal correspondence.

Macfarlane, A. W., Marcet, P., LeHuray, A. P., \& Petersen, U. (1990). Lead isotope provinces of the Central Andes inferred from ores and crustal rocks. Economic Geology, 85(8), 1857-1880.

Macfarlane, A. W., \& Petersen, U. (1990). Pb isotopes of the Hualgayoc area, northern Perú; implications for metal provenance and genesis of a cordilleran polymetallic mining district. Economic Geology, 85(7), 1303-1327.

doi:10.2113/gsecongeo.85.7.1303

Macfarlane, A. W., \& Lechtman, H. N. (2014). Andean ores, bronze artifacts, and lead isotopes: Constraints on metal sources in their geological context. Journal of Archaeological Method and Theory, DOI 10.1007/s10816-014-9225-8.

Maksymowicz, A., Contreras-Reyes, E., Grevemeyer, I., \& Flueh, E. R. (2012). Structure and geodynamics of the post-collision zone between the Nazca-Antarctic spreading center and South America. Earth and Planetary Science Letters, 345, 27-37.

Martinod, J., Husson, L., Roperch, P., Guillaume, B., \& Espurt, N. (2010). Horizontal subduction zones, convergence velocity and the building of the Andes. Earth and Planetary Science Letters, 299(3), 299-309.

Meijer, A. (1976). Pb and Sr isotopic data bearing on the origin of volcanic rocks from the Mariana island-arc system. Geological Society of America Bulletin, 87(9), 13581369.

Miller, D. M., Goldstein, S. L., \& Langmuir, C. H. (1994). Cerium/lead and lead isotope ratios in arc magmas and the enrichment of lead in the continents. Nature, 368(6471), 514-520.

Mukasa, S. B., \& Injoque-Espinoza, J. (1990). Pb isotope bearing on the metallogenesis of sulfide ore deposits in central and southern Peru. Economic Geology, 85(7), 14381446. 
Peucker-Ehrenbrink, B., Hofmann, A., \& Hart, S. (1994). Hydrothermal lead transfer from mantle to continental crust: The role of metalliferous sediments. Earth and Planetary Science Letters, 125(1), 129-142.

Plank, T., \& Langmuir, C. H. (1993). Tracing trace elements from sediment input to volcanic output at subduction zones. Nature, 362(6422), 739-743.

Reynolds, P. H., \& Dasch, E. J. (1971). Lead isotopes in marine manganese nodules and the ore-lead growth curve. Journal of Geophysical Research, 76(21), 5124-5129.

Tosdal, R. M. (1996). The Amazon-Laurentian connection as viewed from the Middle Proterozoic rocks in the central Andes, western Bolivia and northern Chile. Tectonics, 15(4), 827-842.

Unruh, D., \& Tatsumoto, M. (1976). Lead isotopic composition and uranium, thorium, and lead concentrations in sediments and basalts from the Nazca plate. Initial Rep.Deep Sea Drill.Proj, 34, 341-347.

Van Hunen, J., Van Den BERG, Arie P, \& Vlaar, N. J. (2002). On the role of subducting oceanic plateaus in the development of shallow flat subduction. Tectonophysics, 352(3), 317-333.

White, W. M., \& Dupré, B. (1986). Sediment subduction and magma genesis in the Lesser Antilles: Isotopic and trace element constraints. Journal of Geophysical Research: Solid Earth (1978-2012), 91(B6), 5927-5941.

White, K. (1994). Florida International University, unpublished Thesis data.

Woollard, G. P., Klum, L. D., (1981). Nazca plate: Crustal formation and Andean convergence: A volume dedicated to George P. Woollard. Boulder, CO: Geological Society of America.

Zartman, R., \& Doe, B. (1981). Plumbotectonics - the model. Tectonophysics, 75(1), 135-162. 
APPENDIX I. Sample Descriptions

\begin{tabular}{|c|c|c|c|c|c|}
\hline Sample \# & Location & $\begin{array}{l}\text { Depth in } \\
\text { core }\end{array}$ & $\begin{array}{l}\text { Depth } \\
\text { (Meters) }\end{array}$ & $\begin{array}{l}\text { Weight } \\
\text { taken }\end{array}$ & $\begin{array}{l}\text { Sediment } \\
\text { Description }\end{array}$ \\
\hline $\begin{array}{l}\text { DWBG } 101 \\
\# 1\end{array}$ & $\begin{array}{l}16^{\circ} 03^{\prime} \mathrm{S} \\
78^{\circ} 56^{\prime} \mathrm{W}\end{array}$ & $34-37 \mathrm{~cm}$ & $4280 M$ & $586.39 \mathrm{mg}$ & $\begin{array}{l}\text { Sed. Type R, } \\
\text { Moderately } \\
\text { dry, Red clay } \\
\text { overlying } \\
\text { bluish-green } \\
\text { clay }\end{array}$ \\
\hline $\begin{array}{l}\text { DWBG } 101 \\
\# 2\end{array}$ & $\begin{array}{l}16^{\circ} 03^{\prime} \mathrm{S}, \\
78^{\circ} 56^{\prime} \mathrm{W}\end{array}$ & $75-77 \mathrm{~cm}$ & $4280 M$ & $563.69 \mathrm{mg}$ & $\begin{array}{l}\text { Sed. Type R, } \\
\text { Moderately } \\
\text { dry, Red clay } \\
\text { overlying } \\
\text { bluish-green } \\
\text { clay }\end{array}$ \\
\hline $\begin{array}{l}\text { DWBG } 102 \\
\# 1\end{array}$ & $\begin{array}{l}13^{\circ} 36^{\prime} \mathrm{S} \\
79^{\circ} 07^{\prime} \mathrm{W}\end{array}$ & $37-40 \mathrm{~cm}$ & $4495 \mathrm{M}$ & $491.81 \mathrm{mg}$ & $\begin{array}{l}\text { Sed. Type M, } \\
\text { Moist, Red } \\
\text { clay overlying } \\
\text { bluish-green } \\
\text { clay }\end{array}$ \\
\hline $\begin{array}{l}\text { DWBG } 102 \\
\# 2\end{array}$ & $\begin{array}{l}13^{\circ} 36^{\prime} \mathrm{S}, \\
79^{\circ} 07^{\prime} \mathrm{W}\end{array}$ & $113-116 \mathrm{~cm}$ & $4495 \mathrm{M}$ & $528.89 \mathrm{mg}$ & $\begin{array}{l}\text { Sed. Type M, } \\
\text { Moderately } \\
\text { dry, Red clay } \\
\text { overlying } \\
\text { bluish-green } \\
\text { clay }\end{array}$ \\
\hline DWBG 109 & $\begin{array}{l}13^{\circ} 02^{\prime} \mathrm{S}, \\
78^{\circ} 20^{\prime} \mathrm{W}\end{array}$ & $52.5-55.5 \mathrm{~cm}$ & $5860 \mathrm{M}$ & $539.73 \mathrm{mg}$ & $\begin{array}{l}\text { Sed. Type R, } \\
\text { Moist, Dark } \\
\text { greenish mud, } \\
\text { browner at top }\end{array}$ \\
\hline $\begin{array}{l}\text { DWBG 115B } \\
\# 1\end{array}$ & $\begin{array}{l}19^{\circ} 0^{\prime} \mathrm{S}, \\
81^{\circ} 27^{\prime} \mathrm{W}\end{array}$ & $39-42 \mathrm{~cm}$ & $4340 \mathrm{M}$ & $507.79 \mathrm{mg}$ & $\begin{array}{l}\text { Sed. Type M, } \\
\text { Moderately } \\
\text { moist, } \\
\text { Brownish clay } \\
\text { with lighter } \\
\text { zones }\end{array}$ \\
\hline $\begin{array}{l}\text { DWBG 115B } \\
\# 2\end{array}$ & $\begin{array}{l}19^{\circ} 0^{\prime} \mathrm{S}, \\
81^{\circ} 27^{\prime} \mathrm{W}\end{array}$ & $88-91 \mathrm{~cm}$ & $4340 \mathrm{M}$ & $550.00 \mathrm{mg}$ & $\begin{array}{l}\text { Sed. Type M, } \\
\text { Moderately } \\
\text { moist, } \\
\text { Brownish clay } \\
\text { with lighter } \\
\text { zones } \\
\end{array}$ \\
\hline
\end{tabular}




\begin{tabular}{|c|c|c|c|c|c|}
\hline $\begin{array}{l}\text { DWBG 115B } \\
\# 3\end{array}$ & $\begin{array}{l}19^{\circ} 0^{\prime} \mathrm{S} \\
81^{\circ} 27^{\prime} \mathrm{W}\end{array}$ & $137-140 \mathrm{~cm}$ & $4340 \mathrm{M}$ & $526.61 \mathrm{mg}$ & $\begin{array}{l}\text { Sed. Type M, } \\
\text { Moderately } \\
\text { moist, } \\
\text { Brownish clay } \\
\text { with lighter } \\
\text { zones }\end{array}$ \\
\hline DWBG 117A & $\begin{array}{l}27^{\circ} 05^{\prime} \mathrm{S} \\
88^{\circ} 53^{\prime} \mathrm{W}\end{array}$ & $12-15 \mathrm{~cm}$ & $3780 \mathrm{M}$ & $501.01 \mathrm{mg}$ & $\begin{array}{l}\text { Sed. Type S, } \\
\text { Very dry }\end{array}$ \\
\hline DWBG 118C & $\begin{array}{l}28^{\circ} 02^{\prime} \mathrm{S}, \\
96^{\circ} 20^{\prime} \mathrm{W}\end{array}$ & $64-67 \mathrm{~cm}$ & $3400 M$ & $526.45 \mathrm{mg}$ & $\begin{array}{l}\text { Sed. Type S, } \\
\text { Moderately } \\
\text { dry, Red } \\
\text { foraminiferal } \\
\text { clay }\end{array}$ \\
\hline DWBG 121 & $\begin{array}{l}27^{\circ} 09^{\prime} \mathrm{S}, \\
109^{\circ} 50^{\prime} \mathrm{W}\end{array}$ & $63-66 \mathrm{~cm}$ & & $502.46 \mathrm{mg}$ & $\begin{array}{l}\text { Sed. Type S, } \\
\text { Very dry, } \\
\text { Brown } \\
\text { foraminiferal } \\
\text { clay }\end{array}$ \\
\hline DWBG 83 & $\begin{array}{l}44^{\circ} 04^{\prime} \mathrm{S}, \\
95^{\circ} 52^{\prime} \mathrm{W}\end{array}$ & $108-112 \mathrm{~cm}$ & $4660 \mathrm{M}$ & $501.25 \mathrm{mg}$ & $\begin{array}{l}\text { Sed. Type S, } \\
\text { Moderately } \\
\text { dry, Light } \\
\text { brown sandy } \\
\text { silt overlying } \\
\text { darker brown }\end{array}$ \\
\hline $\begin{array}{l}\text { DWBG 97B } \\
\# 1\end{array}$ & $\begin{array}{l}21^{\circ} 32^{\prime} \mathrm{S}, \\
79^{\circ} 10^{\prime} \mathrm{W}\end{array}$ & $43-47 \mathrm{~cm}$ & $4485 \mathrm{M}$ & $551.84 \mathrm{mg}$ & $\begin{array}{l}\text { Sed. Type S, } \\
\text { Moderately } \\
\text { moist, Small } \\
\text { amount of red } \\
\text { clay }\end{array}$ \\
\hline $\begin{array}{l}\text { DWBG 97B } \\
\# 2\end{array}$ & $\begin{array}{l}21^{\circ} 32^{\prime} \mathrm{S} \\
79^{\circ} 10^{\prime} \mathrm{W}\end{array}$ & $93-96 \mathrm{~cm}$ & $4485 \mathrm{M}$ & $516.43 \mathrm{mg}$ & $\begin{array}{l}\text { Sed. Type S, } \\
\text { Moderately } \\
\text { moist, Small } \\
\text { amount of red } \\
\text { clay }\end{array}$ \\
\hline DWH G56 \#1 & $\begin{array}{l}37^{\circ} 03^{\prime} \mathrm{S}, \\
81^{\circ} 50^{\prime} \mathrm{W}\end{array}$ & $46-49 \mathrm{~cm}$ & 3994M & $542.12 \mathrm{mg}$ & $\begin{array}{l}\text { Sed. Type S, } \\
\text { Moist, Dark } \\
\text { brown clay }\end{array}$ \\
\hline DWH G56 \#2 & $\begin{array}{l}37^{\circ} 03^{\prime} \mathrm{S} \\
81^{\circ} 50^{\prime} \mathrm{W}\end{array}$ & $70-73 \mathrm{~cm}$ & 3994M & $560.73 \mathrm{mg}$ & $\begin{array}{l}\text { Sed. Type S, } \\
\text { Moist, Dark } \\
\text { brown clay }\end{array}$ \\
\hline DWH G56 \#3 & $\begin{array}{l}37^{\circ} 03^{\prime} \mathrm{S} \\
81^{\circ} 50^{\prime} \mathrm{W}\end{array}$ & $106-109 \mathrm{~cm}$ & 3994M & $501.83 \mathrm{mg}$ & $\begin{array}{l}\text { Sed. Type S, } \\
\text { Dry, Dark } \\
\text { brown clay }\end{array}$ \\
\hline DWHG 67 & $\begin{array}{l}22^{\circ} 30^{\prime} \mathrm{S} \\
78^{\circ} 29^{\prime} \mathrm{W}\end{array}$ & $36-39 \mathrm{~cm}$ & $4740 \mathrm{M}$ & $561.15 \mathrm{mg}$ & $\begin{array}{l}\text { Sed. Type S, } \\
\text { Moderately } \\
\text { moist, Brown }\end{array}$ \\
\hline
\end{tabular}




\begin{tabular}{|c|c|c|c|c|c|}
\hline & & & & & clay \\
\hline DWHG 69 \#1 & $\begin{array}{l}17^{\circ} 10^{\prime} \mathrm{S}, \\
77^{\circ} 01^{\prime} \mathrm{W}\end{array}$ & $41-44 \mathrm{~cm}$ & $3500 \mathrm{M}$ & $510.68 \mathrm{mg}$ & $\begin{array}{l}\text { Sed. Type M, } \\
\text { Moderately } \\
\text { dry, Brown } \\
\text { clay overlying } \\
\text { blue-grey clay }\end{array}$ \\
\hline DWHG 69\#2 & $\begin{array}{l}17^{\circ} 10^{\prime} \mathrm{S}, \\
77^{\circ} 01^{\prime} \mathrm{W}\end{array}$ & $53-55 \mathrm{~cm}$ & $3500 \mathrm{M}$ & $529.27 \mathrm{mg}$ & $\begin{array}{l}\text { Sed. Type M, } \\
\text { Moderately } \\
\text { moist, Brown } \\
\text { clay overlying } \\
\text { blue-grey clay }\end{array}$ \\
\hline DWHG 70 & $\begin{array}{l}14^{\circ} 18^{\prime} \mathrm{S}, \\
78^{\circ} 18^{\prime} \mathrm{W}\end{array}$ & $62-65 \mathrm{~cm}$ & $4300 \mathrm{M}$ & $525.76 \mathrm{mg}$ & $\begin{array}{l}\text { Sed. Type M, } \\
\text { Moist, Olive } \\
\text { clay }\end{array}$ \\
\hline DWHG $79 \# 1$ & $\begin{array}{l}23^{\circ} 37^{\prime} \mathrm{S} \\
118^{\circ} 14^{\prime} \mathrm{W}\end{array}$ & $57-60 \mathrm{~cm}$ & $3440 \mathrm{M}$ & $505.54 \mathrm{mg}$ & $\begin{array}{l}\text { Sed. Type S, } \\
\text { Moderately } \\
\text { dry, Dark } \\
\text { brown } \\
\text { calcareous } \\
\text { ooze }\end{array}$ \\
\hline DWHG 79 \#2 & $\begin{array}{l}23^{\circ} 37^{\prime} \mathrm{S}, \\
118^{\circ} 14^{\prime} \mathrm{W}\end{array}$ & $113-115 \mathrm{~cm}$ & $3440 \mathrm{M}$ & $583.23 \mathrm{mg}$ & $\begin{array}{l}\text { Sed. Type S, } \\
\text { Moderately } \\
\text { dry, Dark } \\
\text { brown } \\
\text { calcareous } \\
\text { ooze }\end{array}$ \\
\hline DWHT 49B & $\begin{array}{l}40^{\circ} 02^{\prime} \mathrm{S}, \\
98^{\circ} 04^{\prime} \mathrm{W}\end{array}$ & $58-60 \mathrm{~cm}$ & $4350 \mathrm{M}$ & $561.31 \mathrm{mg}$ & $\begin{array}{l}\text { Sed. Type S, } \\
\text { Moist, } \\
\text { Chocolate clay }\end{array}$ \\
\hline DWHG G54 & $\begin{array}{l}38^{\circ} 49^{\prime} \mathrm{S}, \\
83^{\circ} 21^{\prime} \mathrm{W}\end{array}$ & $36-39 \mathrm{~cm}$ & $4080 \mathrm{M}$ & $514.86 \mathrm{mg}$ & $\begin{array}{l}\text { Sed. Type S, } \\
\text { Dark brown, } \\
\text { Chocolate } \\
\text { foraminiferal } \\
\text { clay overlying } \\
\text { yellowish clay }\end{array}$ \\
\hline $\begin{array}{l}\text { DWHG G54 } \\
\text { REDO }\end{array}$ & $\begin{array}{l}38^{\circ} 49^{\prime} \mathrm{S}, \\
83^{\circ} 21^{\prime} \mathrm{W}\end{array}$ & $36-39 \mathrm{~cm}$ & $4080 \mathrm{M}$ & $500.79 \mathrm{mg}$ & $\begin{array}{l}\text { Sed. Type S, } \\
\text { Dark brown, } \\
\text { Chocolate } \\
\text { foraminiferal } \\
\text { clay overlying } \\
\text { yellowish clay } \\
\end{array}$ \\
\hline RIS 40G \#1 & $\begin{array}{l}12^{\circ} 58^{\prime} \mathrm{S} \\
81^{\circ} 31^{\prime} \mathrm{W}\end{array}$ & $40-43 \mathrm{~cm}$ & & $507.88 \mathrm{mg}$ & $\begin{array}{l}\text { Sed. Type S, } \\
\text { Moderately } \\
\text { moist, Red clay }\end{array}$ \\
\hline
\end{tabular}




\begin{tabular}{|c|c|c|c|c|c|}
\hline & & & $4840 \mathrm{M}$ & & $\begin{array}{l}\text { with a small } \\
\text { amount of } \\
\text { green-gray } \\
\text { clay }\end{array}$ \\
\hline RIS 40G \#2 & $\begin{array}{l}12^{\circ} 58^{\prime} \mathrm{S} \\
81^{\circ} 31^{\prime} \mathrm{W}\end{array}$ & $124-127 \mathrm{~cm}$ & $4840 \mathrm{M}$ & $502.69 \mathrm{mg}$ & $\begin{array}{l}\text { Sed. Type S, } \\
\text { Moderately } \\
\text { moist, Red clay } \\
\text { with a small } \\
\text { amount of } \\
\text { green-gray } \\
\text { clay }\end{array}$ \\
\hline RIS 42G \#1 & $\begin{array}{l}13^{\circ} 11^{\prime} \mathrm{S}, \\
84^{\circ} 24^{\prime} \mathrm{W}\end{array}$ & $47-50 \mathrm{~cm}$ & $4740 \mathrm{M}$ & $511.86 \mathrm{mg}$ & $\begin{array}{l}\text { Sed. Type S, } \\
\text { Moderately } \\
\text { dry, Light and } \\
\text { dark brown } \\
\text { clay }\end{array}$ \\
\hline RIS 42G \#2 & $\begin{array}{l}13^{\circ} 11^{\prime} \mathrm{S}, \\
84^{\circ} 24^{\prime} \mathrm{W}\end{array}$ & $108-111 \mathrm{~cm}$ & $4740 \mathrm{M}$ & $510.28 \mathrm{mg}$ & $\begin{array}{l}\text { Sed. Type S, } \\
\text { Light and dark } \\
\text { brown clay }\end{array}$ \\
\hline RIS 44G \#1 & $\begin{array}{l}13^{\circ} 31^{\prime} \mathrm{S}, \\
88^{\circ} 26^{\prime} \mathrm{W}\end{array}$ & $56-58 \mathrm{~cm}$ & $4240 \mathrm{M}$ & $492.90 \mathrm{mg}$ & $\begin{array}{l}\text { Sed. Type S, } \\
\text { Moderately } \\
\text { moist, Light } \\
\text { and dark } \\
\text { brown mud }\end{array}$ \\
\hline RIS 44G \#2 & $\begin{array}{l}13^{\circ} 31^{\prime} \mathrm{S}, \\
88^{\circ} 26^{\prime} \mathrm{W}\end{array}$ & $101-103 \mathrm{~cm}$ & $4240 \mathrm{M}$ & $510.30 \mathrm{mg}$ & $\begin{array}{l}\text { Sed. Type S, } \\
\text { Moderately } \\
\text { moist, Light } \\
\text { and dark } \\
\text { brown mud }\end{array}$ \\
\hline RIS 48G \#1 & $\begin{array}{l}13^{\circ} 34^{\prime} \mathrm{S}, \\
93^{\circ} 28^{\prime} \mathrm{W}\end{array}$ & $34-37 \mathrm{~cm}$ & $3900 \mathrm{M}$ & $512.15 \mathrm{mg}$ & $\begin{array}{l}\text { Sed. Type MS, } \\
\text { Moderately } \\
\text { Dry, Medium } \\
\text { brown clay } \\
\text { slightly } \\
\text { calcareous }\end{array}$ \\
\hline RIS 48G \#2 & $\begin{array}{l}13^{\circ} 34^{\prime} \mathrm{S}, \\
93^{\circ} 28^{\prime} \mathrm{W}\end{array}$ & $84-86 \mathrm{~cm}$ & $3900 \mathrm{M}$ & $505.21 \mathrm{mg}$ & $\begin{array}{l}\text { Sed. Type MS, } \\
\text { Moderately } \\
\text { Dry, Medium } \\
\text { brown clay } \\
\text { slightly } \\
\text { calcareous }\end{array}$ \\
\hline RIS 50G & $\begin{array}{l}13^{\circ} 36^{\prime} \mathrm{S}, \\
96^{\circ} 42^{\prime} \mathrm{W}\end{array}$ & $67-70 \mathrm{~cm}$ & $4120 \mathrm{M}$ & $507.70 \mathrm{mg}$ & $\begin{array}{l}\text { Sed. Type S, } \\
\text { Moderately } \\
\text { dry, Brown to } \\
\text { yellow-brown } \\
\text { mud }\end{array}$ \\
\hline
\end{tabular}




\begin{tabular}{|c|c|c|c|c|c|}
\hline RIS 52G & $\begin{array}{l}13^{\circ} 24^{\prime} \mathrm{S}, \\
100^{\circ} 29^{\prime} \mathrm{W}\end{array}$ & $\begin{array}{l}0-30 \mathrm{~cm} \\
\text { interval }\end{array}$ & $4210 \mathrm{M}$ & $524.01 \mathrm{mg}$ & $\begin{array}{l}\text { Sed. Type S, } \\
\text { Chocolate } \\
\text { brown mud } \\
\text { slightly } \\
\text { calcareous at } \\
\text { bottom }\end{array}$ \\
\hline
\end{tabular}


APPENDIX II. Data table reporting all data established in the current study.

\begin{tabular}{|c|c|c|c|c|c|c|}
\hline Sample & $208 / 204$ & $207 / 204$ & $206 / 204$ & Coordinates & Depth in core & Amount dissolved \\
\hline DWBG101\#134-37' & 38.72538 & 15.63612 & 18.69527 & $16^{\circ} 03^{\prime} \mathrm{S}, 78^{\circ} 56^{\prime} \mathrm{W}$ & $34-37 \mathrm{~cm}$ & $586.39 \mathrm{mg}$ \\
\hline DWBG101\#275-77' & 38.73634 & 15.63602 & 18.72584 & $16^{\circ} 03^{\prime} \mathrm{S}, 78^{\circ} 56^{\prime} \mathrm{W}$ & $75-77 \mathrm{~cm}$ & $563.69 \mathrm{mg}$ \\
\hline DWBG102\#137-40' & 38.73479 & 15.63736 & 18.72937 & $13^{\circ} 36^{\prime} \mathrm{S}, 79^{\circ} 07^{\prime} \mathrm{W}$ & $37-40 \mathrm{~cm}$ & $491.81 \mathrm{mg}$ \\
\hline DWBG102\#2113-116' & 38.72465 & 15.63699 & 18.69502 & $13^{\circ} 36^{\prime} \mathrm{S}, 79^{\circ} 07^{\prime} \mathrm{W}$ & $113-116 \mathrm{~cm}$ & $528.89 \mathrm{mg}$ \\
\hline DWBG10952.5-55.5' & 38.67926 & 15.62274 & 18.74466 & $13^{\circ} 02^{\prime} \mathrm{S}, 78^{\circ} 20^{\prime} \mathrm{W}$ & $52.5-55.5 \mathrm{~cm}$ & $539.73 \mathrm{mg}$ \\
\hline DWBG115B\#139-42' & 38.71804 & 15.63683 & 18.67498 & $19^{\circ} 0^{\prime} \mathrm{S}, 81^{\circ} 27^{\prime} \mathrm{W}$ & $39-42 \mathrm{~cm}$ & $507.79 \mathrm{mg}$ \\
\hline DWBG115B\#288-91' & 38.69314 & 15.62897 & 18.66827 & $19^{\circ} 0^{\prime} \mathrm{S}, 81^{\circ} 27^{\prime} \mathrm{W}$ & $88-91 \mathrm{~cm}$ & $550.00 \mathrm{mg}$ \\
\hline DWBG115B\#3137-140' & 38.72505 & 15.63782 & 18.68025 & $19^{\circ} 0^{\prime} \mathrm{S}, 81^{\circ} 27^{\prime} \mathrm{W}$ & $137-140 \mathrm{~cm}$ & $526.61 \mathrm{mg}$ \\
\hline DWBG117A12-15' & 38.57819 & 15.61412 & 18.71948 & $27^{\circ} 05^{\prime} \mathrm{S}, 88^{\circ} 53^{\prime} \mathrm{W}$ & $12-15 \mathrm{~cm}$ & $501.01 \mathrm{mg}$ \\
\hline DWBG118C64-67' & 38.53627 & 15.60586 & 18.75238 & $28^{\circ} 02^{\prime} \mathrm{S}, 96^{\circ} 20^{\prime} \mathrm{W}$ & $64-67 \mathrm{~cm}$ & $526.45 \mathrm{mg}$ \\
\hline DWBG12163-66' & 38.38123 & 15.57327 & 18.73616 & $27^{\circ} 09^{\prime} \mathrm{S}, 109^{\circ} 50^{\prime} \mathrm{W}$ & $63-66 \mathrm{~cm}$ & $502.46 \mathrm{mg}$ \\
\hline DWBG83108-112' & 38.655 & 15.6303 & 18.74622 & $44^{\circ} 04^{\prime} \mathrm{S}, 95^{\circ} 52^{\prime} \mathrm{W}$ & $108-112 \mathrm{~cm}$ & $501.25 \mathrm{mg}$ \\
\hline DWBG97B\#143-47' & 38.68092 & 15.63075 & 18.63539 & $21^{\circ} 32^{\prime} \mathrm{S}, 79^{\circ} 10^{\prime} \mathrm{W}$ & $43-47 \mathrm{~cm}$ & $551.84 \mathrm{mg}$ \\
\hline DWBG97B\#293-96' & 38.68536 & 15.63197 & 18.6121 & $21^{\circ} 32^{\prime} \mathrm{S}, 79^{\circ} 10^{\prime} \mathrm{W}$ & $93-96 \mathrm{~cm}$ & $516.43 \mathrm{mg}$ \\
\hline DWHG56\#146-49' & 38.44754 & 15.59985 & 18.62245 & $37^{\circ} 03^{\prime} \mathrm{S}, 81^{\circ} 50^{\prime} \mathrm{W}$ & $46-49 \mathrm{~cm}$ & $542.12 \mathrm{mg}$ \\
\hline DWHG56\#270-73' & 38.41443 & 15.59424 & 18.61371 & $37^{\circ} 03^{\prime} \mathrm{S}, 81^{\circ} 50^{\prime} \mathrm{W}$ & $70-73 \mathrm{~cm}$ & $560.73 \mathrm{mg}$ \\
\hline DWHG56\#3106-109' & 38.38544 & 15.59088 & 18.60529 & $37^{\circ} 03^{\prime} \mathrm{S}, 81^{\circ} 50^{\prime} \mathrm{W}$ & $106-109 \mathrm{~cm}$ & $501.83 \mathrm{mg}$ \\
\hline DWHG6736-39' & 38.68193 & 15.631 & 18.62552 & $22^{\circ} 30^{\prime} \mathrm{S}, 78^{\circ} 29^{\prime} \mathrm{W}$ & $36-39 \mathrm{~cm}$ & $561.15 \mathrm{mg}$ \\
\hline DWHG69\#253-55' & 38.71066 & 15.63483 & 18.64646 & $17^{\circ} 10^{\prime} \mathrm{S}, 77^{\circ} 01^{\prime} \mathrm{W}$ & $53-55 \mathrm{~cm}$ & $529.27 \mathrm{mg}$ \\
\hline DWHG6941-44' & 38.70126 & 15.63047 & 18.63499 & $17^{\circ} 10^{\prime} \mathrm{S}, 77^{\circ} 01^{\prime} \mathrm{W}$ & $41-44 \mathrm{~cm}$ & $510.68 \mathrm{mg}$ \\
\hline DWHG7062-65' & 38.7357 & 15.63797 & 18.69044 & $14^{\circ} 18^{\prime} \mathrm{S}, 78^{\circ} 18^{\prime} \mathrm{W}$ & $62-65 \mathrm{~cm}$ & $525.76 \mathrm{mg}$ \\
\hline DWHG79\#157-60' & 38.24608 & 15.56059 & 18.57708 & $23^{\circ} 37^{\prime} \mathrm{S}, 118^{\circ} 14^{\prime} \mathrm{W}$ & $57-60 \mathrm{~cm}$ & $505.54 \mathrm{mg}$ \\
\hline DWHG79\#2113-115' & 38.25746 & 15.55933 & 18.6043 & $23^{\circ} 37^{\prime} \mathrm{S}, 118^{\circ} 14^{\prime} \mathrm{W}$ & $113-115 \mathrm{~cm}$ & $23 \mathrm{mg}$ \\
\hline DWHT49B58-60' & 38.576 & 15.6162 & 18.72169 & $40^{\circ} 02^{\prime} \mathrm{S}, 98^{\circ} 04^{\prime} \mathrm{W}$ & $58-60 \mathrm{~cm}$ & $561.31 \mathrm{mg}$ \\
\hline DWHTG5436-39' & 38.35338 & 15.58782 & 18.57739 & $38^{\circ} 49^{\prime} \mathrm{S}, 83^{\circ} 21^{\prime} \mathrm{W}$ & $36-39 \mathrm{~cm}$ & $514.86 \mathrm{mg}$ \\
\hline DWHTG5436-39R' & 38.33926 & 15.58268 & 18.57401 & $38^{\circ} 49^{\prime} \mathrm{S}, 83^{\circ} 21^{\prime} \mathrm{W}$ & $36-39 \mathrm{~cm}$ & $500.79 \mathrm{mg}$ \\
\hline RIS40G\#140-43' & 38.75941 & 15.64419 & 18.7719 & $12^{\circ} 58^{\prime} \mathrm{S}, 81^{\circ} 31^{\prime} \mathrm{W}$ & $40-43 \mathrm{~cm}$ & $507.88 \mathrm{mg}$ \\
\hline RIS40G\#2124-128' & 38.7513 & 15.64151 & 18.76509 & $12^{\circ} 58^{\prime} \mathrm{S}, 81^{\circ} 31^{\prime} \mathrm{W}$ & $124-127 \mathrm{~cm}$ & $502.69 \mathrm{mg}$ \\
\hline RIS42G\#147-50' & 38.73705 & 15.63985 & 18.73306 & $13^{\circ} 11^{\prime} \mathrm{S}, 84^{\circ} 24^{\prime} \mathrm{W}$ & $47-50 \mathrm{~cm}$ & $511.86 \mathrm{mg}$ \\
\hline RIS42G\#2108-111' & 38.73281 & 15.63748 & 18.73113 & $13^{\circ} 11^{\prime} \mathrm{S}, 84^{\circ} 24^{\prime} \mathrm{W}$ & $108-111 \mathrm{~cm}$ & $510.28 \mathrm{mg}$ \\
\hline RIS44G\#156-58' & 38.68423 & 15.63087 & 18.7235 & $13^{\circ} 31^{\prime} \mathrm{S}, 88^{\circ} 26^{\prime} \mathrm{W}$ & $56-58 \mathrm{~cm}$ & $492.90 \mathrm{mg}$ \\
\hline RIS44G\#2101-103' & 38.66191 & 15.6309 & 18.68678 & $13^{\circ} 31^{\prime} \mathrm{S}, 88^{\circ} 26^{\prime} \mathrm{W}$ & $101-103 \mathrm{~cm}$ & $510.30 \mathrm{mg}$ \\
\hline RIS48G\#134-37' & 38.68837 & 15.6324 & 18.7311 & $13^{\circ} 34^{\prime} \mathrm{S}, 93^{\circ} 28^{\prime} \mathrm{W}$ & $34-37 \mathrm{~cm}$ & $512.15 \mathrm{mg}$ \\
\hline RIS48G\#284-86' & 38.68587 & 15.63312 & 18.72801 & $13^{\circ} 34^{\prime} \mathrm{S}, 93^{\circ} 28^{\prime} \mathrm{W}$ & $84-86 \mathrm{~cm}$ & $505.21 \mathrm{mg}$ \\
\hline RIS50G67-70' & 38.59808 & 15.61725 & 18.68108 & $13^{\circ} 36^{\prime} \mathrm{S}, 96^{\circ} 42^{\prime} \mathrm{W}$ & $67-70 \mathrm{~cm}$ & $507.70 \mathrm{mg}$ \\
\hline RIS52G0-30' & 38.44617 & 15.59102 & 18.60383 & $13^{\circ} 24^{\prime} \mathrm{S}, 100^{\circ} 29^{\prime} \mathrm{W}$ & $0-30 \mathrm{~cm}$ interval & $524.01 \mathrm{mg}$ \\
\hline SPIKE\#1' & 7428.495 & 18.6355 & 27.09308 & & & \\
\hline SPIKE\#2' & 36949.53 & 30.22753 & 49.41038 & & & \\
\hline SPIKE\#3' & 18189.93 & 22.18401 & 33.11721 & & & \\
\hline SPIKE\#4' & 32560.1 & 28.51958 & 45.76176 & & & \\
\hline SPIKE\#5' & 24589.88 & 24.20171 & 38.17836 & & & \\
\hline SPIKE\#6' & 31266.04 & 26.74033 & 43.80844 & & & \\
\hline
\end{tabular}


APPENDIX III. Smear Slide Pictures: Taken in 50x magnification using plain polarized and crossed polarized light.
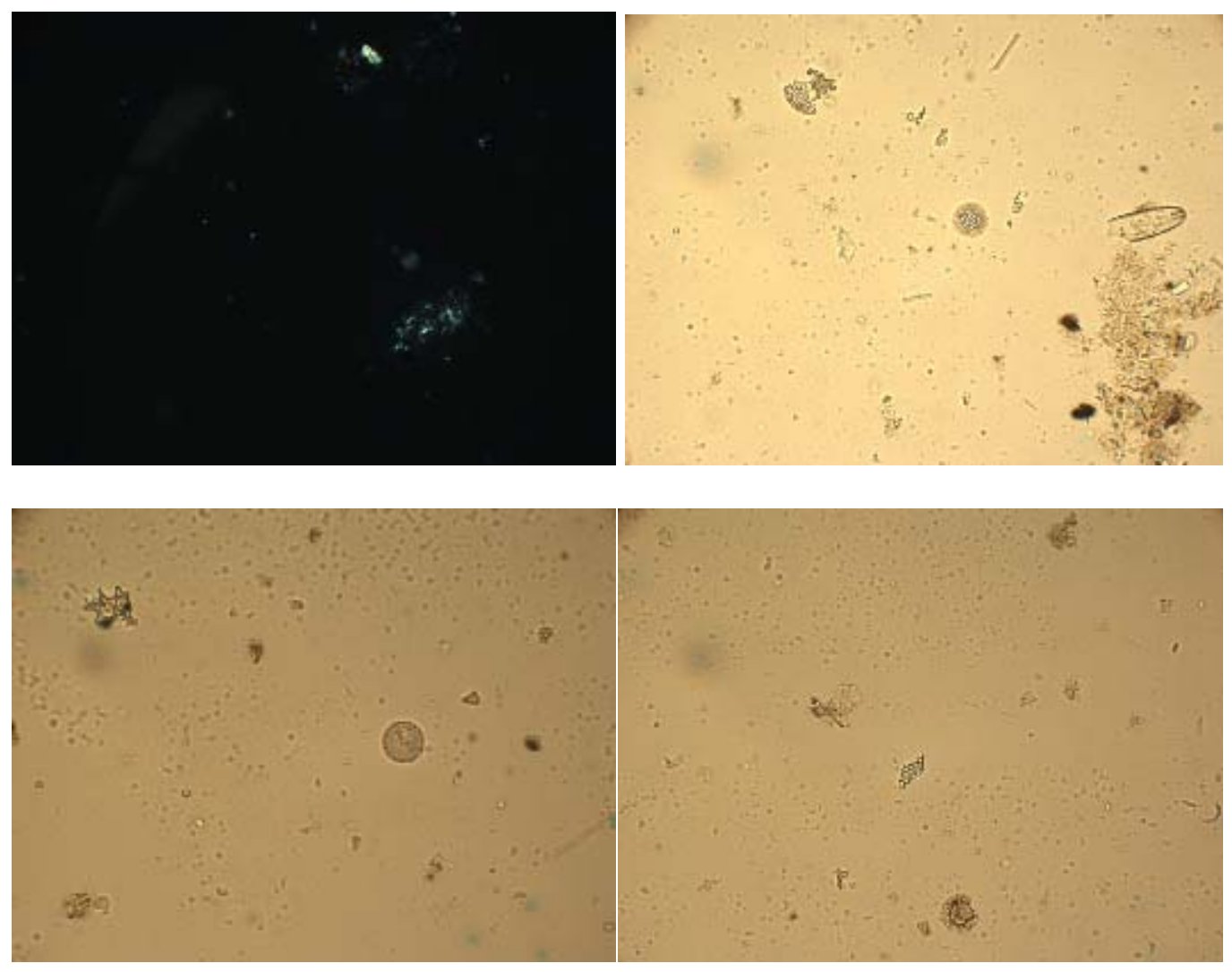

DWBG 115B \#1

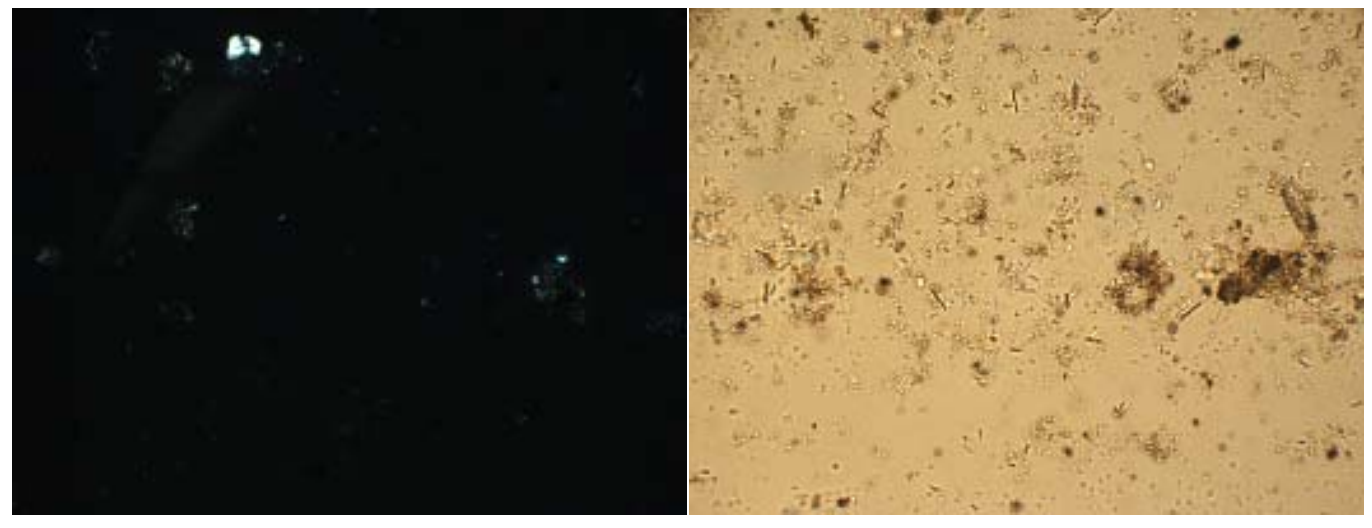

DWHG $79 \# 1$ 


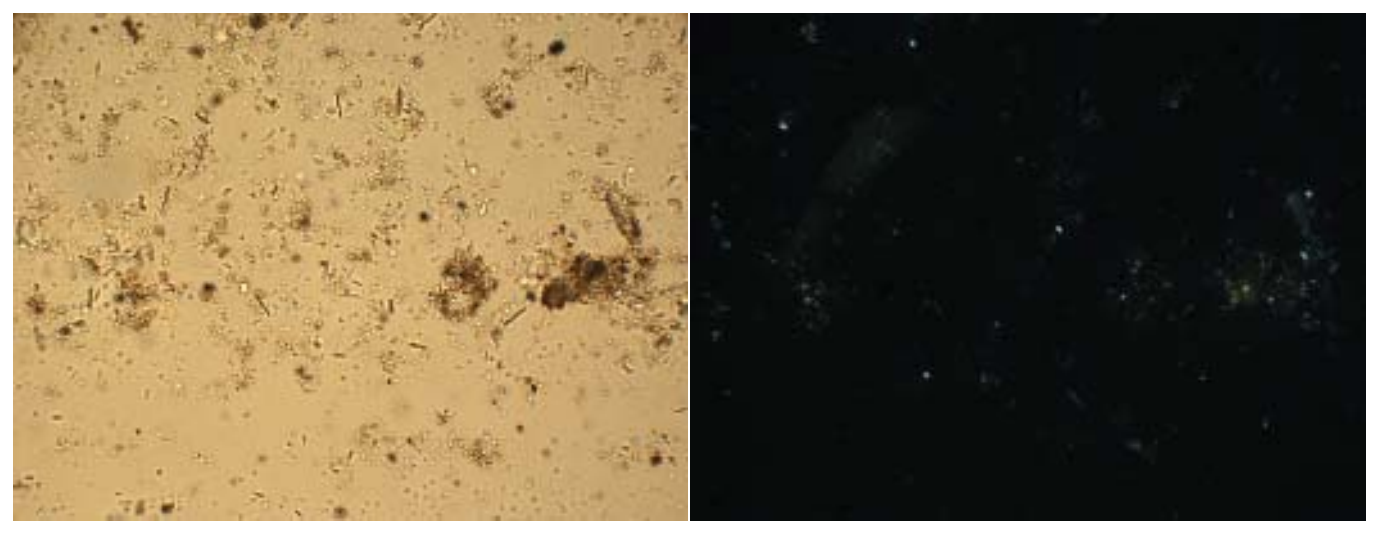

DWBG 97B \#2
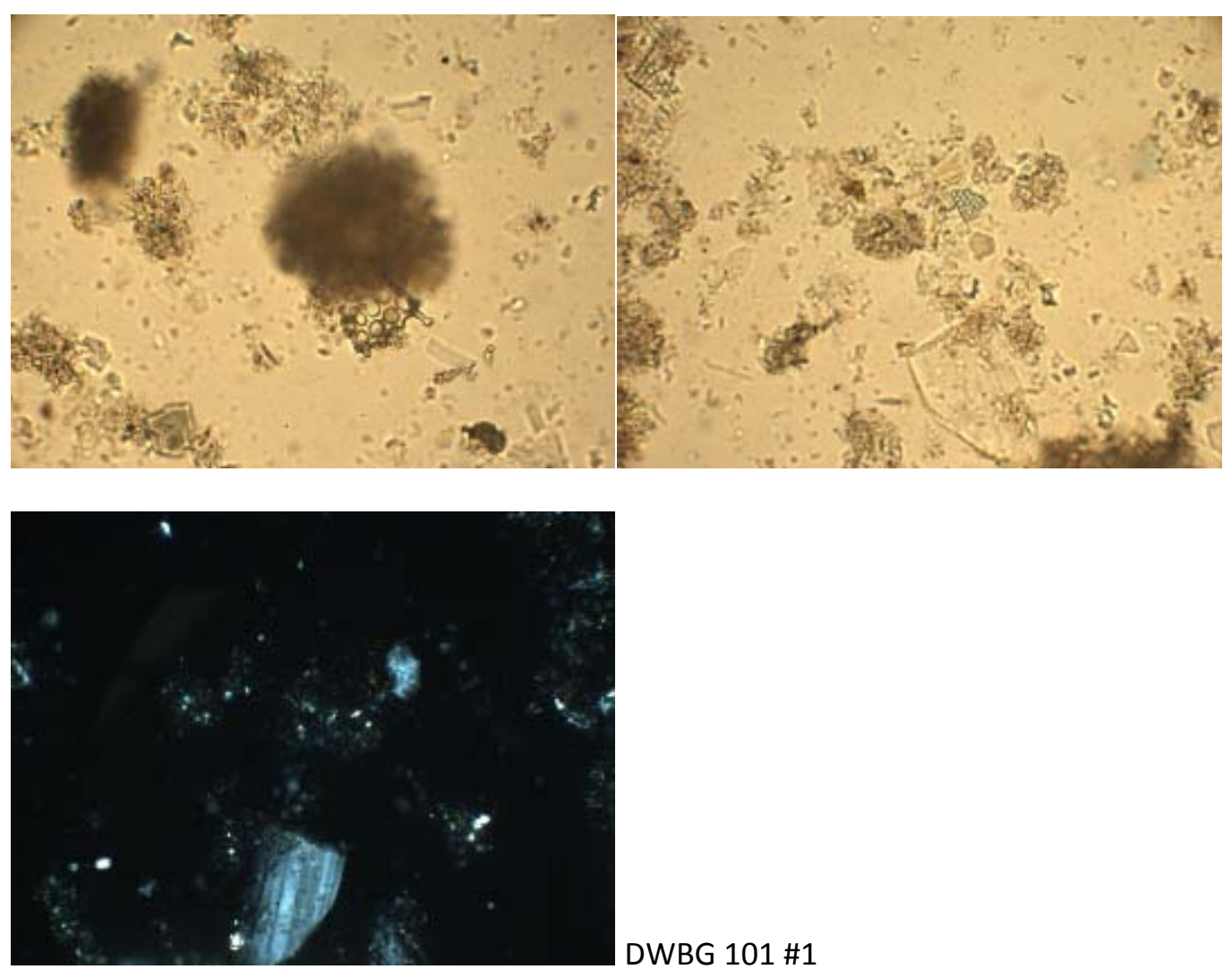


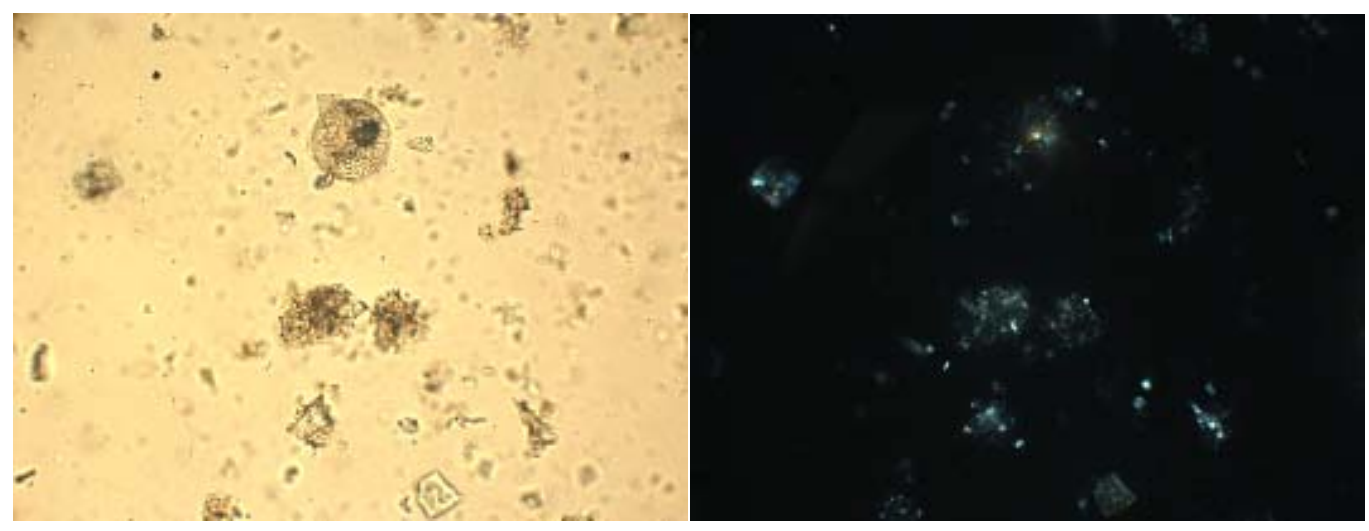

DWBG 101 \#2
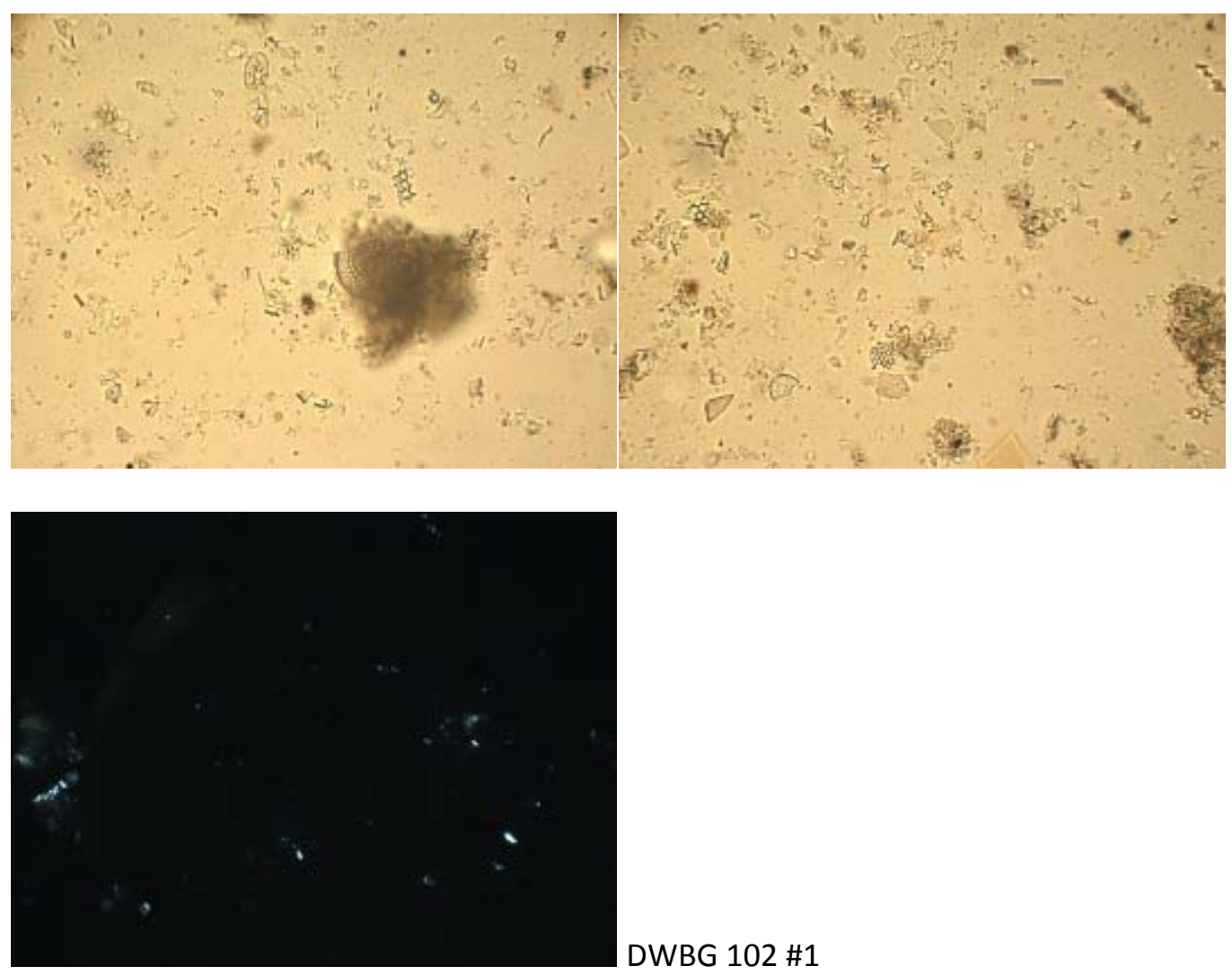

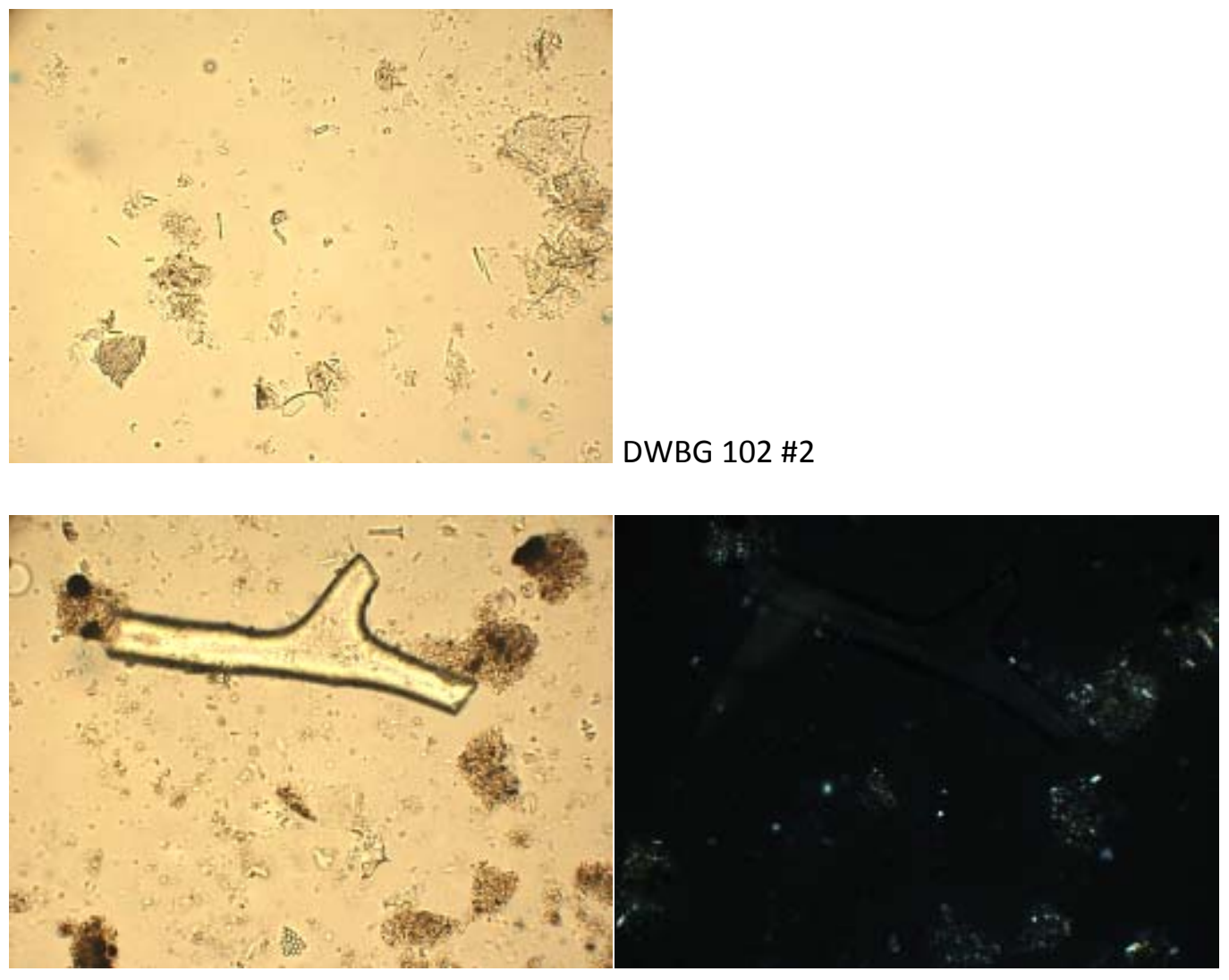

DWBG 115B

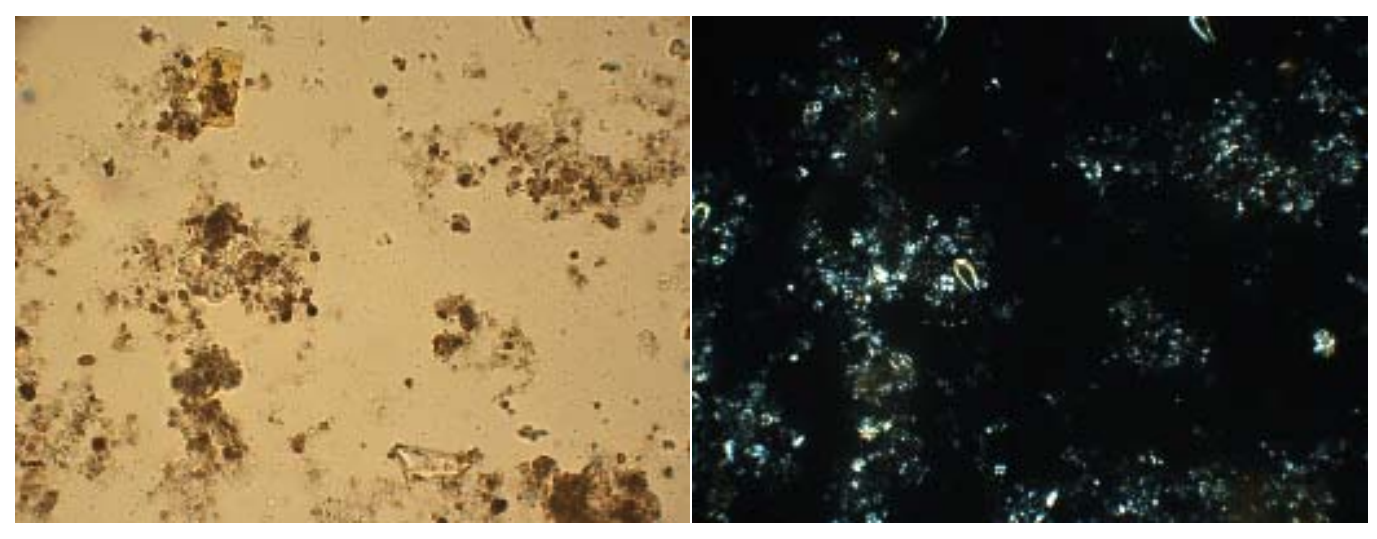

DWBG 117A 


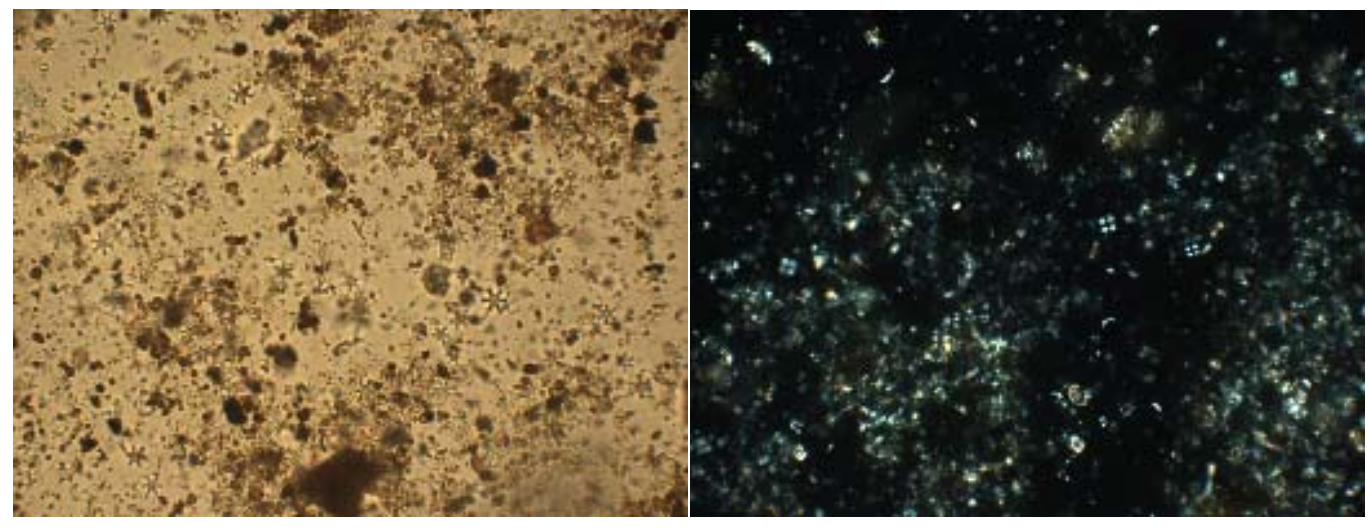

DWBG 118C

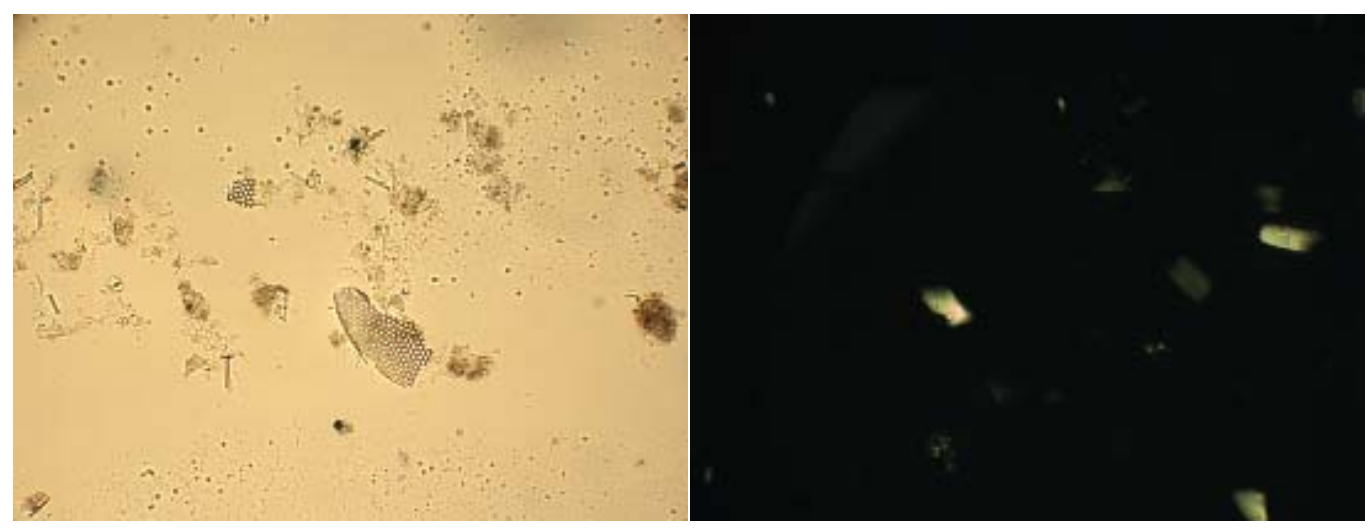

DWBG 109

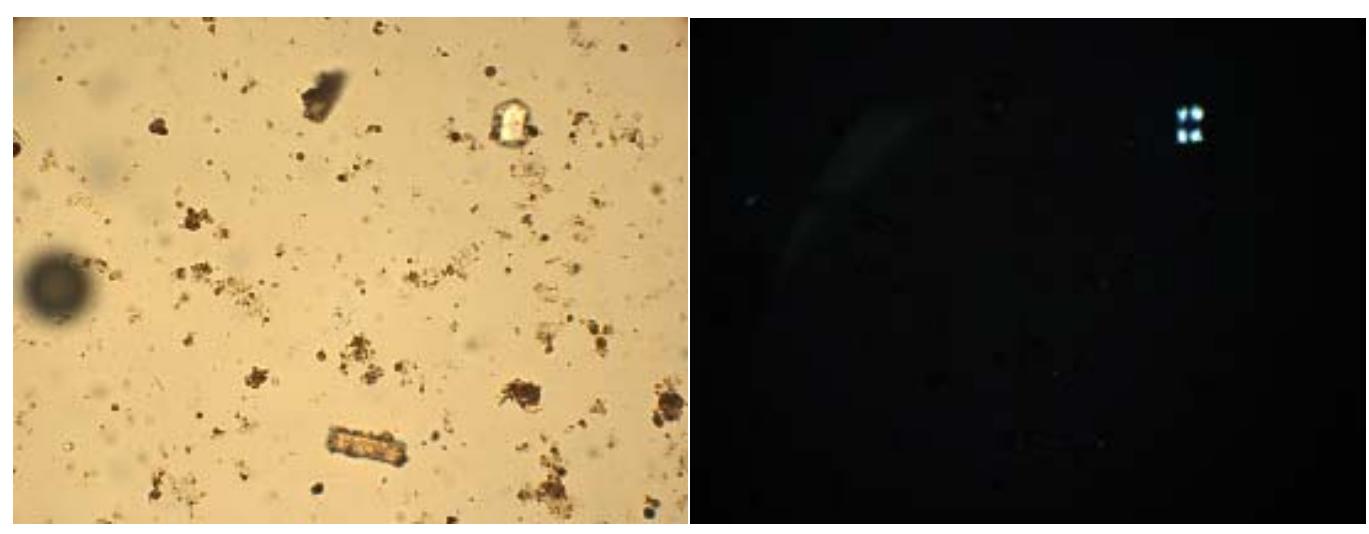

DWHG 56\#2 


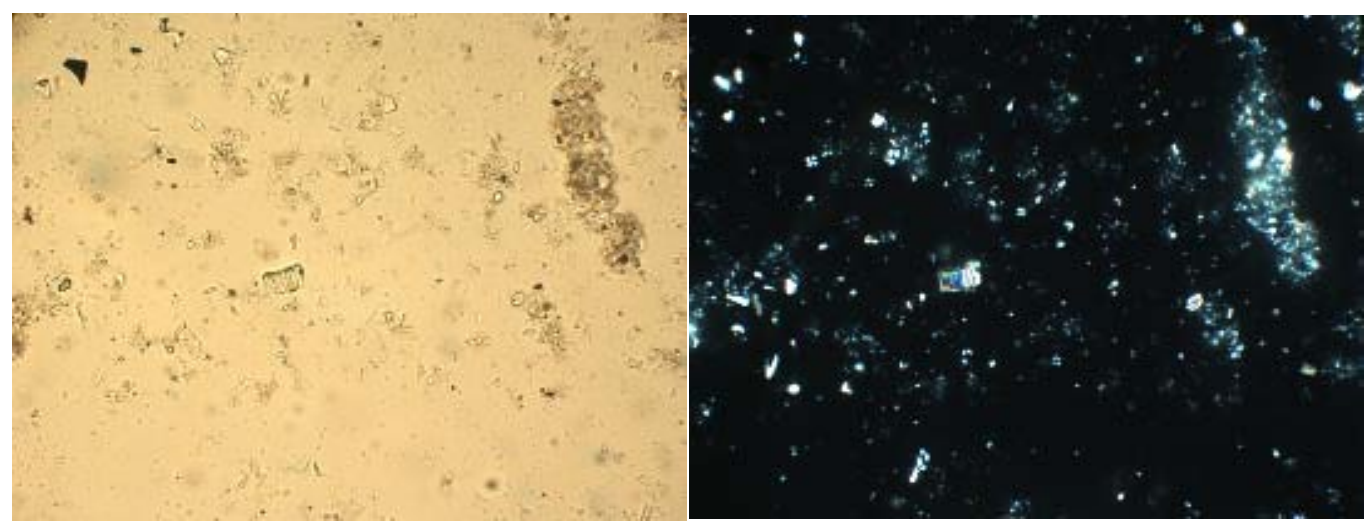

DWHG 69\#2
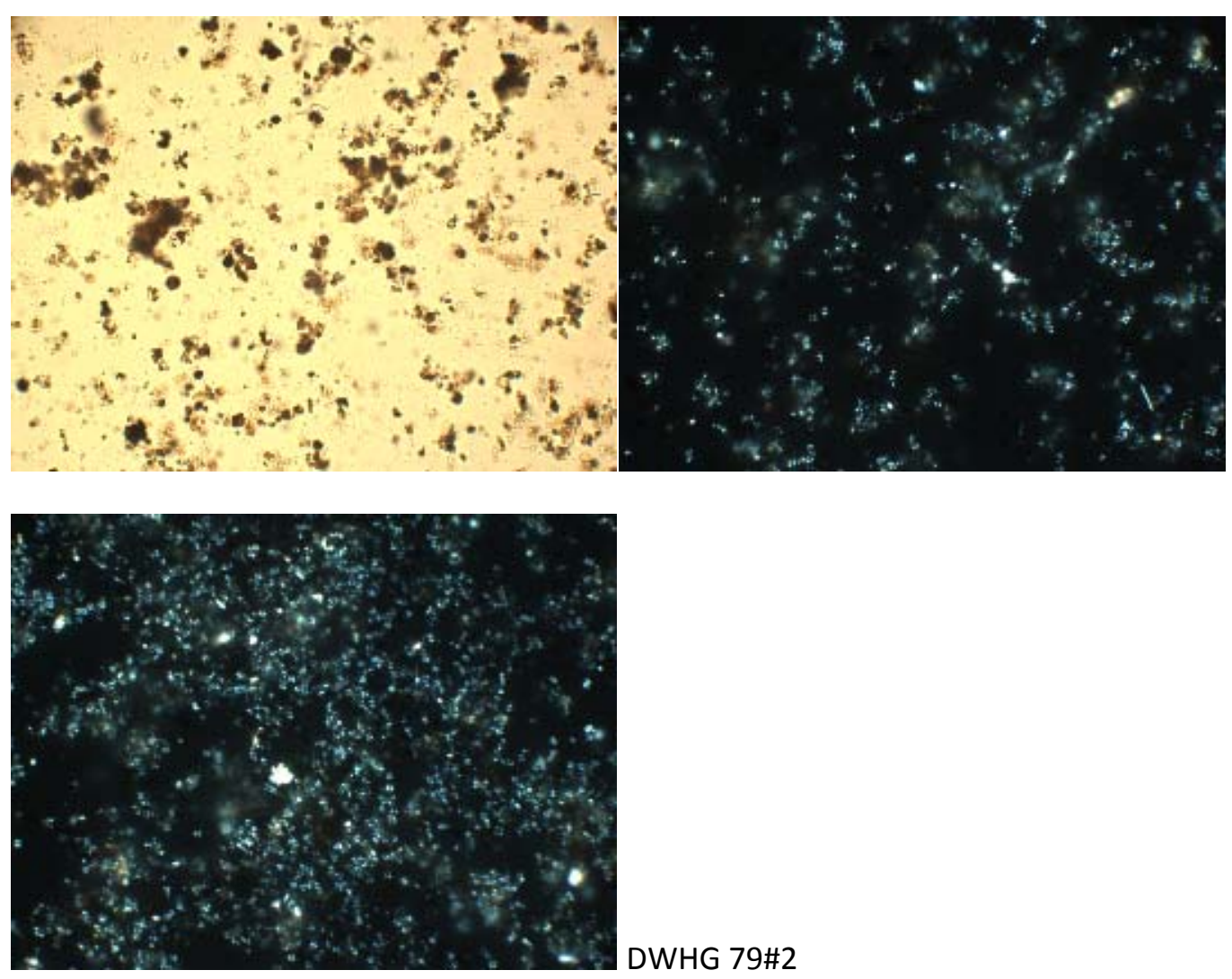

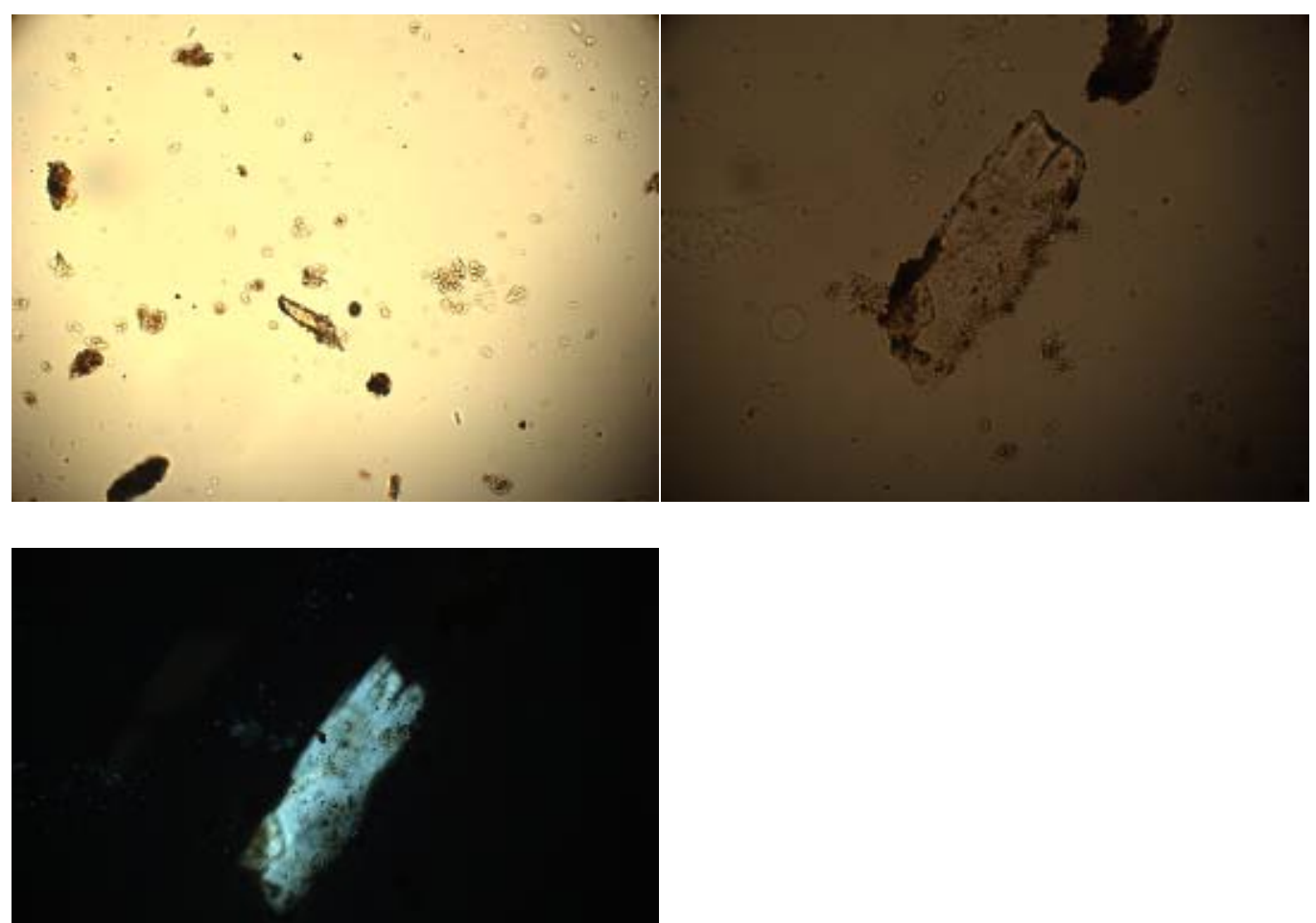

DWHG 56\#1

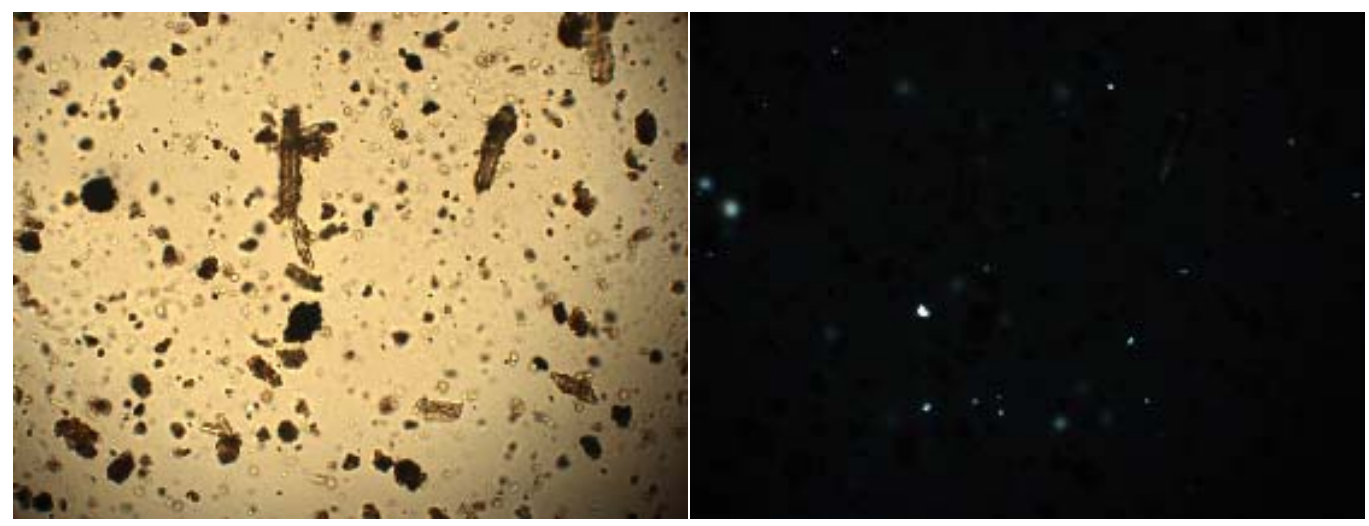

DWHG 54 


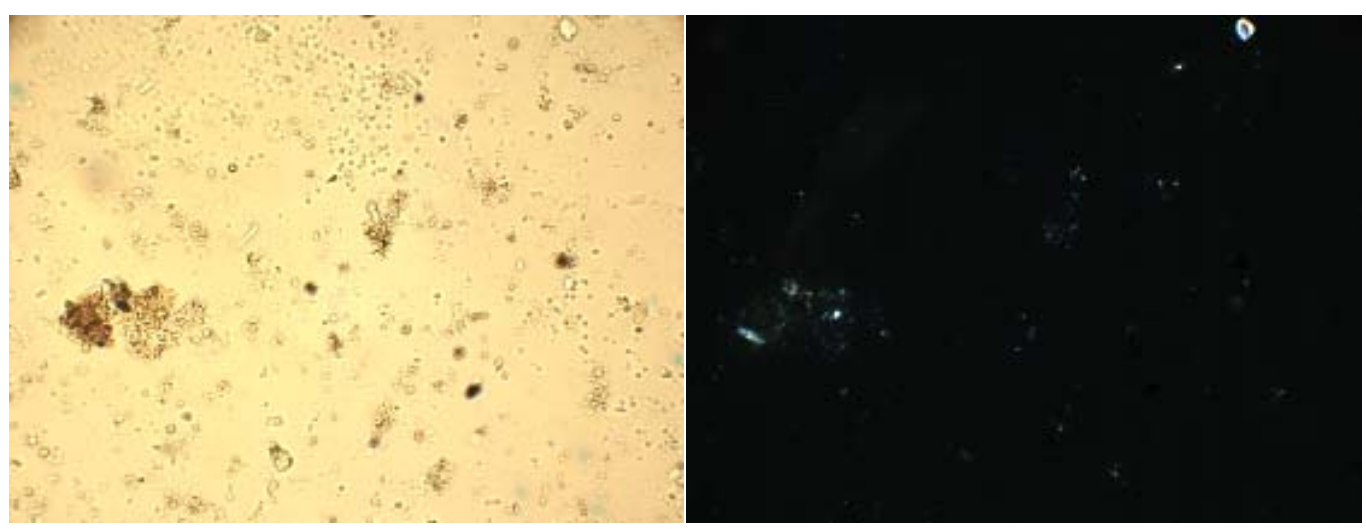

DWHG 67

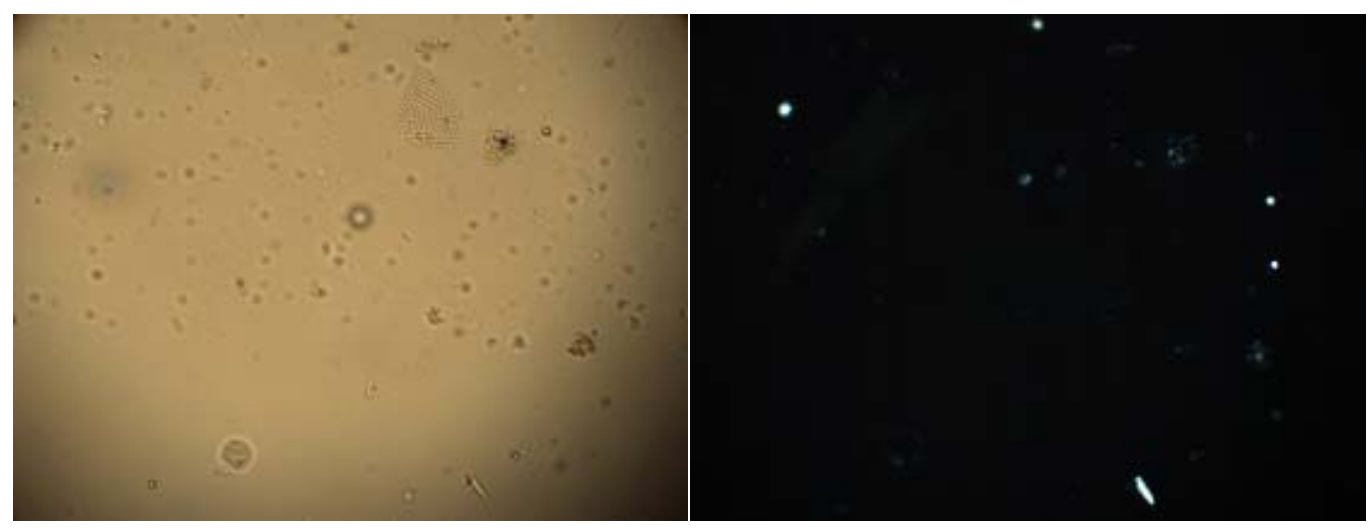

DWHG 69

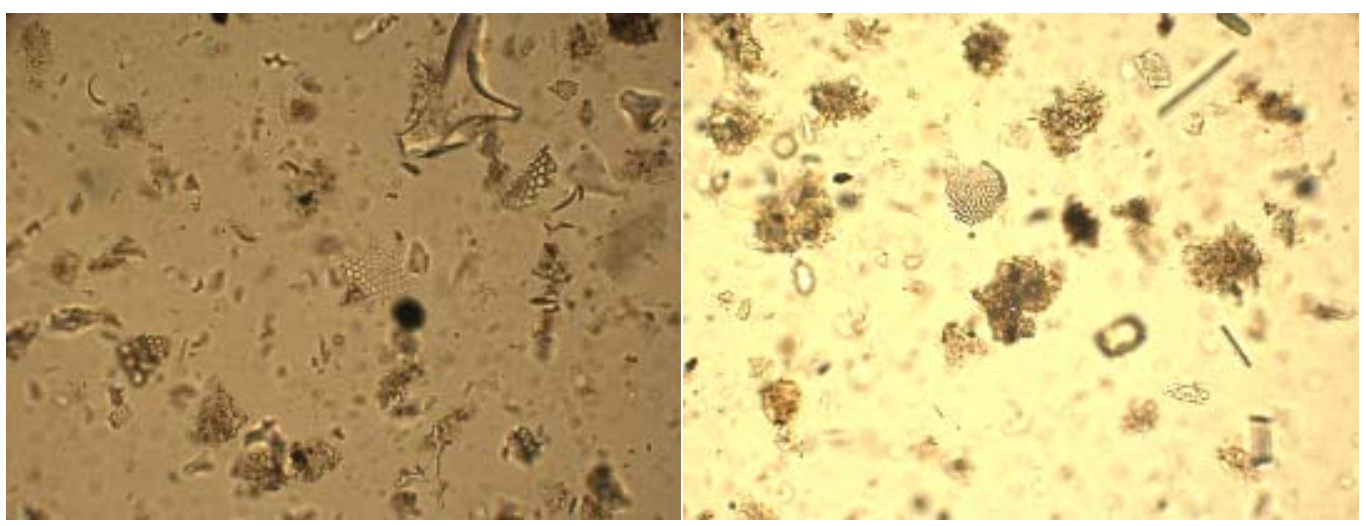



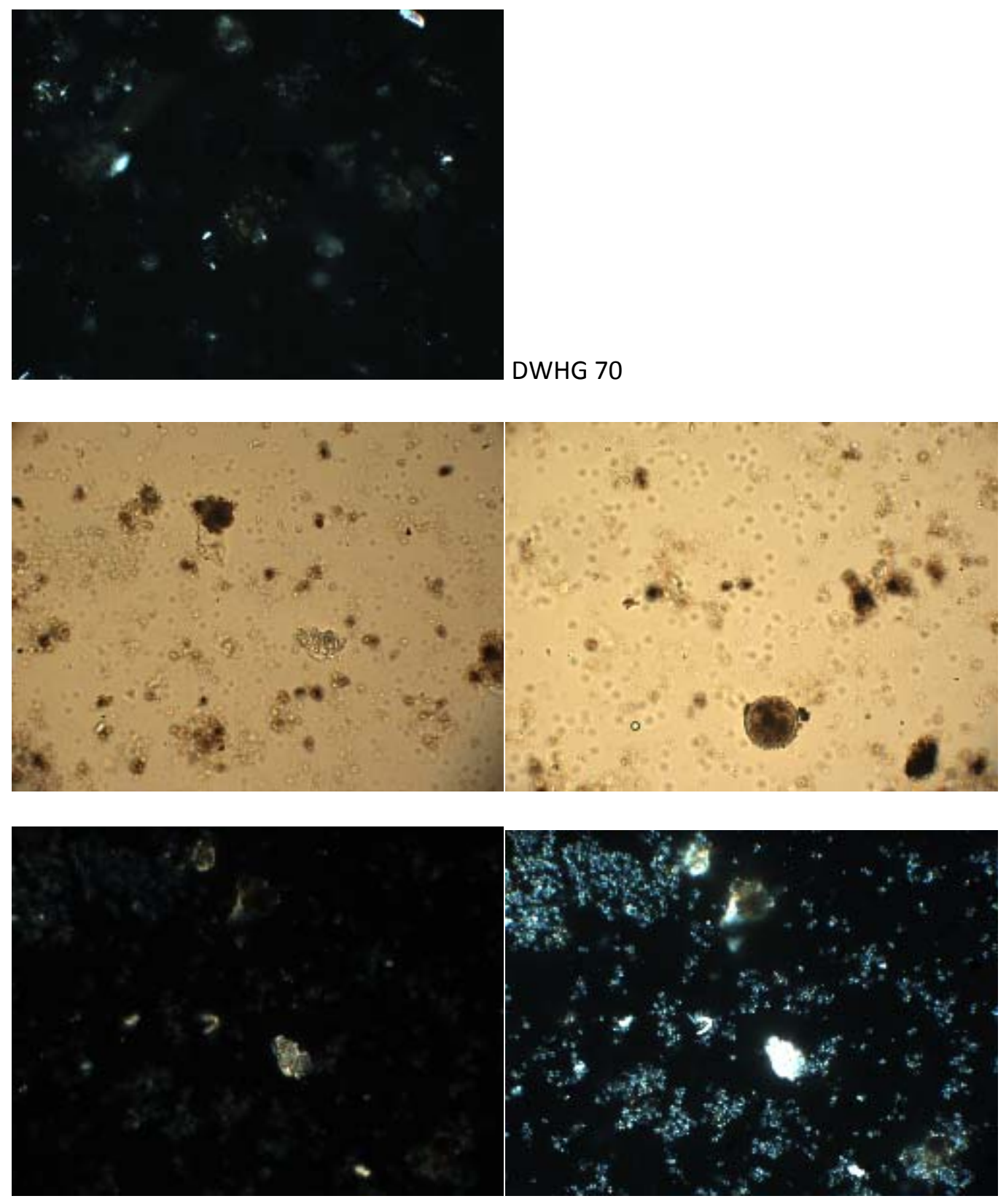

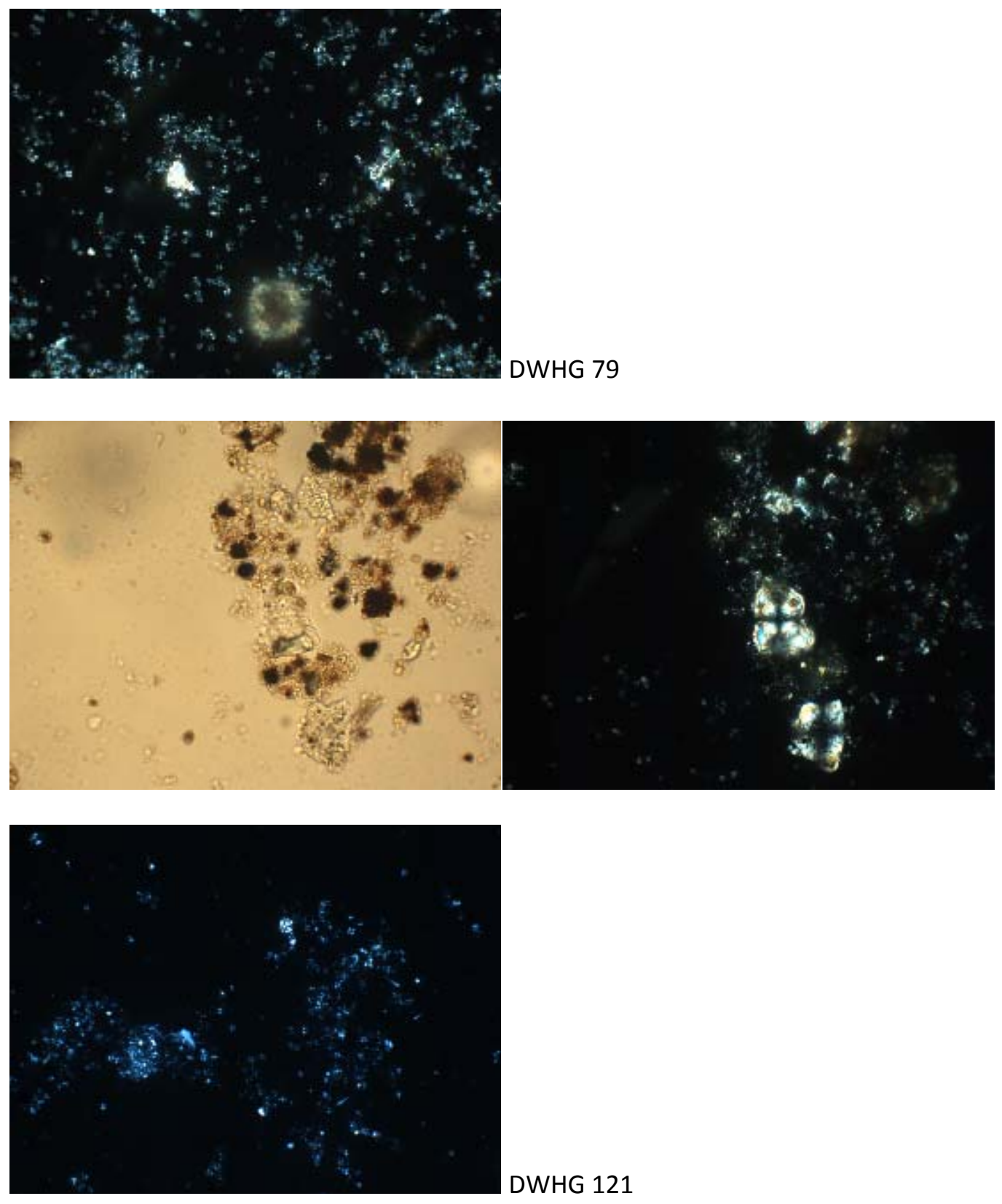


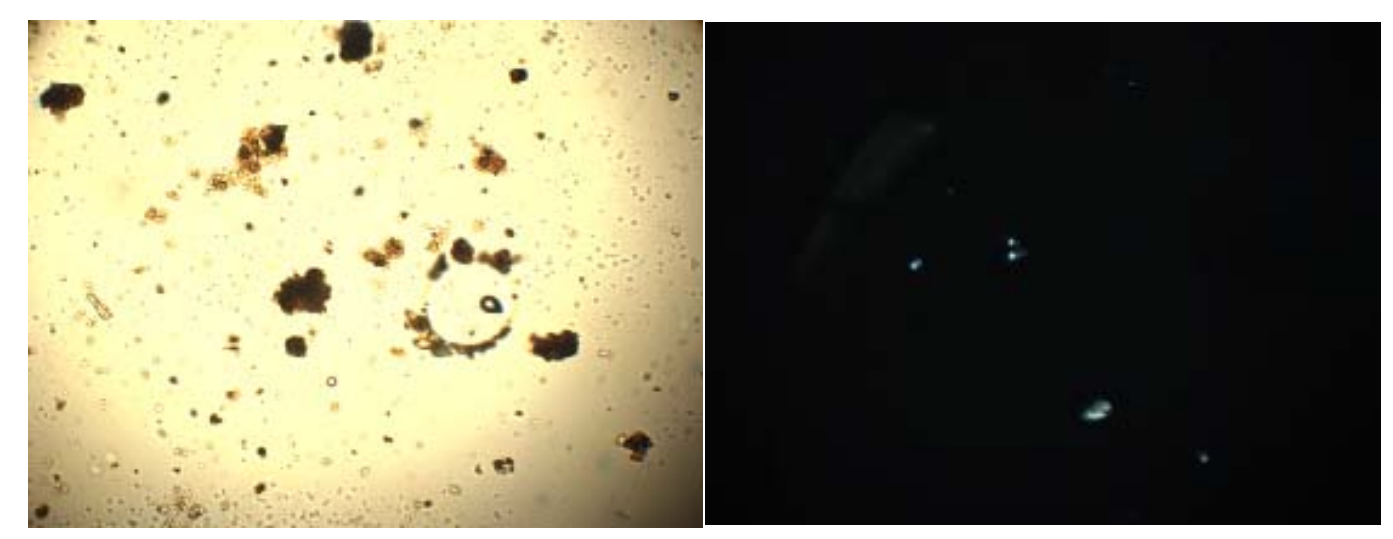

DWHG 56\#2
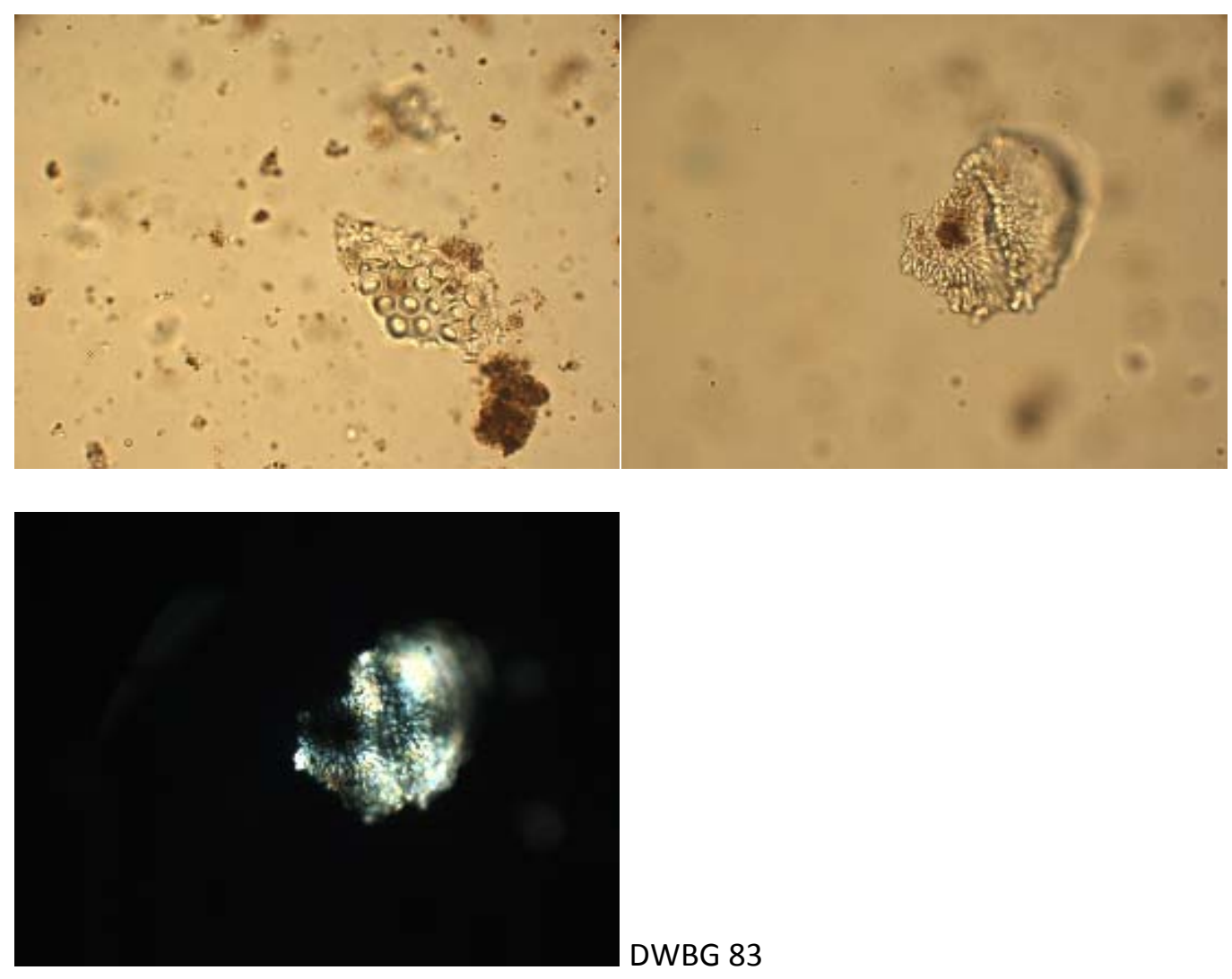


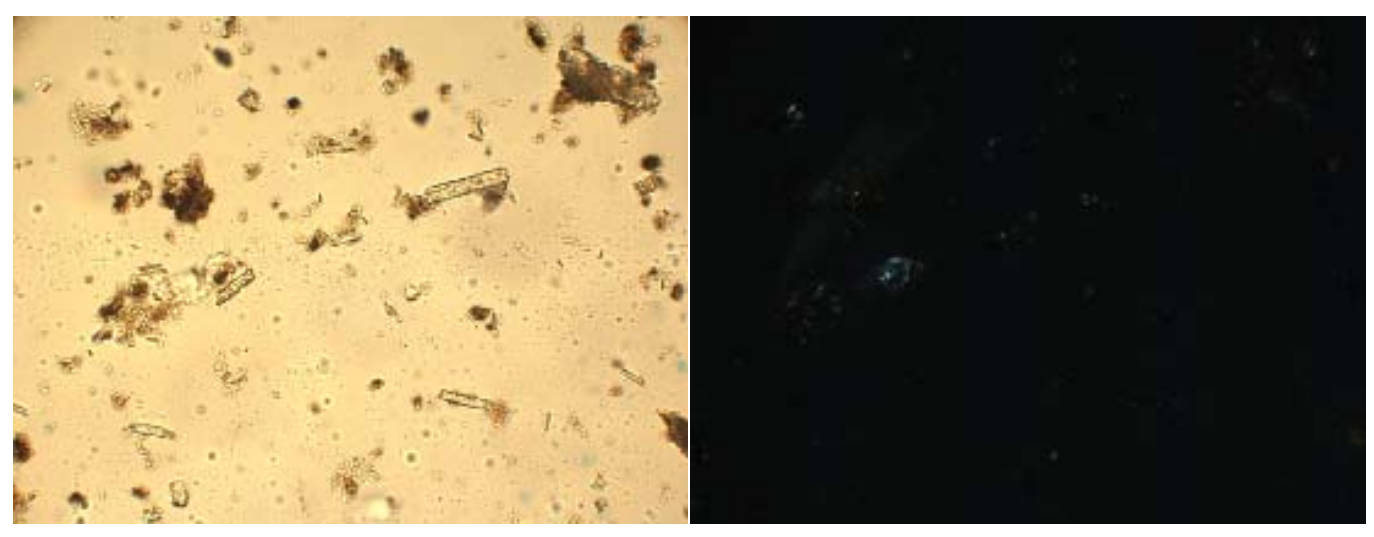

DWHT 49B
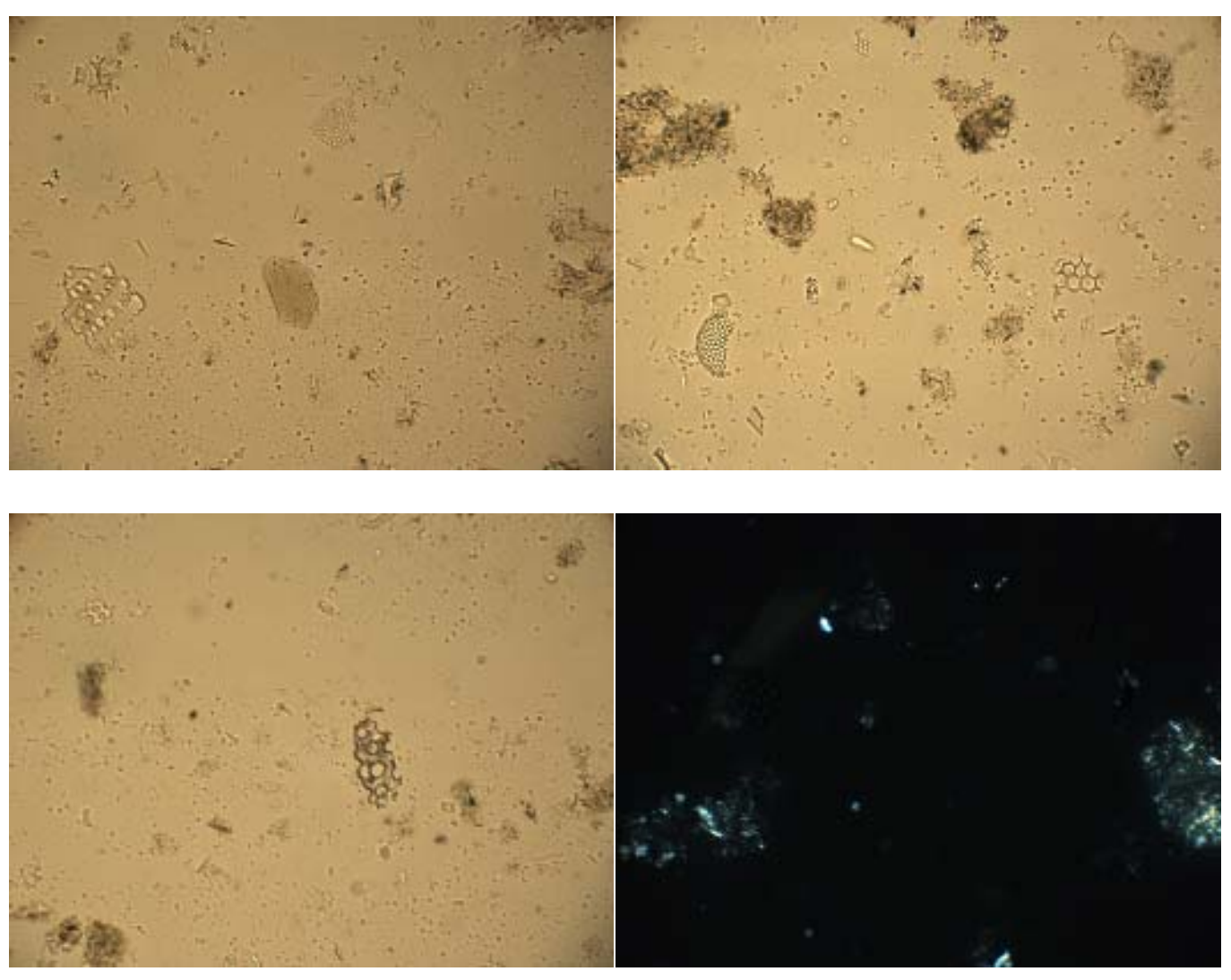

RIS 40G \#1 

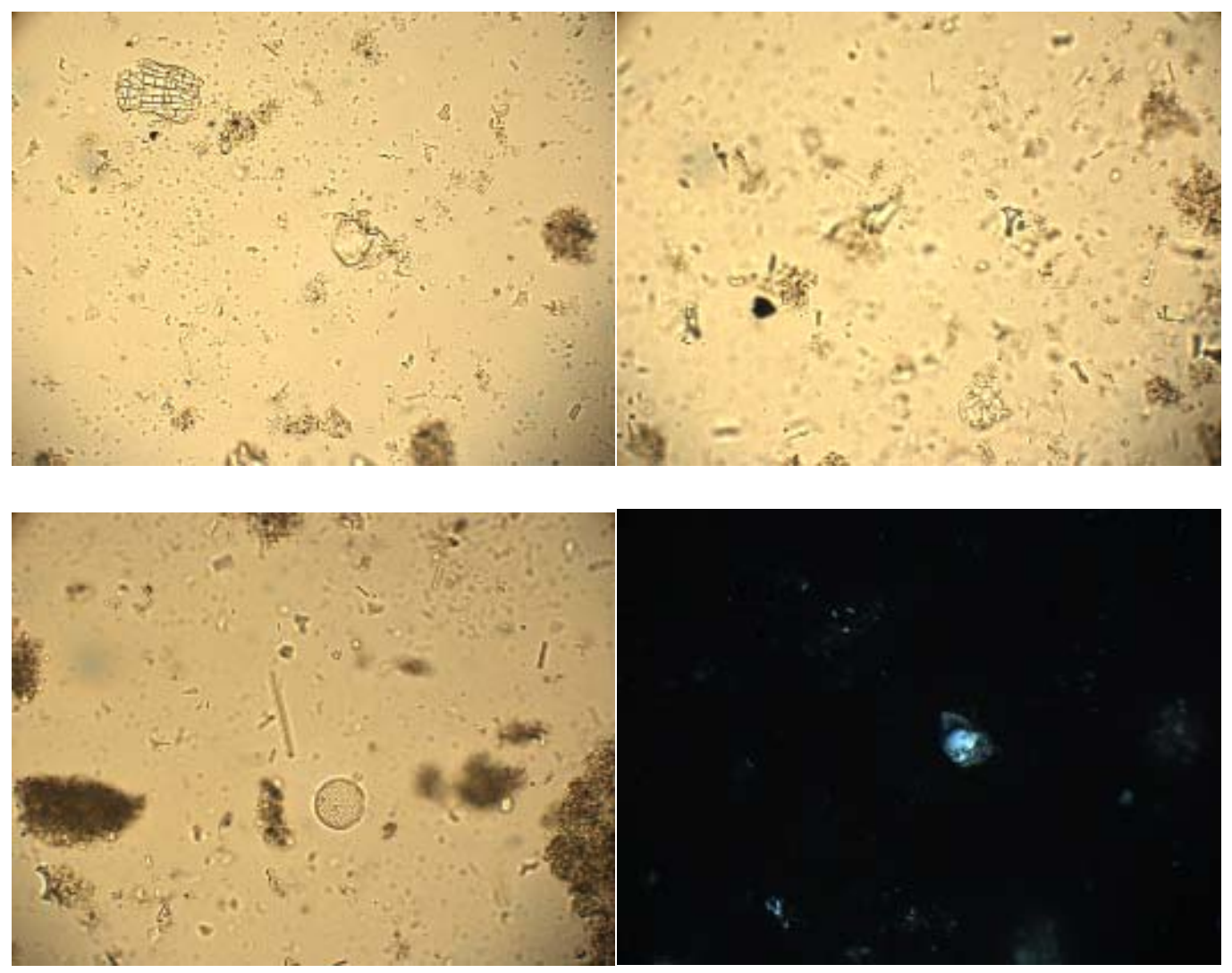

RIS 40G \#2

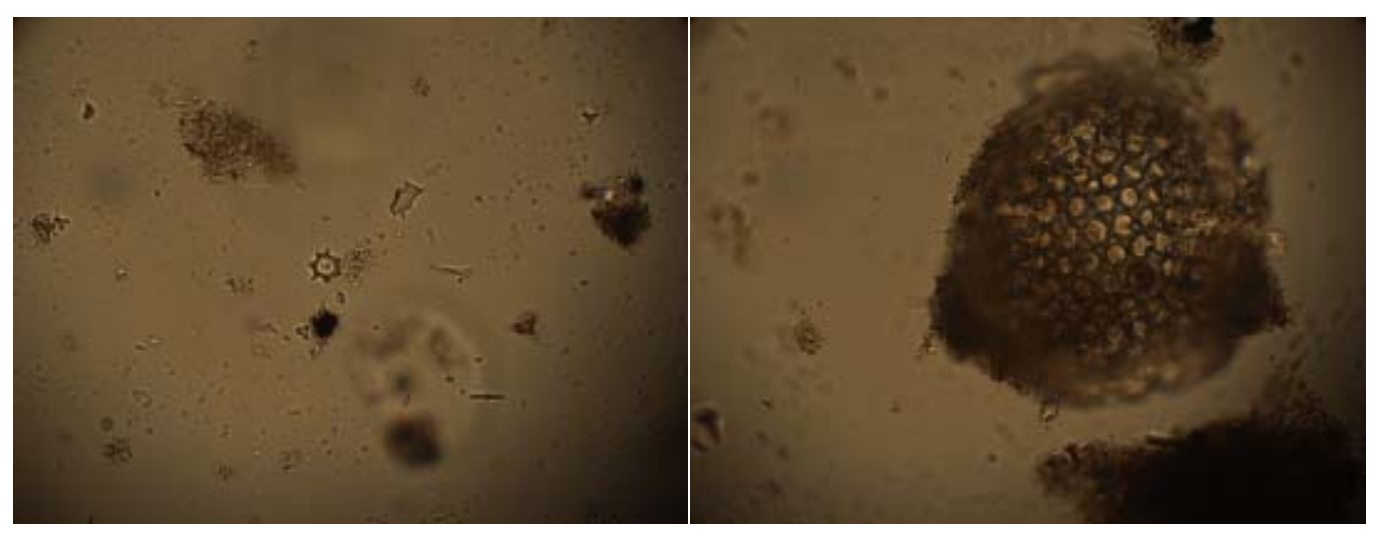



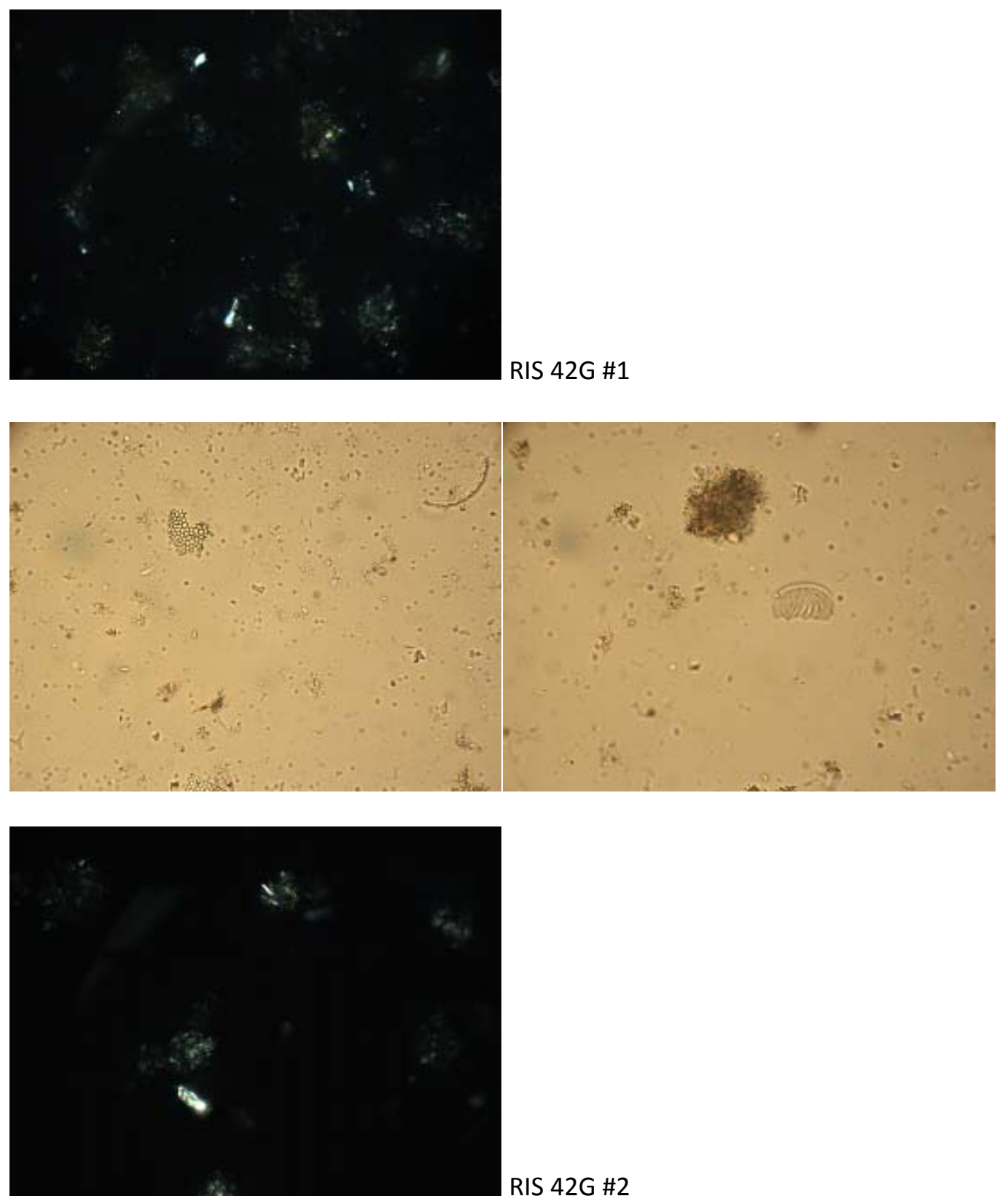

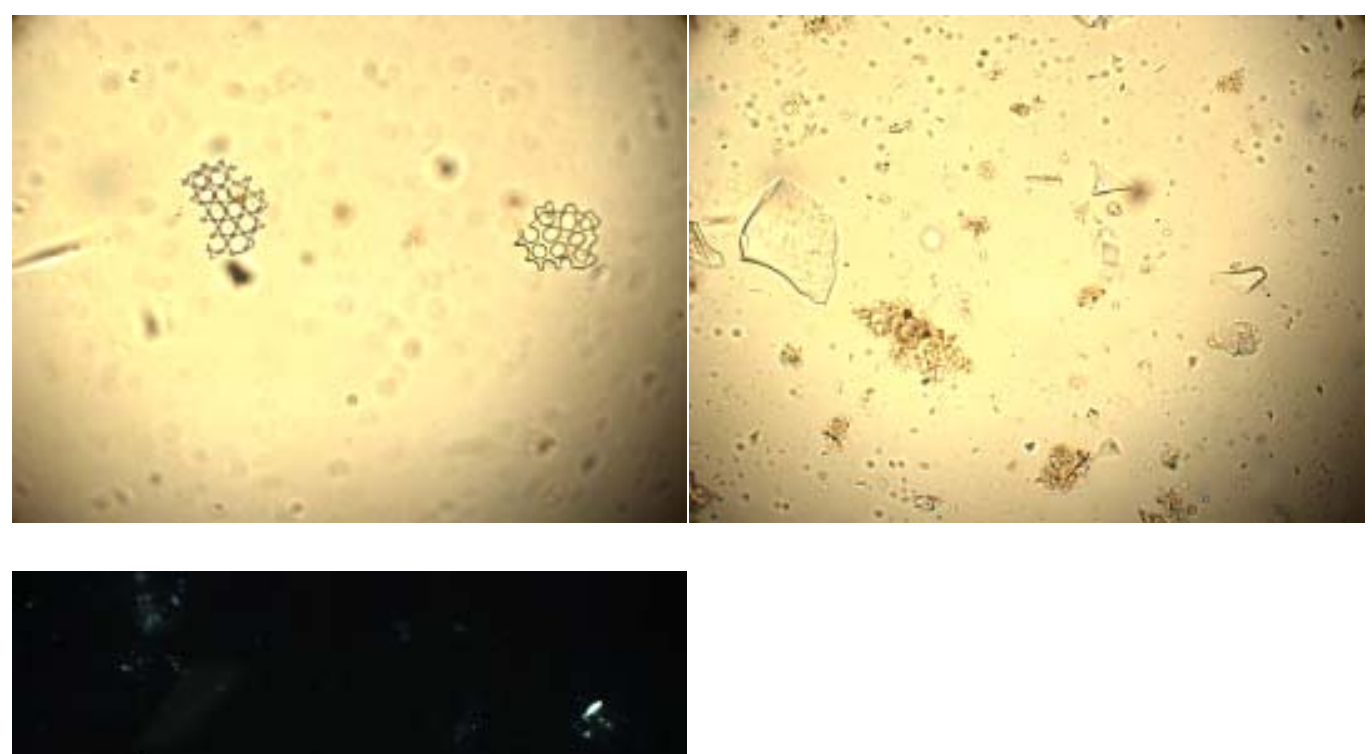

7

RIS 44G \#1

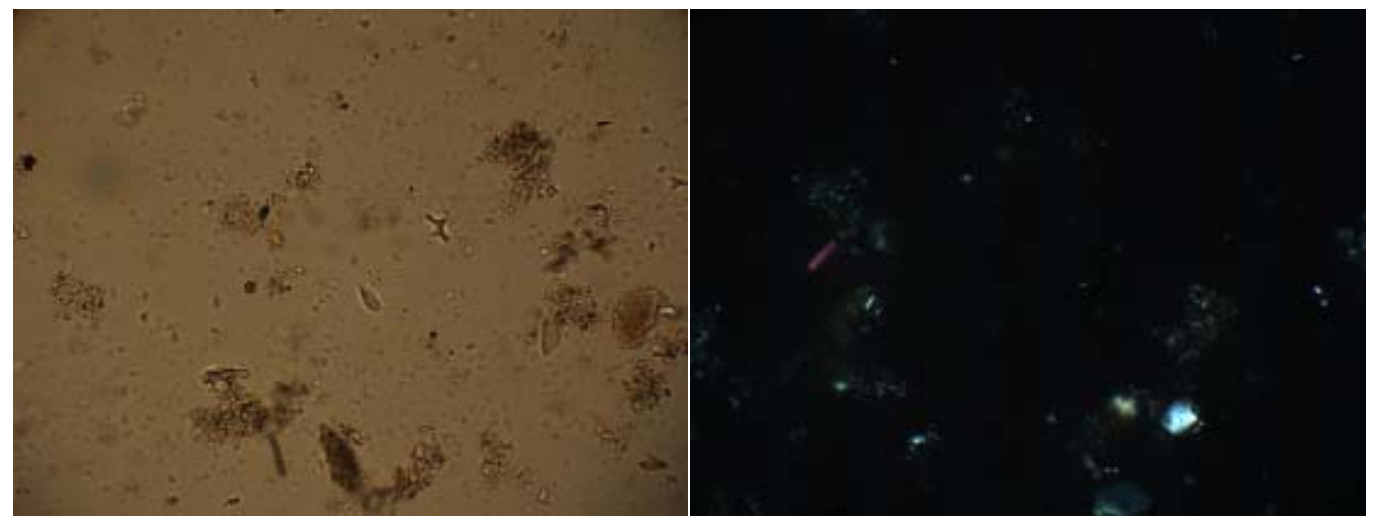

RIS 44G \#2 


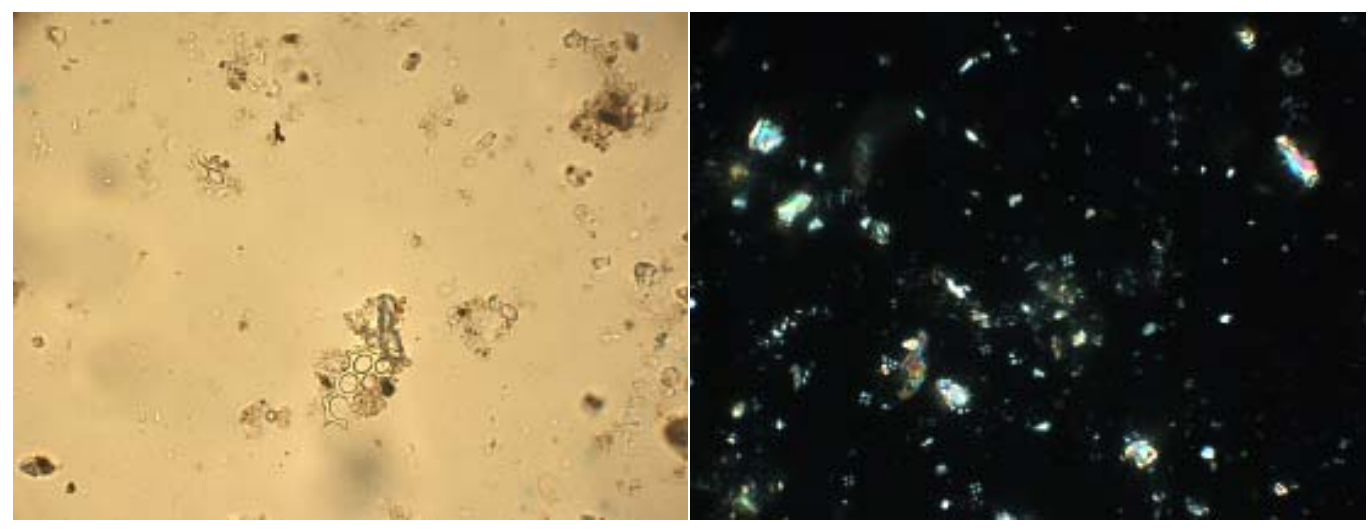

RIS 48G \#1

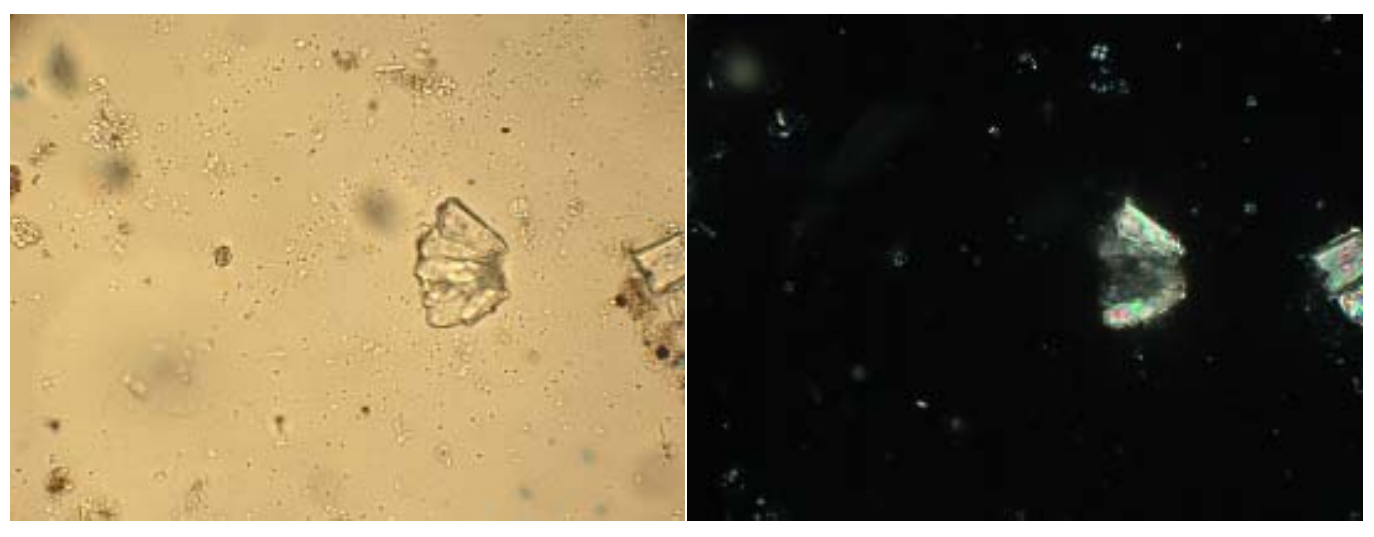

RIS 48G \#2

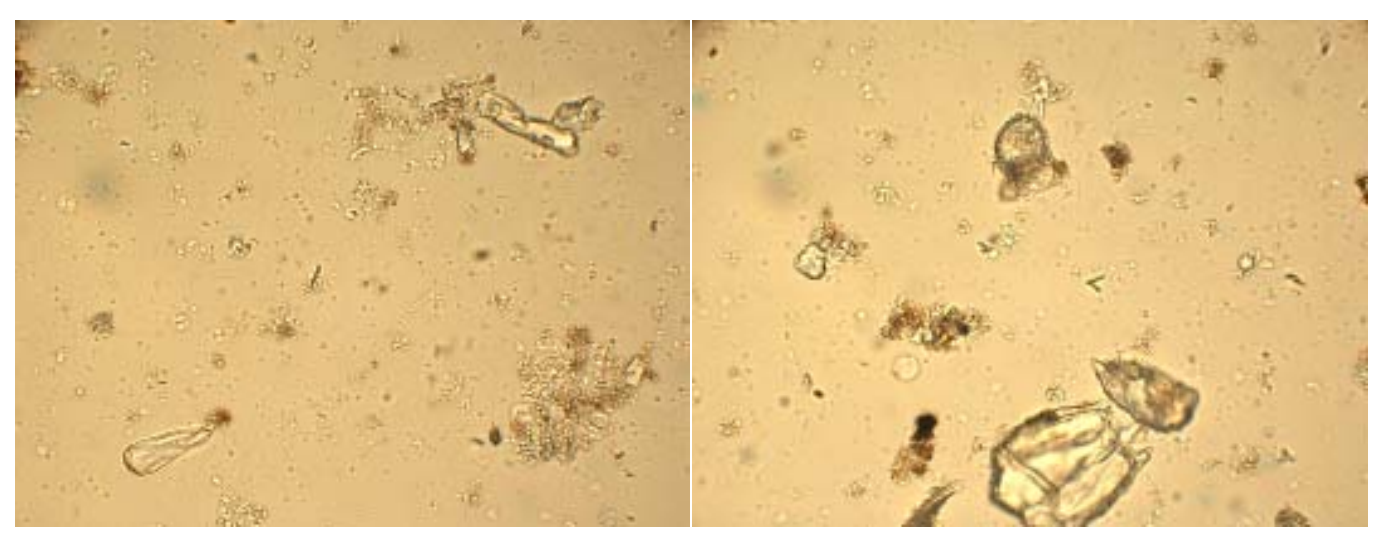




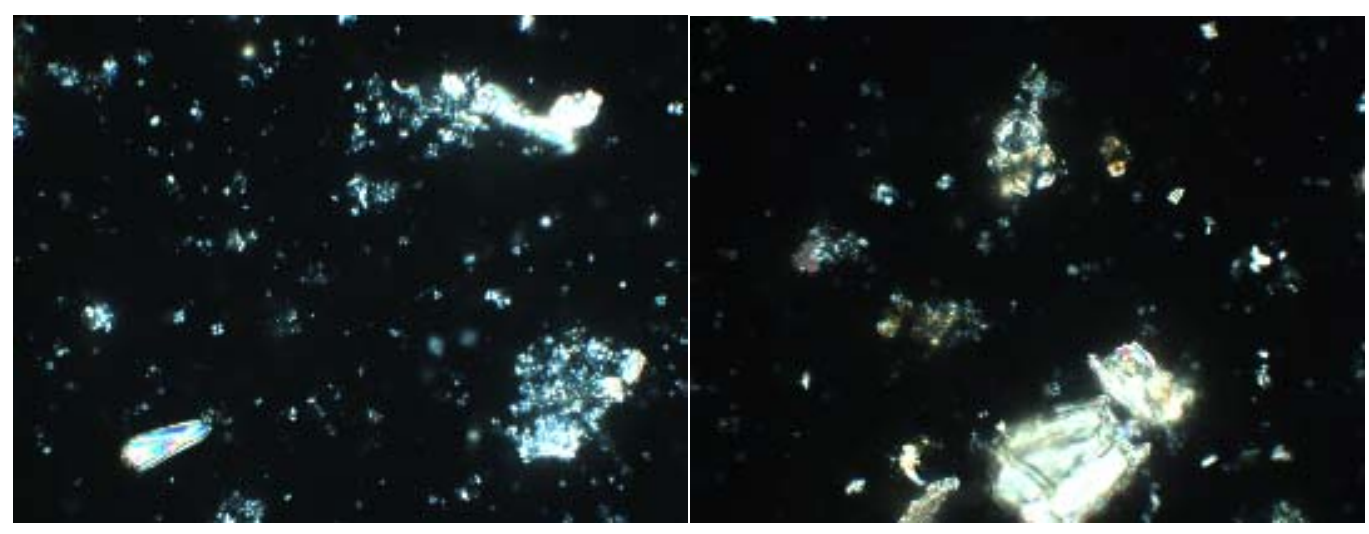

RIS 50G
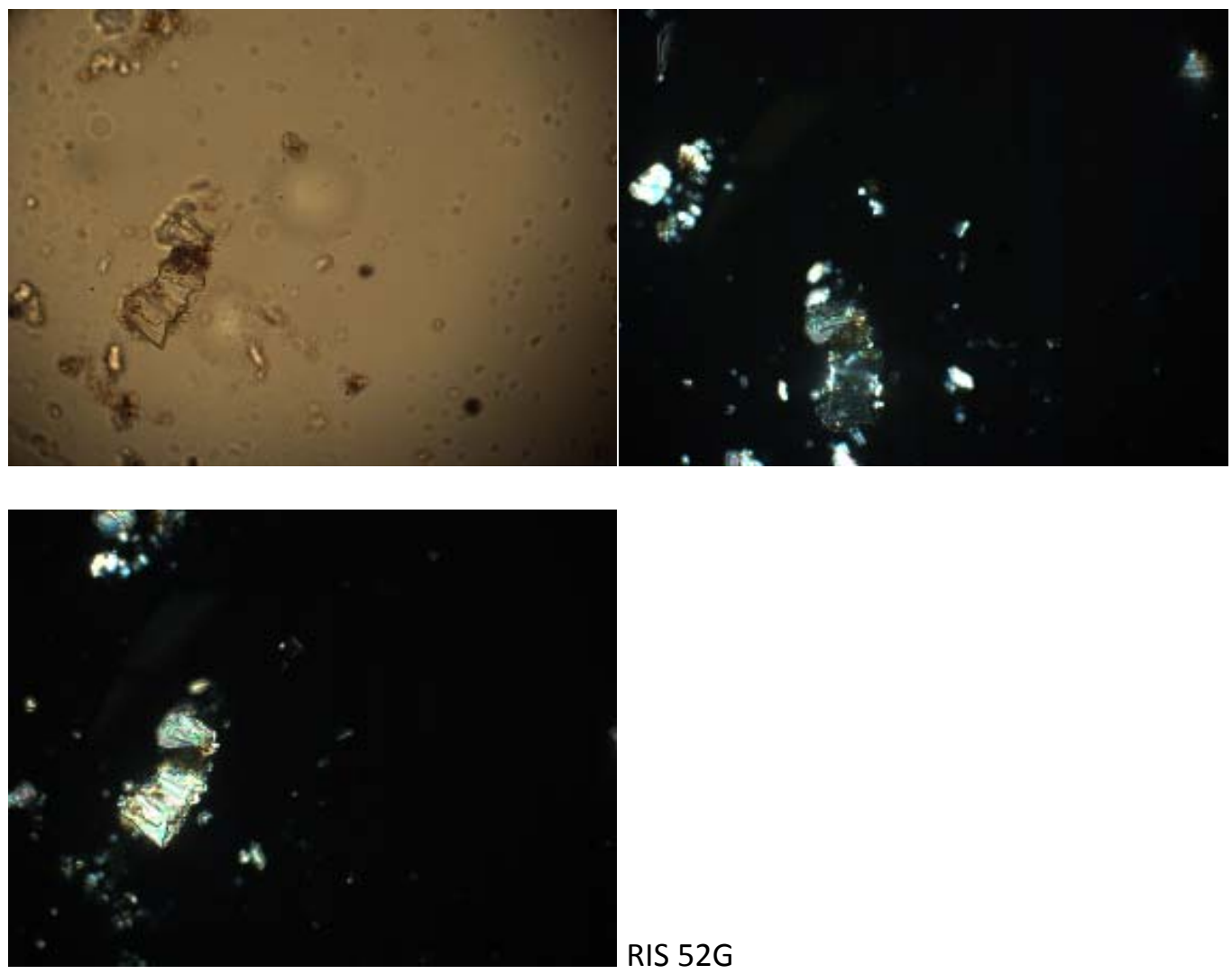